US Army Corps of Engineers ${ }_{\odot}$

Engineer Research and Development Center

\title{
Evaluation of Soil Loss and Erosion Control Measures on Ranges and Range Structures at Installations in Temperate Climates
}

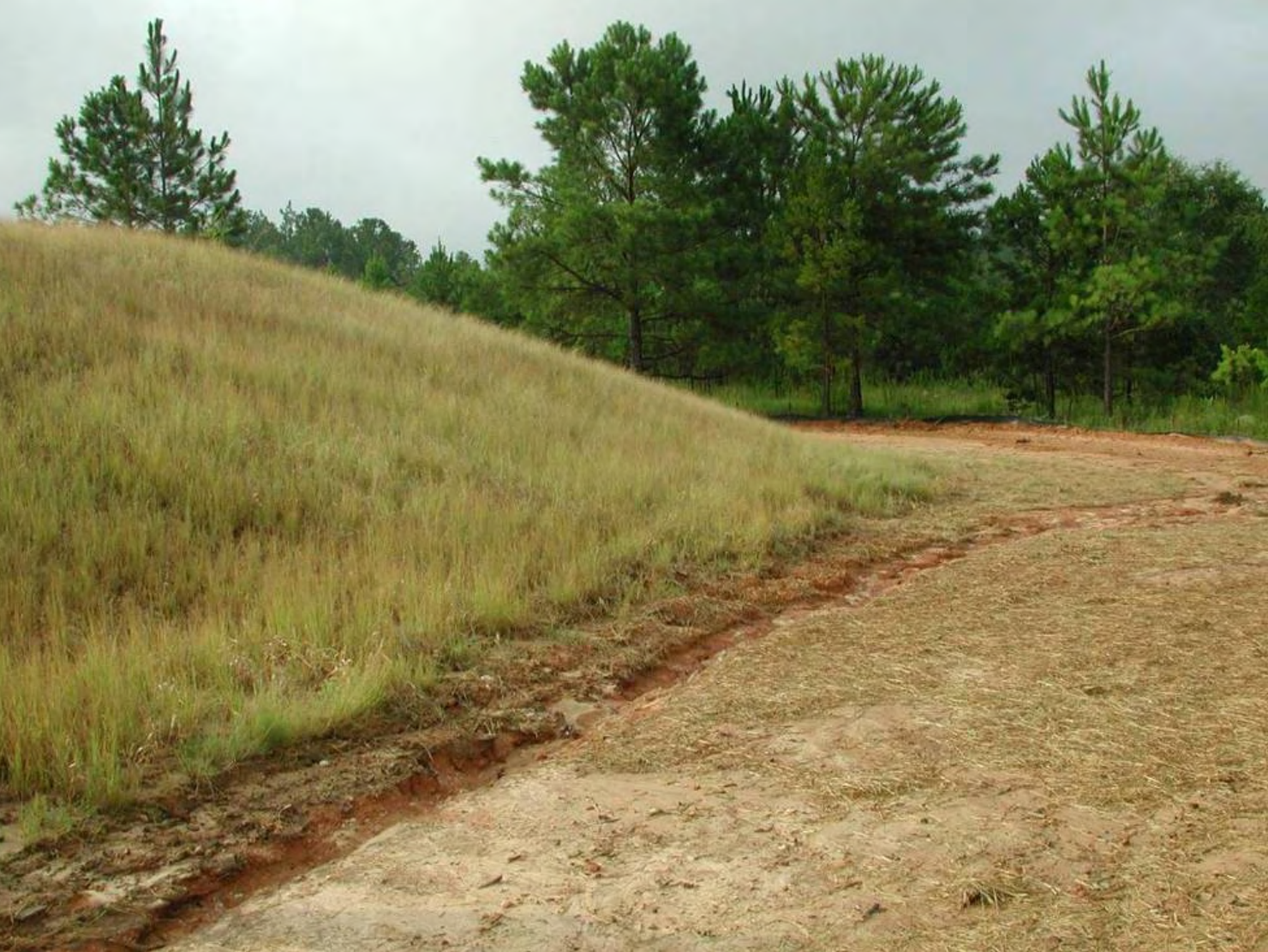




\section{Evaluation of Soil Loss and Erosion Control Measures on Ranges and Range Structures at Installations in Temperate Climates}

Niels G. Svendsen and Dick L. Gebhart

Construction Engineering Research Laboratory

PO Box 9005

Champaign, IL 61826-9005

Prasanta K. Kalita

University of Illinois

Department of Agricultural and Biological Engineering

1304 W. Pennsylvania Ave.

Urbana, IL 61801

Final Report

Approved for public release; distribution is unlimited.

Prepared for U.S. Army Corps of Engineers

Washington, DC 20314-1000

Under

Work Unit \#F50G68 
ABSTRACT: The Department of Defense operates the largest and most diverse training enterprise in the world. The Army has under its authority 1.3 million uniformed and civilian personnel at over 4100 locations using over 61 million square kilometers of land. Providing realistic and effective training is a key element in fulfilling the military mission. The sustainable use of military training lands presents a challenge to maintaining combat preparedness. Range managers need cost-effective long-term solutions that alleviate maintenance requirements and increase training intervals.

Guidelines on the design of small arms ranges to prevent erosion have been developed. However, these guidelines do not incorporate sustainable range elements into the overall design, and without proper soil and water conservation, large ranges have the potential to contribute greatly to overall installation erosion.

This research evaluates design weaknesses and develops an improved design methodology for embankments, firing points, and targeting impact positions on training ranges. Additionally recommendations are outlined that propose specific guidelines for range structures: defilades, stationary armor targets and moving armor targets that reduce soil loss and improve training realism.

DISCLAIMER: The contents of this report are not to be used for advertising, publication, or promotional purposes. Citation of trade names does not constitute an official endorsement or approval of the use of such commercial products. All product names and trademarks cited are the property of their respective owners. The findings of this report are not to be construed as an official Department of the Army position unless so designated by other authorized documents. 


\section{Contents}

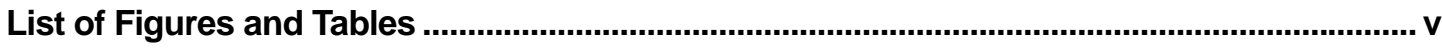

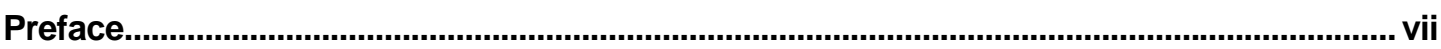

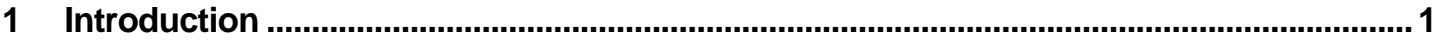

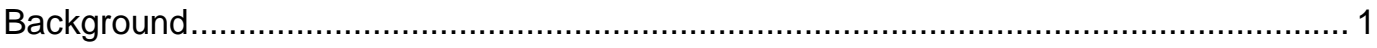

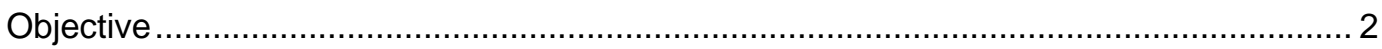

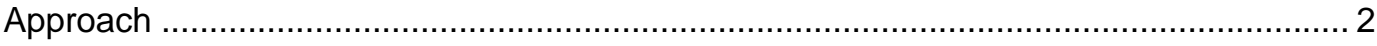

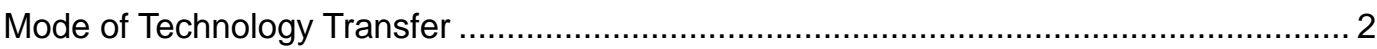

2 Installation Range Evaluation Visits......................................................................... 3

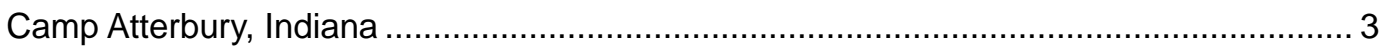

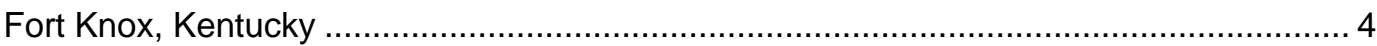

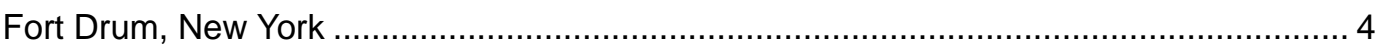

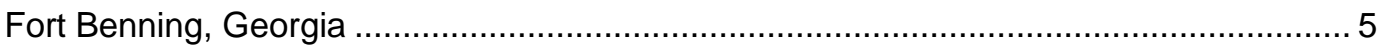

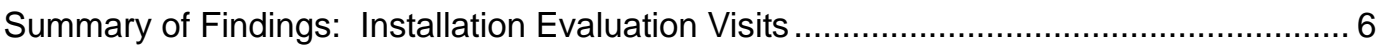

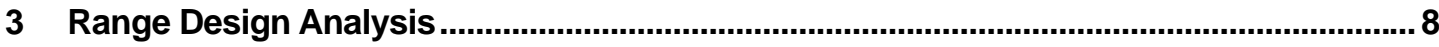

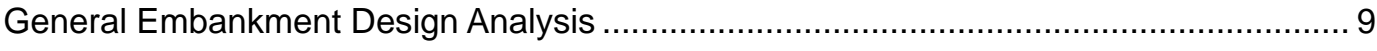

Target and Firing Emplacement Design Analysis ............................................ 10

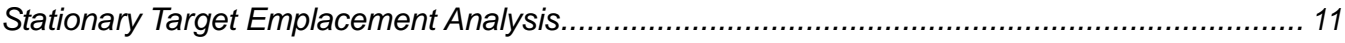

Moving Target Embankments Analysis ................................................................ 15

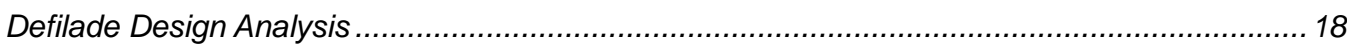

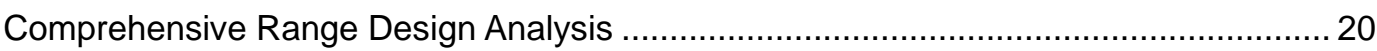

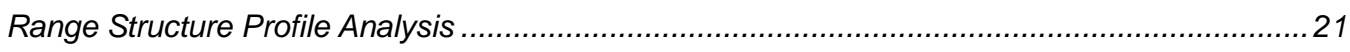

Soil and Water Conservation Implementation Analysis ..............................................22

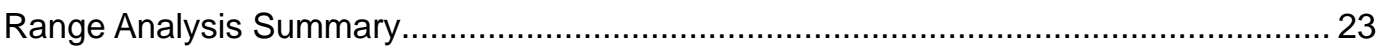

4 Range Monitoring Case Study: Camp Atterbury, Indiana ................................................25

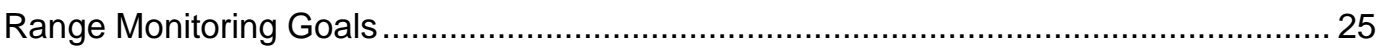

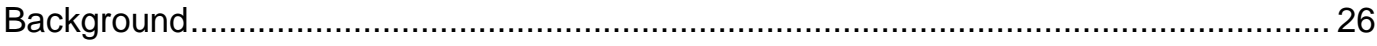

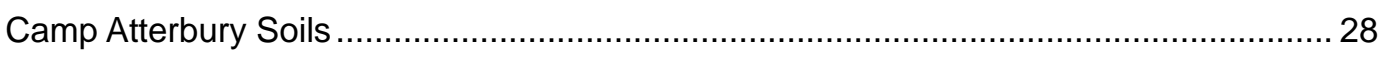

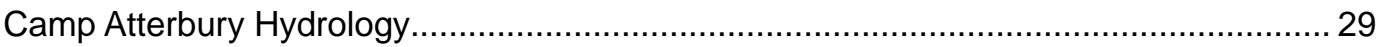

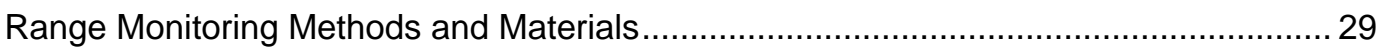

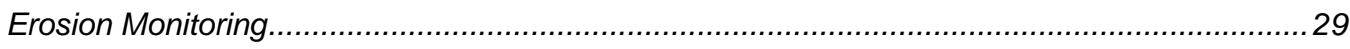

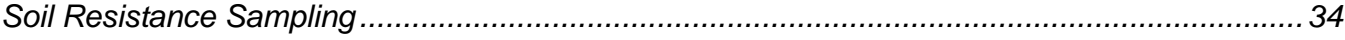




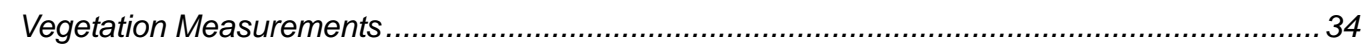

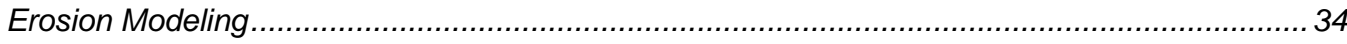

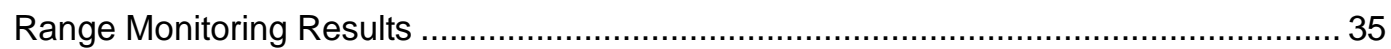

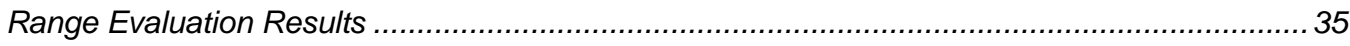

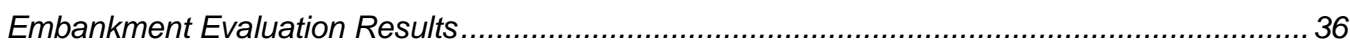

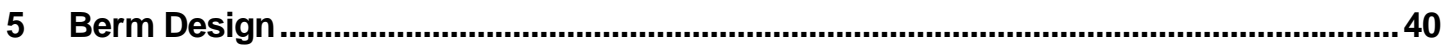

Embankment Soil Loss, Slope, and Vegetative Coverage .................................... 40

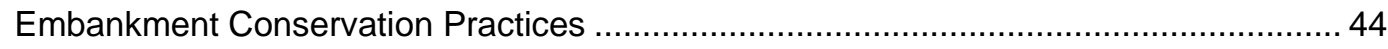

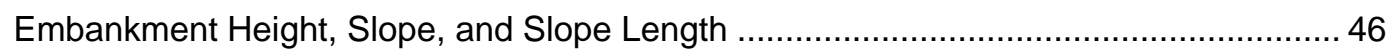

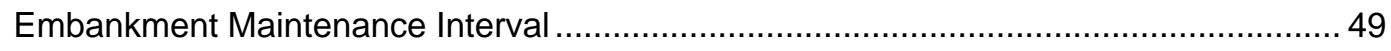

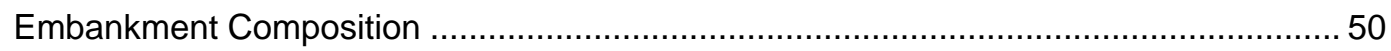

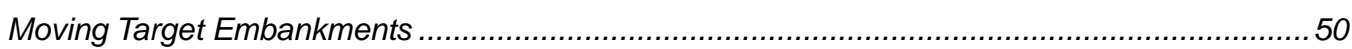

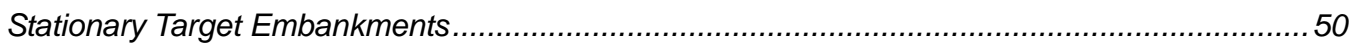

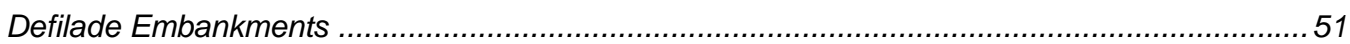

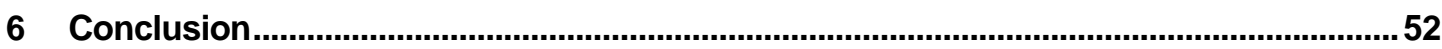

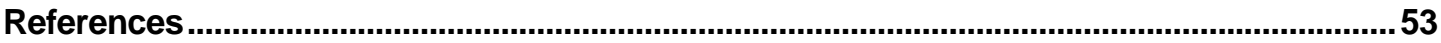

Appendix A: Standard Range Designs for RETS Ranges...................................................56

Appendix B: Soil Data and Information at Camp Atterbury, Indiana ...................................65

Report Documentation Page ..................................................................................................6 68 


\section{List of Figures and Tables}

\section{Figures}

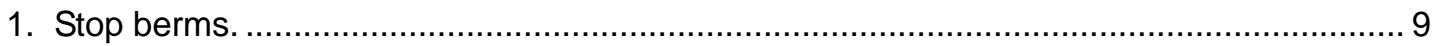

2. Newly revegetated embankment with severe toe erosion. ......................................... 10

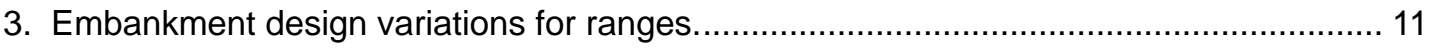

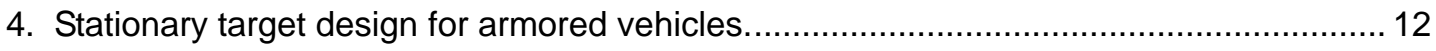

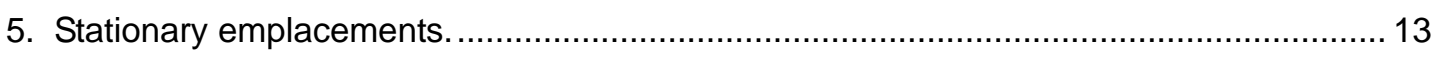

6. Stationary infantry target emplacement pattern erosion. ............................................. 14

7. Retaining wall damage on a stationary target emplacement. ........................................... 14

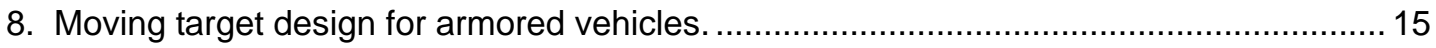

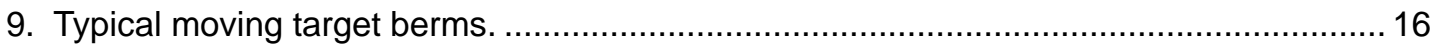

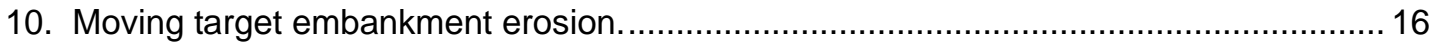

11. Rock check structures in use at Camp Atterbury, IN ................................................. 17

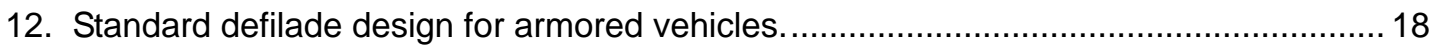

13. Defilades at MPTR, Range 37, Camp Atterbury, IN............................................... 19

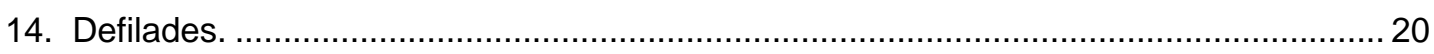

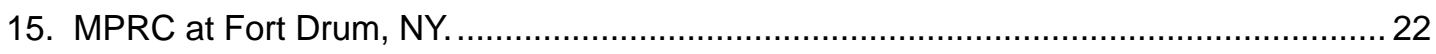

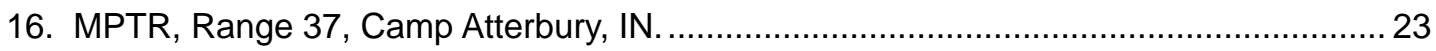

17. Camp Atterbury Joint Maneuver Training Center, IN. …........................................... 27

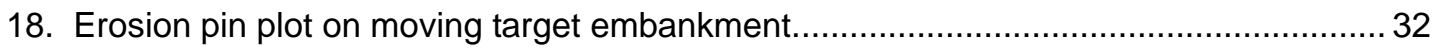

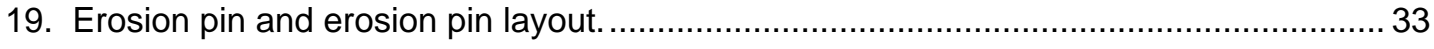

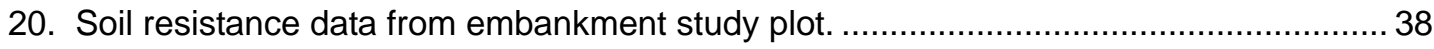

\section{Tables}

1. Estimated soil loss from military target embankments at 43 percent vegetation

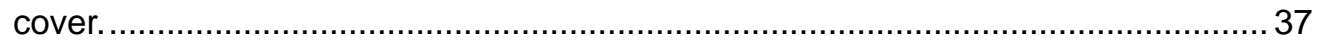

2. Atterberg limits for moving target embankment soils. ................................................. 37

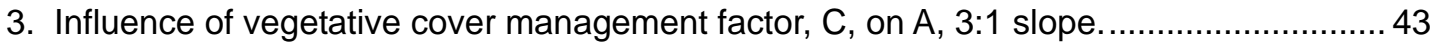

4. Influence of vegetative cover management factor, C, on A, 4:1 slope ........................... 44

5. Influence of conservation practice, $P$, (terrace and grass waterway) on $A, 3: 1$ slope....... 45

6. Influence of conservation practice, $\mathrm{P}$ (2 terraces, 1 waterway) on A, 3:1 slope. .............. 46 


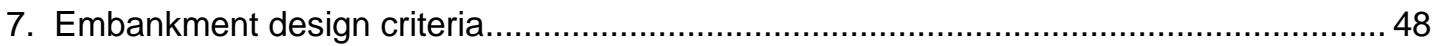




\section{Preface}

This study was conducted for the Office of the Director of Environmental Programs, under project A896, "Base Facilities Environmental Quality"; Work Unit number F50G68, "Range Design.” The technical monitor was Bill Woodson, DAIM-ED.

The work was performed by the Land and Heritage Conservation Branch (CN-C) of the Installations Division (CN), Construction Engineering Research Laboratory (CERL). The CERL Principal Investigator was Dr. Dick L. Gebhart. Part of this work was done by Dr. Prasanta Kalita, University of Illinois, Department of Agricultural and Biological Engineering under contract No. DACA88-99-D-0002. The technical editor was Gloria J. Wienke, Information Technology Laboratory. Dr. Dick Gebhart is Acting Chief, CEERD-CN-C, and Dr. John T. Bandy is Chief, CEERD-CN. The associated Technical Director was Dr. William D. Severinghaus, CEERD-CV-T. The Acting Director of CERL is Dr. Ilker Adiguzel.

CERL is an element of the U.S. Army Engineer Research and Development Center (ERDC), U.S. Army Corps of Engineers. The Commander and Executive Director of ERDC is COL James R. Rowan, and the Director of ERDC is Dr. James R. Houston. 


\section{Introduction}

\section{Background}

In the interest of national security, United States policy directs the Department of Defense (DoD) to defend the country and protect its interests abroad. To accomplish this goal, the DoD operates the largest and most diverse training enterprise in the world to support 3.2 million uniformed and civilian personnel operating at 6000 locations and using roughly 121 thousand square kilometers ([km²] 30 million acres) of land (Office of the Secretary of Defense [OSD] 2003). The Department of the Army, as a branch of the DoD, is committed to following this doctrine. The Army has under its authority 1.3 million uniformed and civilian personnel at over 4100 locations utilizing over 61 thousand $\mathrm{km}^{2}$ (15 million acres) of land (Office of the Deputy Under Secretary of Defense [ODUSD] 2003). To fulfill its mission requirements and respond to national security threats immediately, the Army must maintain a state of continual combat readiness. Providing realistic and effective training is one of the key elements to the success of this strategy and will present challenges in the coming years. The sustainable use of military training lands presents a challenge to maintaining combat preparedness.

Loss of training land utility to soil erosion at many installations clearly indicates that military training lands are limited resources requiring careful management. To manage training lands more effectively in an era of budgetary constraints and environmental compliance, the Army requires effective land management techniques (Vachta and Hutchinson 1990). In addition, effective erosion control management plans are needed to sustain quality rangelands in support of the Army training mission. A major difficulty facing land managers is how to apply limited financial resources to soil erosion problems that continually reoccur. There is an unmistakable need for cost-effective long-term solutions that alleviate maintenance requirements and increase training intervals. To meet this need, DoD organizations such as the U.S. Army Environmental Center (USAEC) and the Army Training Support Center (ATSC) have introduced guidelines for land managers on the design of small arms ranges to prevent erosion (USAEC 1998). Additionally, the 
U.S. Army Engineering and Support Center (CEHNC), Huntsville, Alabama, published a design manual for remote target system (RETS) ranges to assist in the development of new ranges (CEHNC 2004*). The design manual details construction guidelines of new training ranges and new training range structures. However, these guidelines do not incorporate sustainable range elements into the overall design, and without proper soil and water conservation, large ranges have the potential to contribute greatly to overall installation erosion.

\section{Objective}

The objective of this research was to evaluate design weaknesses and develop an improved design methodology for firing points, defilade positions, and stationary munitions impact positions on training ranges.

\section{Approach}

A research team consisting of members from the University of Illinois, UrbanaChampaign (UIUC) and the Engineer Research and Development Center's Construction Engineering Research Laboratory (ERDC-CERL) determined that problem visualization and input from various Integrated Training Area Management (ITAM) personnel was essential to develop a design and maintenance solution for larger ranges. To this end, the research team visited four installations between March 2003 and July 2004. The installations were visited in the following order: Camp Atterbury, IN; Fort Knox, KY; Fort Drum, NY; and Fort Benning, GA. ITAM personnel guided the visits at each installation and highlighted problem areas on various ranges.

\section{Mode of Technology Transfer}

Information in this report will be used in design demonstration projects and will be incorporated in future revisions of the RETS Range Design Manual, CEHNC 1110-1-23.

This report will be made accessible through the World Wide Web (WWW) at URL: http://www.cecer.army.mil

\footnotetext{
* The RETS Range Design Manual , CEHNC 1110-1-23, 1 Dec 2004, is an online document available through http://www.hnd.usace.army.mil/rtlp.
} 


\section{Installation Range Evaluation Visits}

\section{Camp Atterbury, Indiana}

The Camp Atterbury Joint Maneuver Training Center is an Indiana National Guard and United States Army Reserve training facility that accommodates multiorganizational training for military forces, state police, and local police. Camp Atterbury, established in 1942, is located in south-central Indiana approximately 64.4 $\mathrm{km}$ (40 miles) south of Indianapolis. This installation is situated on approximately $135.6 \mathrm{~km}^{2}$ (33,500 acres). The soils of the installation are classified as discontinuous loess on bedrock and are finely textured silty clays and silty loams (Noble et al. 1990).

The first visit to Camp Atterbury occurred on 10 March 2003. This initial assessment outlined the framework for assessing the quality of ranges at other installations. The northern small weapons training facilities (non-mechanized) were inspected first and included Ranges 3, 4, 9, 10, 13, 14, and 18. Firing areas, separation embankments, infantry target emplacements, and backstop berms were all examined for degradation. Overall, the northern small arms ranges were observed to be in fair to excellent condition with the majority of damage occurring in areas near the target emplacements. Some of the older backstop berms had deteriorated embankment faces due to years of impact from ammunition. However, good vegetation stands prevented large amounts of sediment movement from the embankment face.

After completing assessments of the northern training ranges, the research team moved to the southern portion the installation. This region of the installation encompasses the recently completed multi-purpose training range (MPTR), Range 37. At this range, defilades, stationary targets, moving targets, and roads were inspected and the vegetative conditions of the structures and the surrounding area were recorded. The topography of Range 37 is greatly varied and the soil was noticeably susceptible to erosion. Quality of the vegetation on the range varied from poor to good while the vegetation on large range structures was poor to fair. Significant erosion was noted on embankment faces in areas where vegetation was lacking. At the time of inspection, no training had been completed on the range and this situation provided an excellent opportunity to examine natural range deterioration 
after construction. Additionally, the range illustrated the need for developing an aggressive revegetation effort following construction.

\section{Fort Knox, Kentucky}

Fort Knox is a U.S. Army Training and Doctrine Command installation with the primary mission of training soldiers for the Armor Force. Fort Knox is a certified Kentucky city, covering $441.3 \mathrm{~km}^{2}$ (109,054 acres). It is adjacent to the city of Radcliff, about $24 \mathrm{~km}$ (15 miles) north of Elizabethtown, and approximately $72.5 \mathrm{~km}$ (45 miles) south of Louisville. Fort Knox soils are finely textured silty clays, silty loams, and clay loams. Additionally, much of the installation is located in an area of high topographical relief with easily erodible soils (Arns 1979; Whittaker and Waters 1986).

The research team visited Fort Knox on 16 July 2003. This visit was scheduled to coincide with the construction of a new multipurpose range and a combined arms live-fire exercise at the installation to facilitate a better understanding of military training range construction practices and to observe armor weaponry effects on ranges. The examination of a new digital multi-purpose range complex (DMPRC) on the former Wilcox tank range grounds was undertaken first. Range construction activities and techniques were noted for the range complex. The team observed range structure subsurface layering, wetting, and compaction. The team also observed the development of defilade, stationary target, and moving target embankments and drew comparisons to established range design guidelines. Subsurface embankment compaction techniques appeared to be sufficient and according to

guidelines of the RETS Range Design Manual. The entire range was traversed to examine the range layout and surface preparation techniques (i.e., vegetation removal, wetland relocation, land grading, course road construction, and area drainage). Furthermore, the team interviewed site construction and environmental managers to assist in assessment of range construction methods at this site.

The second day was spent inspecting military vehicles and observing the combined arms live fire exercise (CALFEX) at the St. Vith Range. This demonstration illustrated typical air, mechanized, and infantry movement during simulated combat and was immensely beneficial in understanding the equipment directly causing the range degradation sustained during live-fire armor training. 


\section{Fort Drum, New York}

Fort Drum is located in Jefferson County, New York. It is approximately $48.3 \mathrm{~km}$ (30 miles) from Canada, with Lake Ontario to the west and the Adirondack Mountains to the east. Watertown is the nearest city, $48.3 \mathrm{~km}$ (30 miles) to the west, with Syracuse $145 \mathrm{~km}$ (90 miles) to the south. Fort Drum encompasses $434.1 \mathrm{~km}^{2}$ (107,265 acres). The area topography varies greatly from swampy low-lying areas to rock-complex outcroppings of higher elevation. The local soil is mainly sandy, rocky, and/or gravelly and soil classifications range from fine and course sands to sandy loams and sandy clays (USDA-NRCS, 2004a).

The team visited Fort Drum on 21 July 2004. The researchers met with range officials and toured six ranges representative of installation conditions. The facilities visited included one qualification range, one military operations on urbanized terrain (MOUT) range, one live-fire village, one breach range, one shootout range, and one multi-purpose range complex (MPRC). All complexes were evaluated for range maintenance and range design shortcomings; observations were recorded for later qualitative assessment. At the qualification range, embankment erosion was noted and was typical for smaller ranges at the post. The MOUT range inspection noted conditions of the structures and the surrounding footprint. The breach range was under construction at the time of the visit and a design variation using alternative separation barrier materials (shock-absorbing concrete [SACON]) was inspected. Range 23, the MPRC, was visited and range conditions were investigated. Defilades, stationary targets, and moving target embankments were inspected but attention was given to target design improvements and alternative design materials to enhance maintenance and trainability. Erosion on the moving target embankment faces was moderate to severe while erosion on the stationary target embankments was low to moderate. New defilade design options were investigated and compared favorably to existing recommended practices. Cabled concrete used for muzzle blast protection on defilade structures was noted as a future potential design alternative. The research team discussed overall range design processes and range layout options with range officials. Topics ranged from improving range terrain profile utilizing target structure camouflage to proper range structure siting to minimize range construction costs and future maintenance.

\section{Fort Benning, Georgia}

Fort Benning is located in the lower Piedmont Region of central Georgia and Alabama, about $9.7 \mathrm{~km}$ (6 miles) southeast of Columbus. The post consists of approximately $744.6 \mathrm{~km}^{2}$ (184,000 acres) of river valley terraces and rolling terrain. The moderate climate and terrain are well suited for infantry training and support mis- 
sions. The soils at Fort Benning consist of sands and loamy sands in upland areas while sandy loams and sandy clay loams are predominant in valleys and riparian areas (USDA-NRCS, 2004b).

The research team visited Fort Benning on 26 July 2004. During the visit, they investigated seven different ranges: a live-fire mechanized course, an urban assault course, a breach training facility, an M-60 night infiltration course, one DMPRC, an M-16 modified rapid-fire range, and a small arms training range. Typical erosion problems and maintenance issues on the installation were found on these ranges. Vegetation establishment was poor on many embankments at the various ranges visited. At the DMPRC, thin layers of topsoil were observed on the new embankments to promote grass growth, but heavy rains had washed away a significant portion of the topsoil near the crest of the berms at all ranges. Similarly, the separation embankments at the breach training facility were inspected and a minimal amount of topsoil was observed. At several of the ranges significant embankment base erosion was prevalent, potentially creating structural instability and downstream drainage problems. Embankment grass growth was moderate to poor with ryegrass exhibiting better growth than bahia grass.

Several embankments on the live-fire armor and Bradley Fighting Vehicle (BFV) range were inspected. Here, two erosion control methods were found: a retention pond and several erosion check dams. Observation determined that the area had excellent vegetation coverage. The research team gathered range conditions on defensive positions, target positions, stationary armor positions, and temporary ambush targets. Sparse vegetation coupled with erosion on these structures was predominant. On a visit to the night infiltration course, the research team found a newly constructed berm in use for several months. The slope of this berm was less than $1: 1$ on both sides due to space limitations. Because no vegetation was established, the berm had experienced significant soil erosion and was already in need of maintenance. Finally, the team visited two small arms ranges. These ranges had numerous small berms and several large berms. Vegetation coverage was fair and erosion rate was observed to be high on the embankments.

Overall, the ranges visited at Fort Benning exhibited signs of high soil erosion (rills, gullying, deposition, etc.). Many berms had inadequate side slopes, insufficient topsoil, and moderate to poor vegetation cover - all factors conducive to high levels of soil movement. 


\section{Summary of Findings: Installation Evaluation Visits}

The range issues found on the four installations appear to be typical of most temperate climate installations. Those issues are as follows:

- High levels of erosion were found at all installations and were mainly concentrated in localized areas of training activity. The severity of the erosion problem appeared to depend on soil type, topography, range usage, and frequency of maintenance. Poor vegetation was noted in all areas with severe erosion problems.

- Range maintenance and range development costs were dependent on the proper site location of a range. Improper siting of range structures lead to an increase in range construction costs and more frequent maintenance. Installation range personnel concurred with this observation.

- The design of range layouts was investigated at each of the four installations. Potential areas for improvement of these designs were recorded. Areas of concern were target profiles, embankment heights, and embankment camouflage. Military personnel rely on training ranges to provide an element of realism to a training scenario. Improvement of range structure profiles and the introduction of camouflaging techniques/vegetation were noted as possible solutions that could provide an element of surprise to improve training effectiveness.

- Alternatives to standard range structures such as defilades, stationary target structures, and moving target emplacements were frequently observed at all installations. The use of geo-textiles, articulating cellular concrete block systems, soil stabilizers, and different methods of range construction were encountered. Many of these alternative materials merit future investigation as to their effectiveness in range designs.

- Soil conservation structures were observed at many of the ranges at each of the four installations. Sediment detention basins, grass waterways, rock check dams, low water stream crossings, microterracing, and soil stabilization techniques were observed. However, the use of such structures was not consistent throughout an installation. Often such structures were placed as a reactionary measure instead of a preventative measure. To mitigate potential soil loss, problem areas need to be identified early. Regardless, soil and water conservation techniques should be applied uniformly throughout an installation to reduce soils losses and decrease maintenance costs over the long term.

These four installations illustrate range conditions typical in temperate climates and do not wholly account for problems encountered at installations in arid regions. 


\section{Range Design Analysis}

After the research team returned from the four field investigations, a plan was developed to combine the field observations of past designs with a critique of current range designs and future range design proposals. Range evaluations highlight the strengths and the shortcomings of range designs and are the center of discussion in the following sections.

Earthen embankments are integral to stationary target structures, moving target structures, defilade emplacements, ordnance-stop embankments, and separation barriers. During military training, embankments are subject to impact ordnance from mechanized, aerial, and infantry weaponry. According to the Army Corps of Engineers' RETS Range Design Manual, embankment structural design requirements specify that earthen emplacements withstand the impact of ordnance without structural failure (CEHNC 2004). Installation visits confirmed that all range berms were able to withstand weapons impact without substantial structural degradation to the embankment. The range evaluations determined that the primary design and maintenance issues were the impact of military maneuvers on the surface/subsurface soil matrix. Implementation of erosion control practices and timely maintenance are ideally suited to remediate this problem and reduce range structure damage.

The RETS Range Design Manual is the online guideline to assist in the development of ranges. The manual provides generic design guidance and required interface points for the following range designs:

- Antiarmor Tracking and Live Fire Range

- Automated Field Fire Range

- Automated Record Fire Range

- Battle Area Course

- Combat Pistol/Military Police Qualification Course

- Combined Arms Collective Training Facility

- Digital Multi-Purpose Range Complex

- Digital Multi-Purpose Training Range

- Fire and Movement Range

- Infantry Platoon Battle Course

- Infantry Squad Battle Course

- Live Fire Exercise Breach Facility

- Modified Record Fire Range 
- Multi-Purpose Scout Qualification Range

- Multipurpose Machine Gun Range

- Qualification Training Range

- Rifle/Machine Gun Zero Range

- Sniper Field Fire Range

- Urban Assualt Course

Of these designs, the digital multi-purpose training range, and the digital multipurpose range complex (see Appendix A, Figures A-1 through A-8 for design drawings) are the primary focus of discussion as those designs include structural elements found in smaller ranges. However, embankments on any range would be subject to similar criteria.

\section{General Embankment Design Analysis}

The main function of a berm is to protect personnel and equipment. While targeting and firing emplacements have established specifications to guide the designer in creating these range structures, designs do not currently exist for separation barriers and firing stops. Adapting target emplacement specifications for separation barriers and firing stops to accommodate this gap in design is essential to achieve optimum quality assurance during construction for all structures. Figure 1 shows separation barriers and ordnance stop embankments.

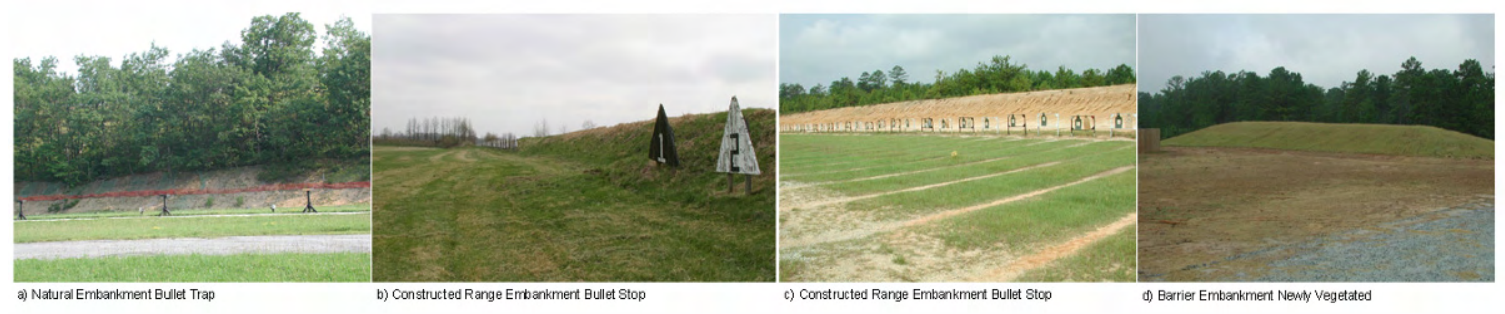

Figure 1. Stop berms.

(a) natural (b) aged (c) heavily eroded (d) revegetated.

With the exception of the far right embankment (d), the berms in Figure 1 contain areas of extensive localized erosion. On these embankments, localized erosion is the result of repeated military ordnance impact; the severity of erosion intensifies with higher training frequency. The embankments in Figure 1(a) and 1(c) exemplify poorly maintained and heavily used embankments in service less than a decade. The embankment of Figure 1(b) represents a highly used, well-maintained embankment in service over several decades. Clearly, embankment maintenance practices have a great potential to reduce environmental risk. Embankment disturbance and subsequent soil movement have increased environmental risk for 
embankments in Figure 1(a) and 1(c). Mitigating topsoil disturbance from weapons impact is a significant maintenance challenge as vegetation reestablishment is difficult on the remaining eroded nutrient-poor soil.

Investigations of newly constructed embankments as in Figure 2 revealed another problem at several training areas. Frequently, range soil conservation efforts concentrate on the range structure, but fail to encompass the surrounding areas. Embankment construction changes the local hydrological characteristics creating potential stresses on the surrounding watershed. The embankment in Figure 2 exhibited rill formation at the embankment toe and substantial erosion of the adjacent area. Embankment toe undercutting reduces berm stability and may cause embankment failure. Furthermore, the soil lost from this area increases environmental risk in locations down gradient of the embankment.

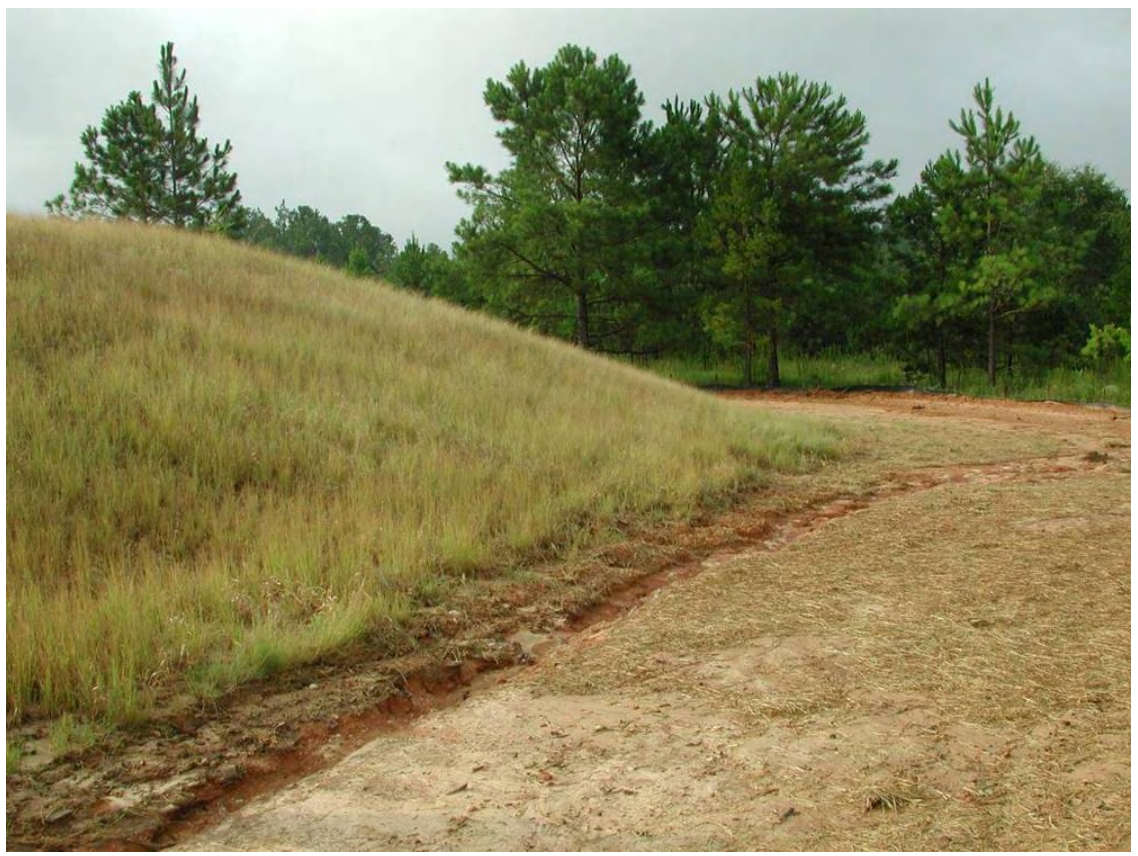

Figure 2. Newly revegetated embankment with severe toe erosion.

\section{Target and Firing Emplacement Design Analysis}

The orientation of multiple firing points in angle, height, and distance to multiple targets situated throughout a range is a critical design component. The positioning of firing and target emplacements are outlined in the RETS Range Design Manual. Four embankment design types specified in the design manual protect target and firing structures from damage as seen in Figure 3. 


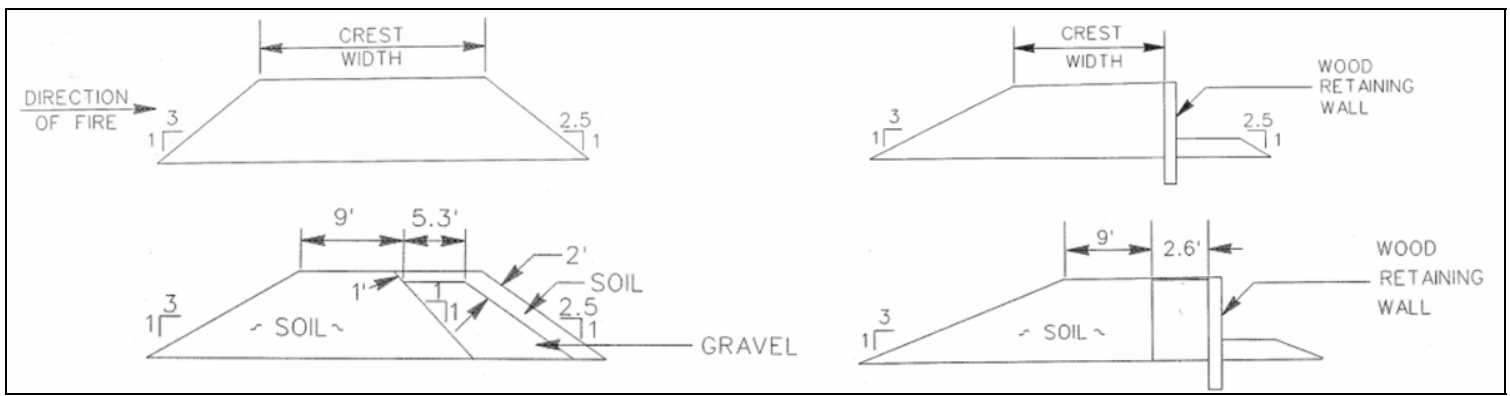

Figure 3. Embankment design variations for ranges.

The RETS Range Design Manual allows selection of embankment type for firing and target emplacements using location, topography, soil properties, and training requirements. Additionally, the guidelines identify acceptable materials for the construction of these embankments (mainly wood and concrete). However, the installation visits confirmed that construction methods and materials varied. Liberal interpretation of the design guidelines has led to structure inconsistency and uncertainty in estimation of berm stability and longevity, presenting a challenge to maintenance scheduling on a widespread basis. Observations of range construction activities at Fort Knox validate the need for routine checking of embankment design specifications during the build phase. Furthermore, older embankment conditions at the four military installations exemplified the need for adherence to established maintenance guidelines. An in-depth analysis of the target and firing emplacements follows.

\section{Stationary Target Emplacement Analysis}

Stationary emplacements are present on small ranges as infantry target emplacements, and on larger ranges as both armor target emplacements and infantry target emplacements. Review of the RETS Range Design Manual regarding stationary target emplacements indicated several design issues requiring further scrutiny. Embankment slope, embankment face composition/erosion control, and emplacement profile guidelines were found to be inadequate or nonexistent. This finding was based on 30 stationary target inspections and numerous design critiques. Figure 4 shows typical stationary target emplacements. Appendix A contains the complete design. 


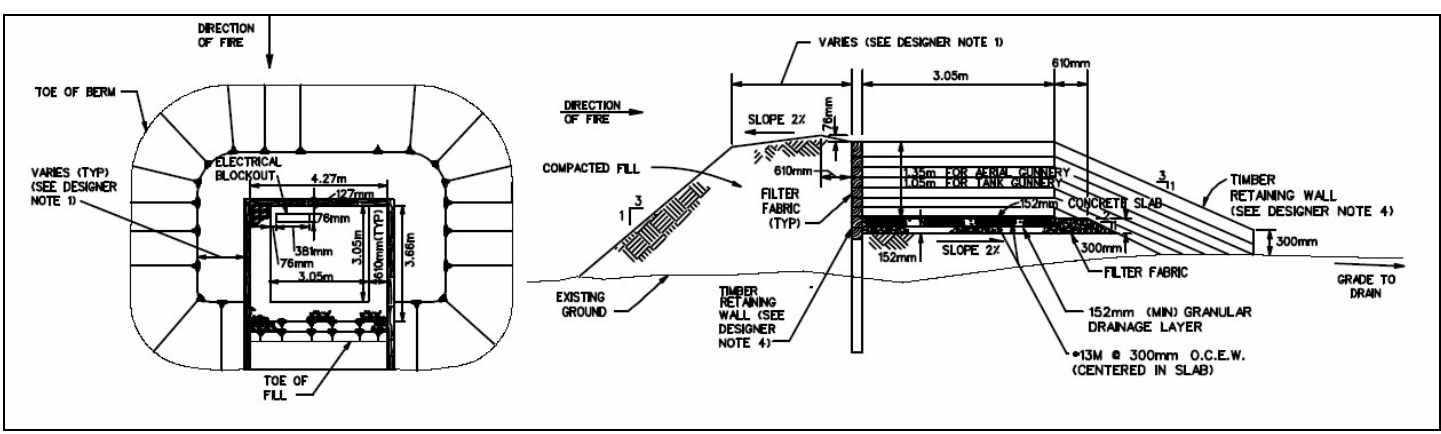

Figure 4. Stationary target design for armored vehicles.

The design manual recommends an embankment slope of 3:1 and requires a geotechnical investigation to justify the use of lesser slopes. During embankment inspections at Fort Benning and Fort Drum, the research team observed slopes steeper than the design specification of 3:1. Many of these embankment slopes had extreme erosion problems. Embankment inspections at Camp Atterbury indicated that surface soil conditions (see Appendix B for further details on Camp Atterbury soils) necessitated a design slope of $4: 1$ or the installation of erosion control structures. Nonetheless, a 3:1 slope was constructed, which continually presents a maintenance challenge. When done correctly, determining embankment slope design criteria requires an assessment of soil parameters, maintenance requirements, and area hydrology. Employing a conservative range design strategy with adequate slopes will ease future maintenance requirements and cost less over the long term.

The design guidelines clearly outline berm thickness requirements. Embankment thickness calculations use a combination of soil and weaponry parameters such as the Unified Soil Classification system, the plasticity index, the maximum dry density for compaction, ordnance size, and allowable firing location. Embankment investigations at the four installations revealed that berm thickness was sufficient per the design recommendations. Based on adherence to these dimensional parameters, embankment core design requirements were adequate. However, no design guidelines exist to determine the composition of the embankment face. This top layer of soil is critical to maintaining berm integrity and retaining berm functionality over the design life of the berm. Knowledge of soil structure, vegetation requirements, and erosion control practices is necessary when developing guidelines for this new criterion and extending berm life.

Erosion on stationary target embankments is the result of inadequate design, infrequent range maintenance, and high training use. The sparsely vegetated embankment of Figure 5(c) typifies emplacements under such conditions. Initially, vegetation cover in Figure 5(c) was similar to that of Figure 5(a). In this instance, berm soil loss from the embankment top produced subsequent problems near the bottom of the embankment. A lack of near-surface embankment stabilization techniques 
contributed greatly to the deteriorated conditions of the far right image in Figure $5(\mathrm{c})$.

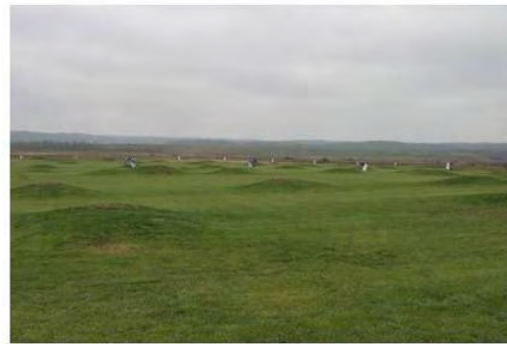

(a) Camp Atterbury, IN Figure 5. Stationary emplacements.

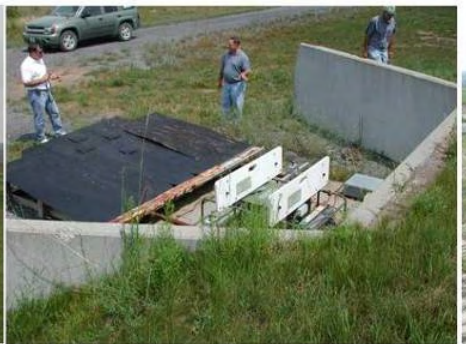

(b) Fort Drum, NY

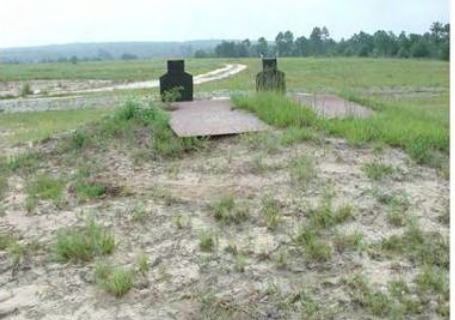

(c) Fort Benning, GA

The embankment area of a stationary target emplacement is many times smaller than the embankment area of a moving target emplacement. In light of this fact, the need for erosion control practices is more evident on moving target emplacements and discussion on erosion control needs will occur in the moving target embankment section. However, it is worth noting that the cumulative soil loss from numerous stationary targets can be substantial and the use of erosion control techniques for smaller berms is important, especially from the perspective of environmental compliance.

Figure 6 depicts heavily used embankments exhibiting pattern erosion on the embankment face. The ability of a berm to recover from pattern erosion largely depends on the soil type, the established vegetation, the amount of range training activity, and the embankment maintenance interval. Weapon fire initiates pattern erosion on stationary targets, removes vegetation from the topsoil, and changes aggregate topsoil mixture through impact. Embankment observations demonstrated that well-established ground cover and gradual slope angles limited the effects of pattern erosion. For example, stationary embankments with slopes of 5:1 and 6:1 had noticeably less pattern erosion and soil loss on the embankment face than stationary embankments with slopes of 3:1. Two factors explain this phenomenon: the change of ordnance impact angle and the reduction of soil movement potential. These two factors limited slope damage and erosion, allowing a better opportunity for vegetation persistence and recovery. Incorporation of these factors into the design criteria will enable longer maintenance intervals and improve the embankment profile. Additionally, lesser slopes provide an improved training target by reducing the embankment profile. 

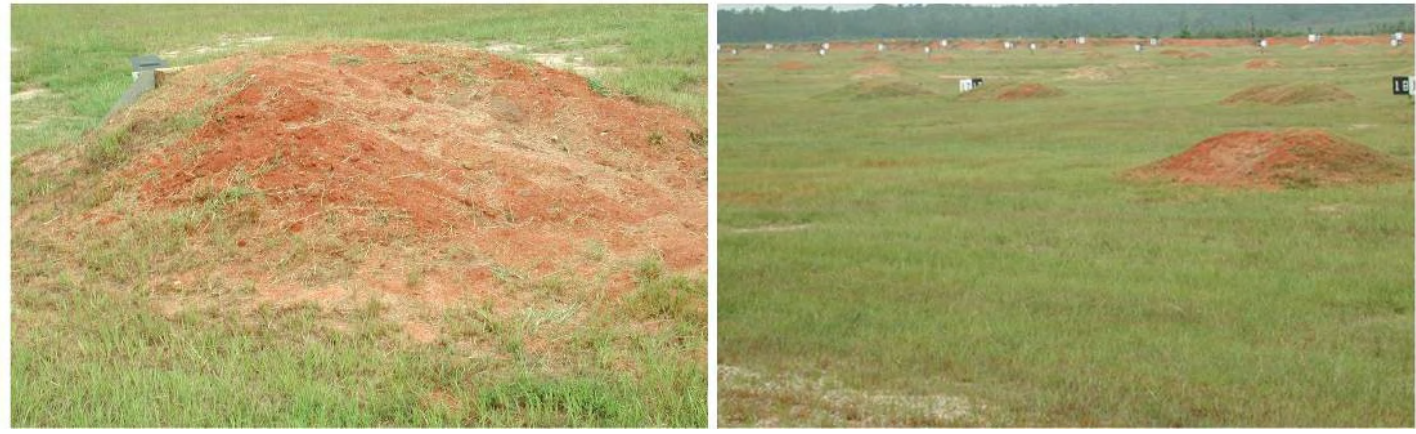

Figure 6. Stationary infantry target emplacement pattern erosion.

The earthen embankments protect the target superstructure from ordnance damage. Yet damage to the target superstructure does happen. For example, Figure 7 shows damaged retaining walls. This damage, though ostensibly superficial, has shortened the useful lifespan of the structure. The cyclic processes of freezing and thawing will eventually take their toll and hasten degradation over time. This problem is preventable and opportunities exist to circumvent this problem using a combination of materials. The RETS Range Design Manual specifies the use of wood rail ties with filter fabric. An allowable design substitution is concrete. The research team found that alternative materials such as geo-textiles were being used at several installations in the construction of stationary target superstructure walls. Review of the design guidelines brought to light deficiencies in the use of wood and concrete. Wood rail ties, although cheap and effective, have a shorter useful design life than concrete. Concrete is durable and long lasting, yet susceptible to impact damage. The shorter lifespan of wood rail ties is a potential problem during routine target rehabilitation. The removal of the ties disturbs the compacted subsoil possibly compromising berm integrity on smaller emplacements. Optimum combinations of wood, concrete, and geo-textiles require further investigation to prolong retaining wall life and reduce the potential for ordnance damage.
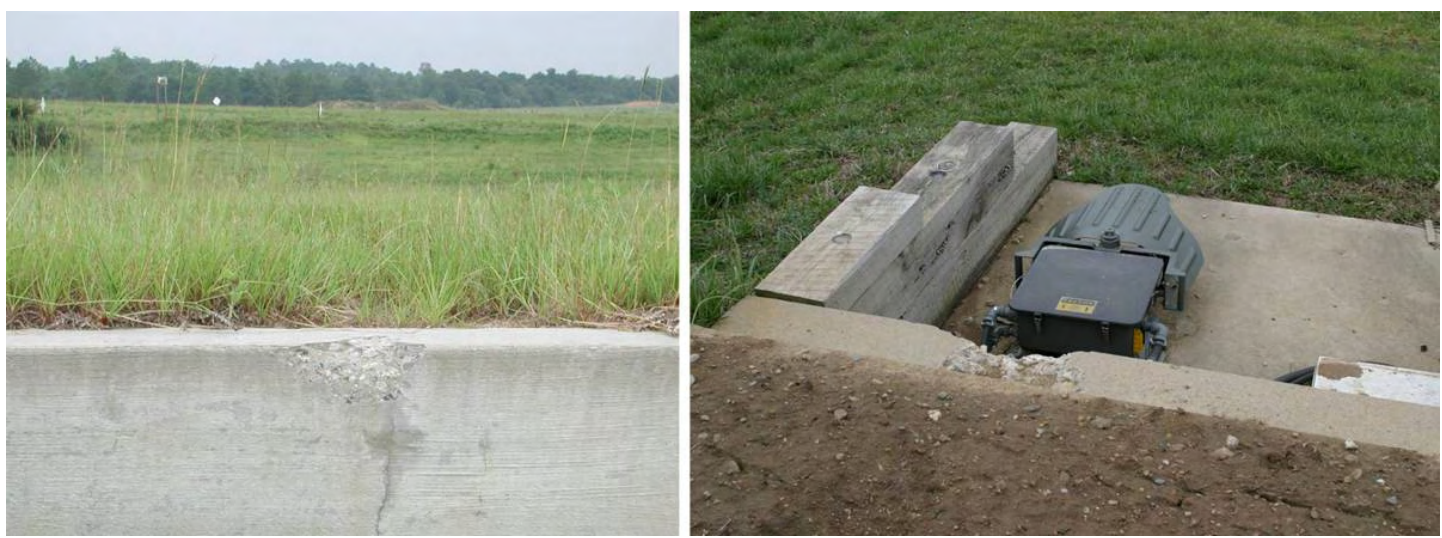

Figure 7. Retaining wall damage on a stationary target emplacement. 
Serviceability of the stationary armor target emplacements is an area of concern. Several range personnel expressed a desire to see stationary armor targets have increased accessibility to range maintenance personnel. The standard design as seen in Figure 4 indicates that the target mechanism be partially enclosed in a rectangular area behind the embankment. Several target mechanisms had structural modifications incorporating an angled target box design for easier serviceability [Figure 5(b)]. Upon further design review, an angled stationary armor target box is an alteration that will increase range serviceability.

\section{Moving Target Embankments Analysis}

Moving target embankments are used extensively on multipurpose training ranges, multipurpose range complexes, and tank gunnery ranges. They are used to protect armor target emplacements and are one of the largest structures constructed on a training facility. Figure 8 shows the design guidelines for this structure; Appendix A shows the complete design.

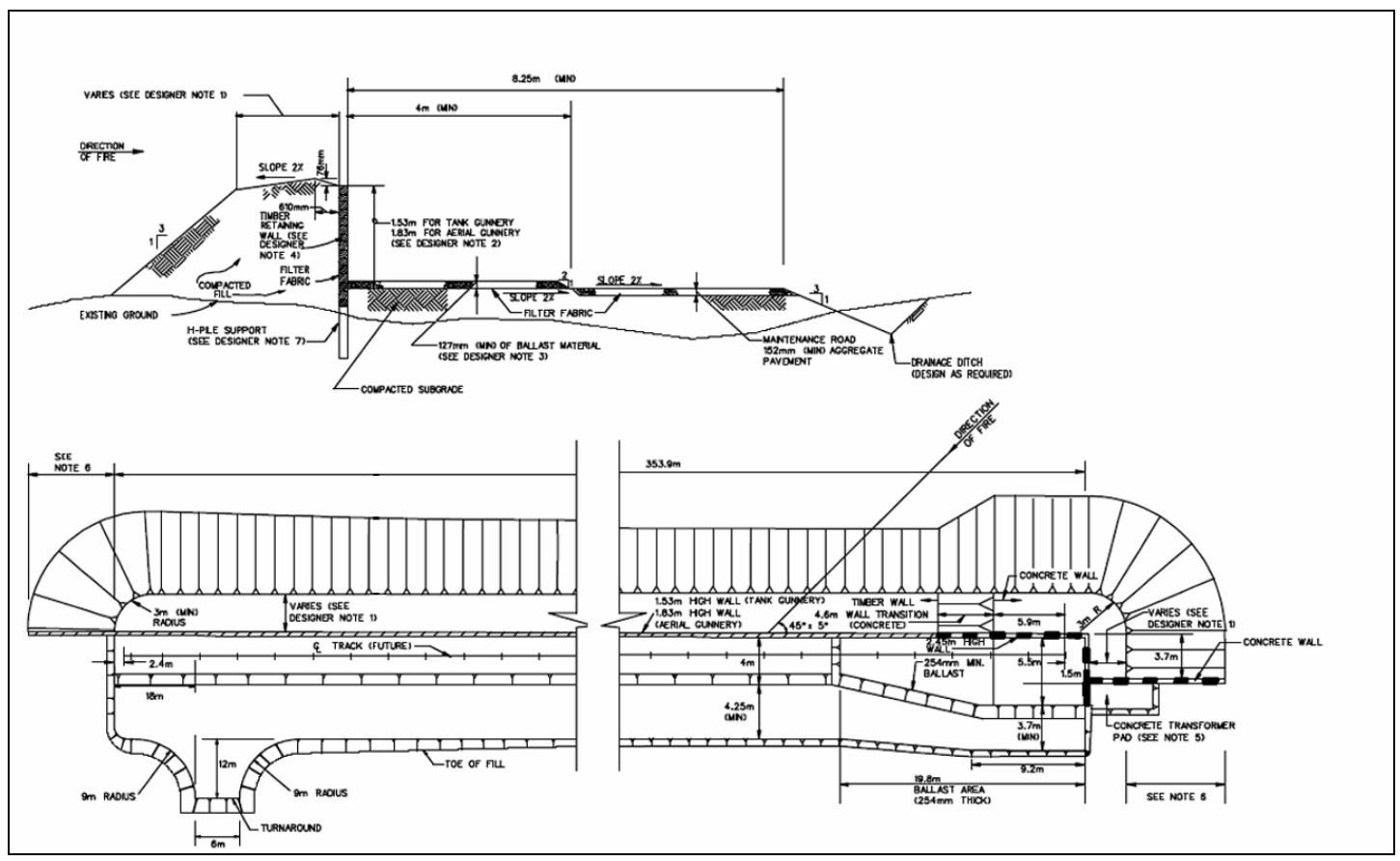

Figure 8. Moving target design for armored vehicles.

Scrutiny of the moving target design guidelines and the drawing specifications in the RETS Range Design Manual found several items warranting further analysis. The design weaknesses of moving target emplacements are similar to stationary target emplacements and have been discussed in the previous sections. As with stationary target emplacements, embankment slope dimensions, embankment face composition, berm erosion control methods, emplacement profile restrictions, and target emplacement superstructure were analyzed and deficiencies were noted. 
Typical moving target emplacements are shown in Figure 9. Note the erosion on moving target berms.

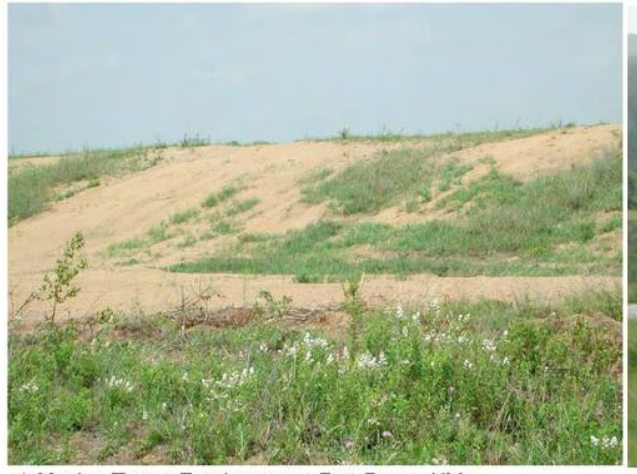

a) Moving Target Emplacement Fort Drum, NY

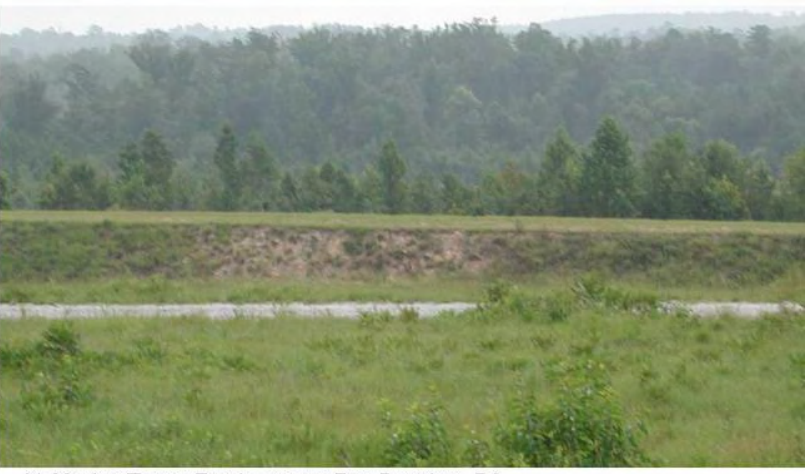

b) Moving Target Emplacement Fort Benning, GA

Figure 9. Typical moving target berms.

Slope dimensions were the first design criteria analyzed for moving target berms. Slope angle was discussed as a design issue during the analysis of stationary targets; moving target emplacements follow the same criteria. Slope angles of moving target embankments were examined at each installation visited. The slope angles appeared to follow the design criteria. Several were measured to validate compliance and were found to be in the range of 3:1 to 4:1. At Camp Atterbury, the largest embankment on a multi-purpose training range had a side slope of 3.2:1. The erosion of Figure 10 shows this slope to be insufficient for the soil type. Berm thickness, as with stationary target emplacements, seemed to be satisfactory at every installation.

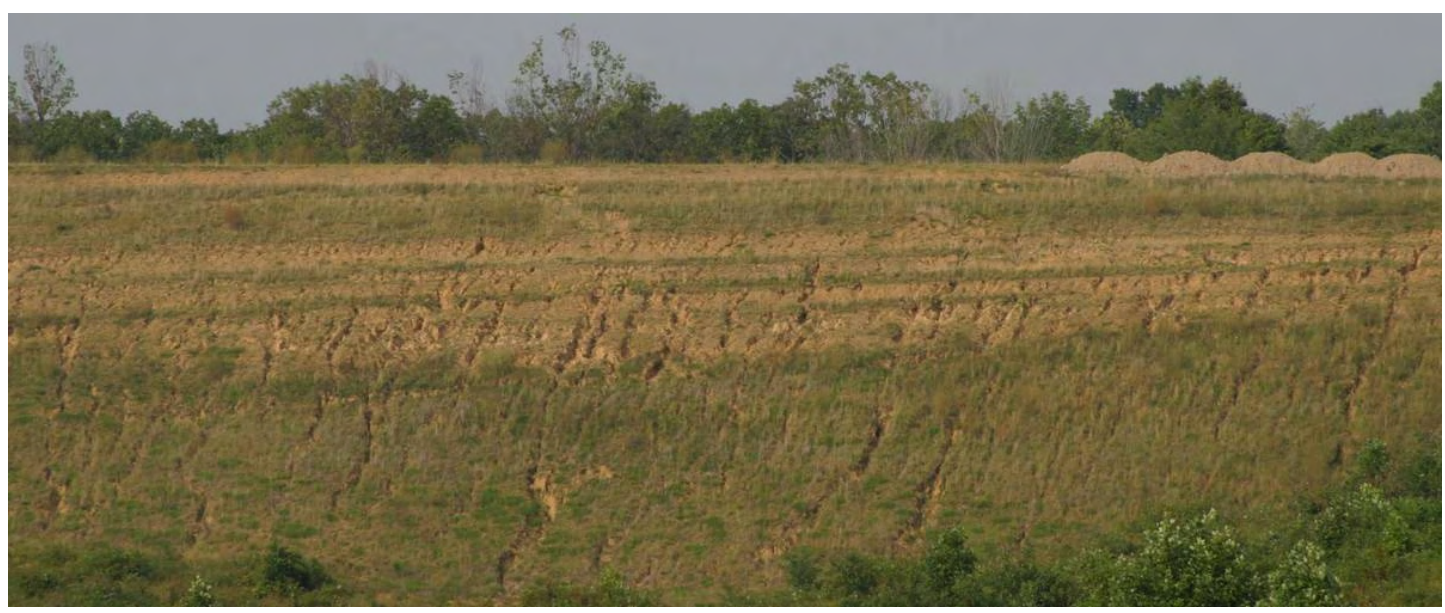

Figure 10. Moving target embankment erosion.

Referring again to Figure 10 as an example, slope length was determined to be a more critical issue on moving target emplacements than stationary target emplacements. When ranges are placed in areas of high relief and berms are built to ac- 
commodate line-of-sight constraints, slope length erosion problems increase as the height of the embankment increases. Slope length guidelines and erosion control techniques are essential to prevent the erosion shown in Figure 10. Related to slope length is embankment height; line-of-site analysis requires that embankments provide a direct visual line from the firing point to the target. On large ranges, this requirement often dictates that target emplacements at the end of the range be substantially higher than emplacements near the beginning of the range; limitations on berm height in conjunction with slope length are recommended. Furthermore, additional emphasis on erosion control and embankment stability is required on berms that are more elevated.

During installation visits it was noted that few erosion control measures were in place on any of the embankment faces or in the surrounding drainage outlets. Occasionally rock check dam structures were used in the drainage areas surrounding the berm (see Figure 11). The use of rock check dams was not a common practice except on the MPTR at Camp Atterbury where a lack of vegetation was causing severe rill and gully erosion in the waterways. One range at Fort Benning did have erosion control measures in place: rock-lined waterway channels and riprap embankments. None of the visited installation used surface roughening techniques, runoff containment structures, or embankment land formations that would suggest an effort to control runoff on or near the embankment face. The range design guidelines do not specify requirements for erosion control.

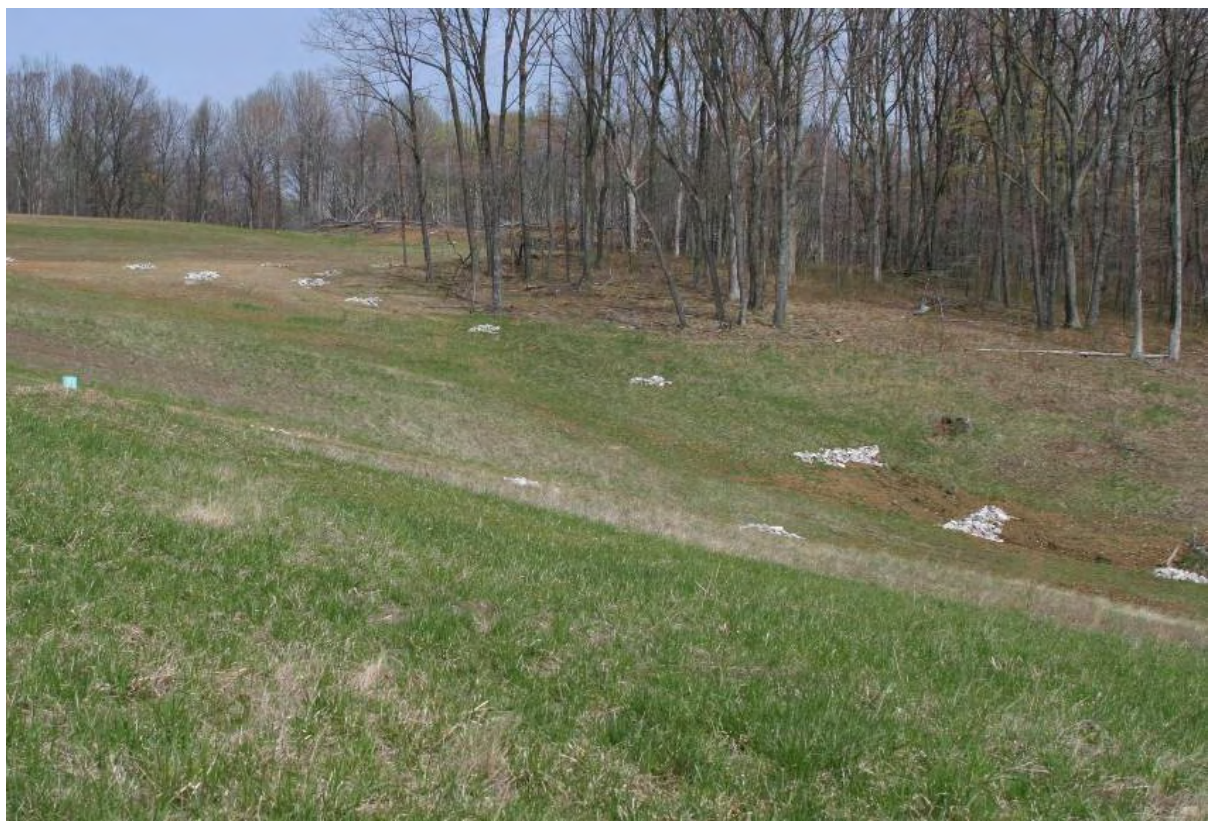

Figure 11. Rock check structures in use at Camp Atterbury, IN. 


\section{Defilade Design Analysis}

An armored vehicle can fire artillery from most locations on a range but firing emplacements (defilades) are designated engagement positions that allow tanks to maintain defensive hull down and turret down tactical positions. The primary construction materials used in defilade embankment design are earth, rock riprap and blast mats. (See Appendix A for complete design.) Defilades as shown in Figure 12 are not subject to intentional direct fire, yet damage does occur from armored vehicles. This damage occurs in two ways: armored vehicle collisions into the defilade structure and blast wave overpressure from the armored vehicle weaponry. The damage to the embankment from both forces has the potential to affect the embankment integrity depending on the local soil type and ambient soil moisture conditions.

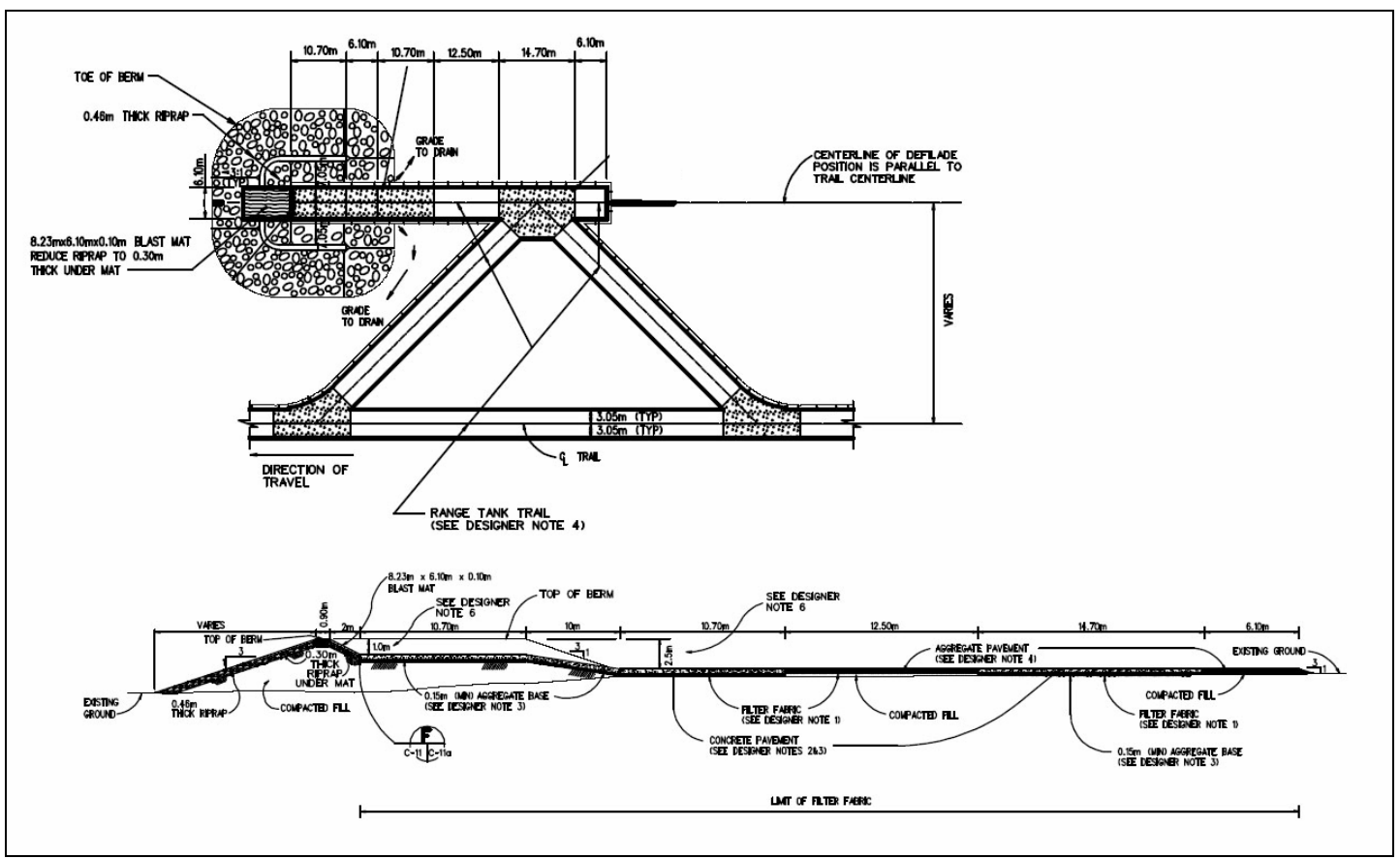

Figure 12. Standard defilade design for armored vehicles.

The impact force of an armored vehicle colliding into the defilade structure transfers a force from the structure into the soil. After impact, the resulting particle rearrangement has less strength than the previously undisturbed compacted soil. The force of impact from multiple vehicle collisions over time reduces the strength and integrity of the compacted embankment. This soil structure damage is most evident near the top of the retaining wall as loosened soil is more susceptible to transport by the blast force.

Blast wave damage to the embankment occurs after the blast force hits the structure surface. Mechanized weaponry discharge creates an instantaneous pressure 
front and a reflected incident pressure (mach front) at an angle between the rigid surface and the plane of the shock front. The resulting force can dislodge soil, fracture rock, and remove vegetation. Firing emplacement designs require the use of blast mats to dampen the blast wave overpressure and protect the embankment. Another concern, the blast fireball, scorches vegetation and ignites flammable blast mat materials. Obstructions placed on the embankment face to reduce soil erosion must consider the amplification of forces that would result from the reflection of the pressure wave on the embankment face. This phenomenon excludes the use of permanent erosion control structures such as terraces or sediment basins on the embankment face.

The defilade design utilizes rock riprap to stabilize the embankment and reduce erosion/dust generated by the blast wave. The image on the left-hand side of Figure 13 illustrates a blast mat to protecting riprap. The image on the right-hand side of Figure 13 illustrates the defilade superstructure. The merits of the three defilade designs and the material specifications contained within the RETS Range Design Manual follow.

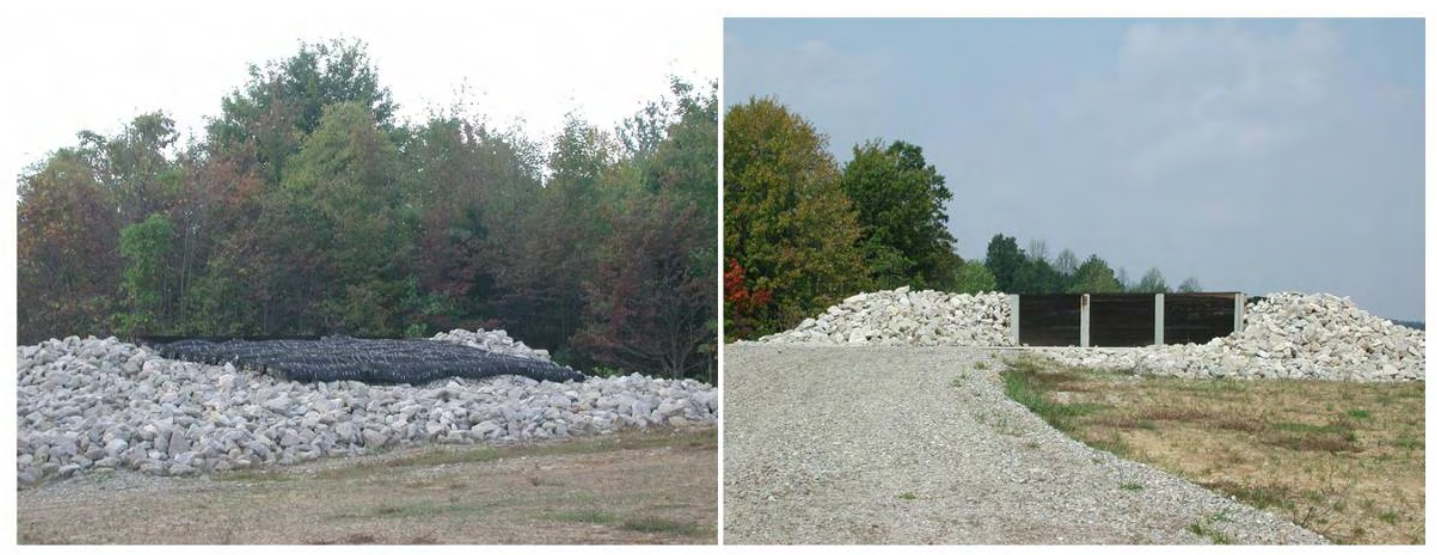

Figure 13. Defilades at MPTR, Range 37, Camp Atterbury, IN.

Many defilades were inspected during the installation visits. The defilades at Camp Atterbury were found to be in the best condition as this range was relatively unused at the time of inspection. The research team observed the construction of defilades at Fort Knox and recorded embankment construction methods. Construction practices were in accordance with the design guidelines. The defilades at Fort Drum and Fort Benning were most indicative of defilade conditions on high-use ranges. Figure 14 depicts two firing positions. The defilade on the left in Figure 14 uses an alternative blast mat of cabled concrete. The defilade on the right in Figure 14 uses no method of protection in the blast area and the resulting bare soil is shown. 


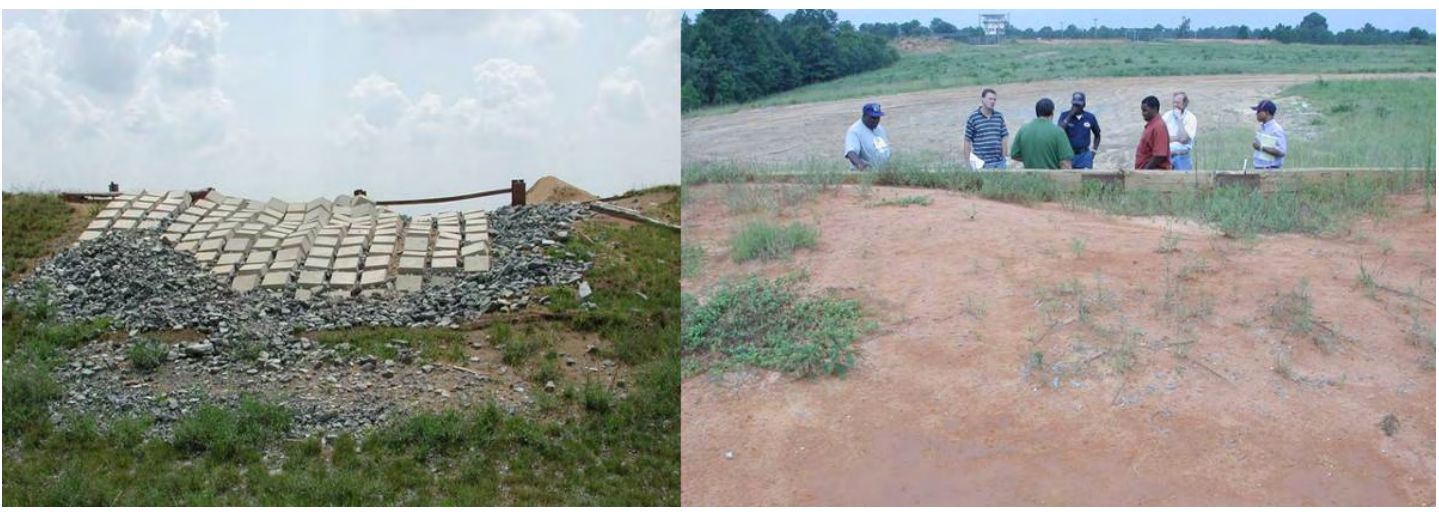

Fort Drum, NY

Figure 14. Defilades.
Fort Benning, GA

The defilade design guidelines require revision in several areas. Emplacement guidelines for slope, slope length and weapons blast, alternative materials specifications, and erosion control practices were investigated to increase emplacement longevity. Defilade embankment faces are subject to repeated blast forces. The damage of repeated weapons discharge on embankments caused visible vegetation loss and unknown soil structure degradation as is shown on the right in Figure 14. Visible damage to the blast mat and the soil structure on protected embankments such as the defilade in the left image of Figure 14 were also apparent. Embankment design criteria for defilades should include consideration of blast wave effects.

Alternative embankment defilade design materials were observed at Fort Drum. Several cable concrete blast mats were in use on multiple firing emplacements and had been in service for 5 years. Several of the defilade embankment structures were in need of maintenance (see left photo in Figure 14) but the bulk of embankment faces had intact surface soil structure and healthy stands of vegetation on the embankment. Cabled concrete blast mats were observed at a high-use MPRC and warrant further investigation as a low-cost substitute for tire blast mats.

\section{Comprehensive Range Design Analysis}

Given that training ranges are so large, it is essential that individual range elements minimize erosion and maintenance since the sum of environmental degradation from individual elements may reduce water quality and affect stream health. Improvements are necessary regarding range layout, range structure profile, and erosion control practices. 


\section{Range Structure Profile Analysis}

Range designs and layouts are based on the physiographical, environmental, logistical, and training doctrine requirements of the parent installation. Each installation strives to build realistic and effective training areas that simulate tactical scenarios or demonstrate equipment proficiency.. Proper placement of range structures, landscaped range profiles, and better erosion control practices can provide a superior training experience for military personnel over a longer period. In general, a comprehensive erosion control plan should be incorporated into construction/rehabilitation of a range as most ranges do not use extensive erosion control. Soil conservation structures such as check dams, sediment detention basins, rock riprap, grass-lined/rock-lined waterways, and low water-crossings were in use at several locations. However, most erosion control structures corrected existing problems; a planned comprehensive erosion control effort was not evident at any of the ranges visited.

The dimensional characteristics of a firing or target structure are set by military equipment line-of-sight requirements and ranges must accommodate the capabilities of mechanized equipment. Engaging targets in a realistic manner requires range lengths several thousand meters in distance and elevated targeting structures. As a result of these requirements, berm heights can be quite substantial using line-of-sight analysis. Using standard range designs in the RETS Range Design Manual, sample berm heights were calculated. On level ground, embankment heights at the edge of a range can exceed 12 meters. An analysis of new DMPRC designs at Fort Benning found that the maximum berm height for moving embankments was 10 meters and that the embankment slope length was 31 meters. Berm heights of 10 meters in easily erodible sandy soil on highly used ranges present maintenance challenges. Eroded berm tops are the likely future result based on observations of current ranges. Figure 15 illlustrates this phenomenon. Multiple exposed embankment target structures can be seen on this MPRC at Fort Drum. Denuded embankments diminish the value of the training experience by eliminating the element of surprise for military personnel that train on this facility multiple times. The use of sustainable range practices has the potential to reduce this problem. Topsoiling, mulching, and vegetation can enhance range structures and blend with the surrounding environment creating a more realistic training setting. 


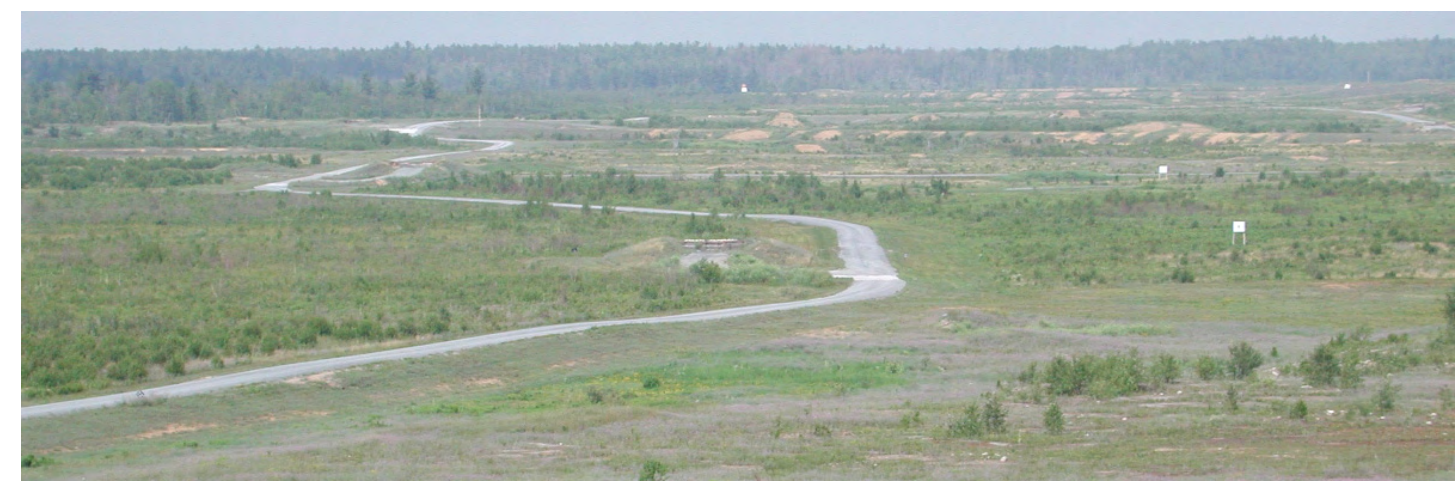

Figure 15. MPRC at Fort Drum, NY.

The analysis of general, stationary, moving, and firing embankments designs determined that overall subsurface embankment construction requirements are satisfactory. Adequate construction requirements are critical to achieving a long-lasting range structure. However, surface embankment requirements are not as clearly defined. Surface soil composition is an important element in maintaining vigorous and healthy stands of vegetation. Pre-range construction practices should include the stockpiling of the topsoil in an area where range-related structures would be erected. This effort preserves the natural soil for later redistribution on range elements and is advantageous to minimizing revegetation times.

\section{Soil and Water Conservation Implementation Analysis}

The research team observed and recorded the use of erosion control practices at the four installations. In general, a comprehensive erosion control plan was not used at installation ranges. Soil conservation structures such as check dams, sediment detention basins, rock riprap, grass-lined/rock-lined waterways, and low watercrossings were intermittently seen at ranges. These structures were discernibly placed to correct an existing problem such as severe erosion. These approaches, while beneficial and necessary, ideally should have been implemented before the damaging effects of erosion were apparent. An erosion control plan implemented during the construction phase of a range would minimize erosion maintenance expenditures. The MPTR region shown in Figure 16 is an outstanding example of the need for erosion control planning. During the construction phase of the range, large tracts of forested land were cleared for line-of-sight requirements. Unfortunately, a method to control erosion was not implemented. The steeply sloped landscape in Figure 16 has been severely eroded and would benefit immensely from the use of erosion control structures. Range officials at Camp Atterbury are now faced with long-term maintenance expenditures that would not be needed if an erosion control plan had been implemented initially. 


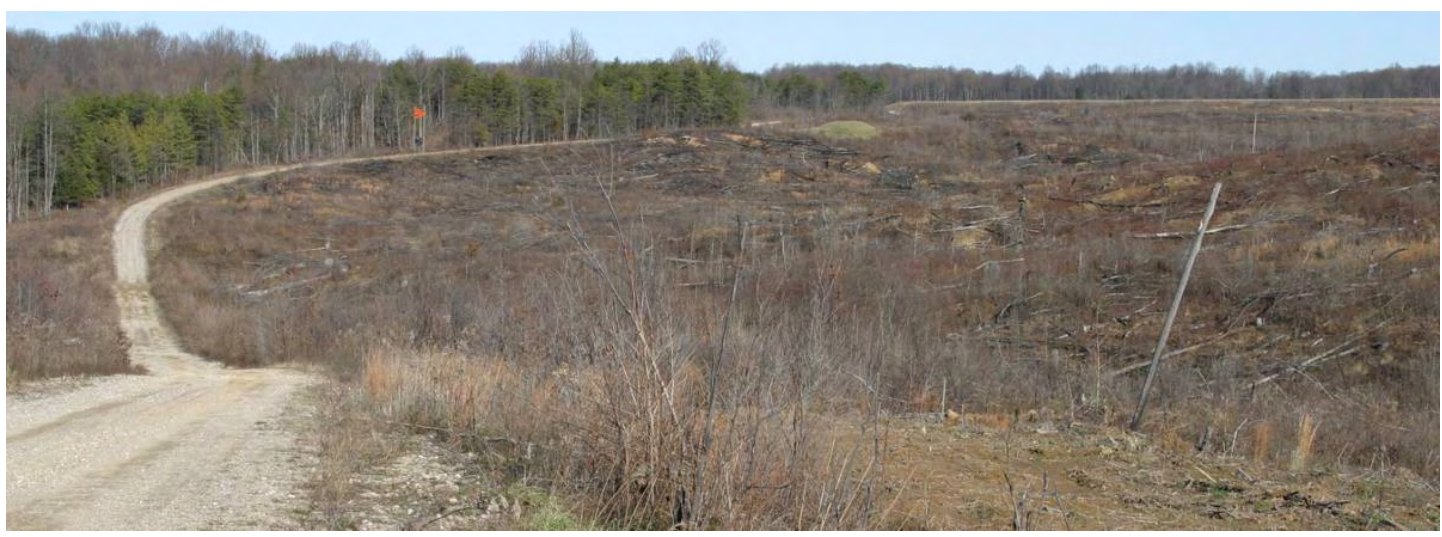

Figure 16. MPTR, Range 37, Camp Atterbury, IN.

\section{Range Analysis Summary}

This range design analysis has addressed the following elements: general embankment design, target and firing emplacement design, range structure profile design, and comprehensive soil and water conservation planning. Each of the range elements was examined and potential areas for improvement were noted. The following is a summary of those findings.

\section{General embankments}

- Develop embankment designs and guidelines for separation berms and ordnance stop berms.

- Alter embankment designs to accommodate erosion control structures.

- Substitute alternative embankment materials (SACON blocks, etc.) for earthen embankments when feasible.

\section{Moving Target Emplacements}

- Alter embankment designs to accommodate erosion control structures.

- Reformulate embankment dimensional parameters such as slope angle, berm height, and slope length to reduce erosion of near-surface topsoil.

- Accommodate alternative embankment materials for soil stabilization.

\section{Stationary Target Emplacements}

- Alter embankment designs to accommodate erosion control structures.

- Reformulate embankment dimensional parameters such as slope angle, berm height, and slope length to reduce erosion of near-surface topsoil.

- Accommodate alternative embankment materials for soil stabilization.

- Alter target superstructure to improve serviceability. 


\section{Firing Emplacements}

- Develop alternative materials and designs for overpressure blast mats.

- Reinforce superstructure to improve vehicle collision resistance.

- Reformulate embankment dimensional parameters such as slope angle, berm height, and slope length to reduce erosion.

- Reduce the amount of rock riprap used to stabilize the embankment.

\section{Range Structure Profile Analysis}

- Integrate embankment structures into the topography to create a more realistic training setting using a combination of vegetation and earthwork.

- Reduce embankment slope length through erosion control practices.

- Reduce embankment profile.

\section{Soil and Water Conservation Implementation}

- Develop guidelines for a range-wide erosion control plan during the range build phase.

- Develop maintenance guidelines to implement erosion control practices during range reconstruction periods.

- Develop instructions to repair embankments and erosion control structures after training exercises. 


\section{Range Monitoring Case Study: Camp Atterbury, Indiana}

The purpose of the installation investigations discussed in this report was to identify range design limitations and develop new/modified guidelines that can be implemented into existing range design guidelines. The design suggestions aim to enhance environmental compliance on military installations in a manner that lengthens the range maintenance interval, reduces the overall cost, and enables improved military training. To develop a design methodology to meet these goals requires qualitative and quantitative data collection on military training at Army installation ranges. A qualitative data analysis of the installation information was performed in Chapter 3. This chapter discusses range monitoring efforts at one military installation: Camp Atterbury, IN. Data collection efforts will be discussed for this installation and pertinent engineering data will be analyzed to determine the engineering parameters of a recently built MPTR. Once the engineering properties of this range have been ascertained, the range design will be reworked to develop a design methodology to assist in the development of new/modified guidelines.

To facilitate data collection at this installation, a comprehensive range monitoring effort was initiated. This initiative included an erosion monitoring plan. The range monitoring period began in November of 2003 and terminated in December 2004. Soil engineering properties were calculated using the erosion monitoring dataset; range design guideline parameters will be extracted from this information.

\section{Range Monitoring Goals}

The monitoring goals were:

- Develop a framework for assessing erosion and its relation to military training.

- Collect and interpret pertinent information concerning erosion on military ranges.

- Use this information to support the development of range design guidelines that enhance environmental compliance, increase maintenance intervals, and enable military training. 


\section{Background}

Atterbury Reserve Forces Training area is an Indiana National Guard and United States Army Reserve training facility that accommodates multi-organizational training for military forces, state police, and local police. Camp Atterbury, established in 1942, is located in south-central Indiana approximately $64 \mathrm{~km}$ (40 miles) south of Indianapolis.

Nearby cities and towns include Edinburgh (population 4,505), less than $5 \mathrm{~km}(3$ mi) east; Nineveh, less than $1.6 \mathrm{~km}$ (1 mi) northwest; Franklin (population 19,463), about $16 \mathrm{~km}$ (10 mi) north; and Columbus (population 39,059), about $9.6 \mathrm{~km}$ (6 mi) southeast. Small, rural communities surround Princes Lakes, Cordry Lake, and Sweetwater Lake along the western boundary. The 1990 population density of the rural communities near Camp Atterbury was 100 to 800 people per square mile (Indiana Business Research Center 2000).

The installation encompasses approximately $135.6 \mathrm{~km}^{2}$ (33,500 acres), measures nearly $19.4 \mathrm{~km}$ (12 mi), north-to-south, and is $11.3 \mathrm{~km}$ (7 miles) wide, east-to-west, at the widest point. Centrally located within the installation is the impact area, a $24.3-\mathrm{km}^{2}$ (6,000-acre) expanse of low-lying outwash and steeply sloped forested hills where ordnance used in training impacts the ground (see Figure 17). Land cover in the study area was forest and woodland (53 percent), shrubland (24 percent), and grassland (15 percent); the remaining land cover was sparsely vegetated or water (Risch 2004).

The Atterbury Reserve Forces Training Area offers multiple locations for military commanders to train their troops in infantry and mechanized operations on company, battalion, and brigade scales. Varied terrain and vegetation provide opportunities for all forms of offensive and defensive tactical maneuvering. The installation has ranges available for air assault, ground reconnaissance, and other specialized training operations. From small caliber weapons to mechanized artillery, the Camp Atterbury Joint Maneuver Training Center (CAJMTC) provides numerous ranges designed to support the training needs and weapons systems of the military today. A new range, the MPTR, Range 37, was added to the facility in 2003 to support future force needs and is a major focus of the installation monitoring efforts. 


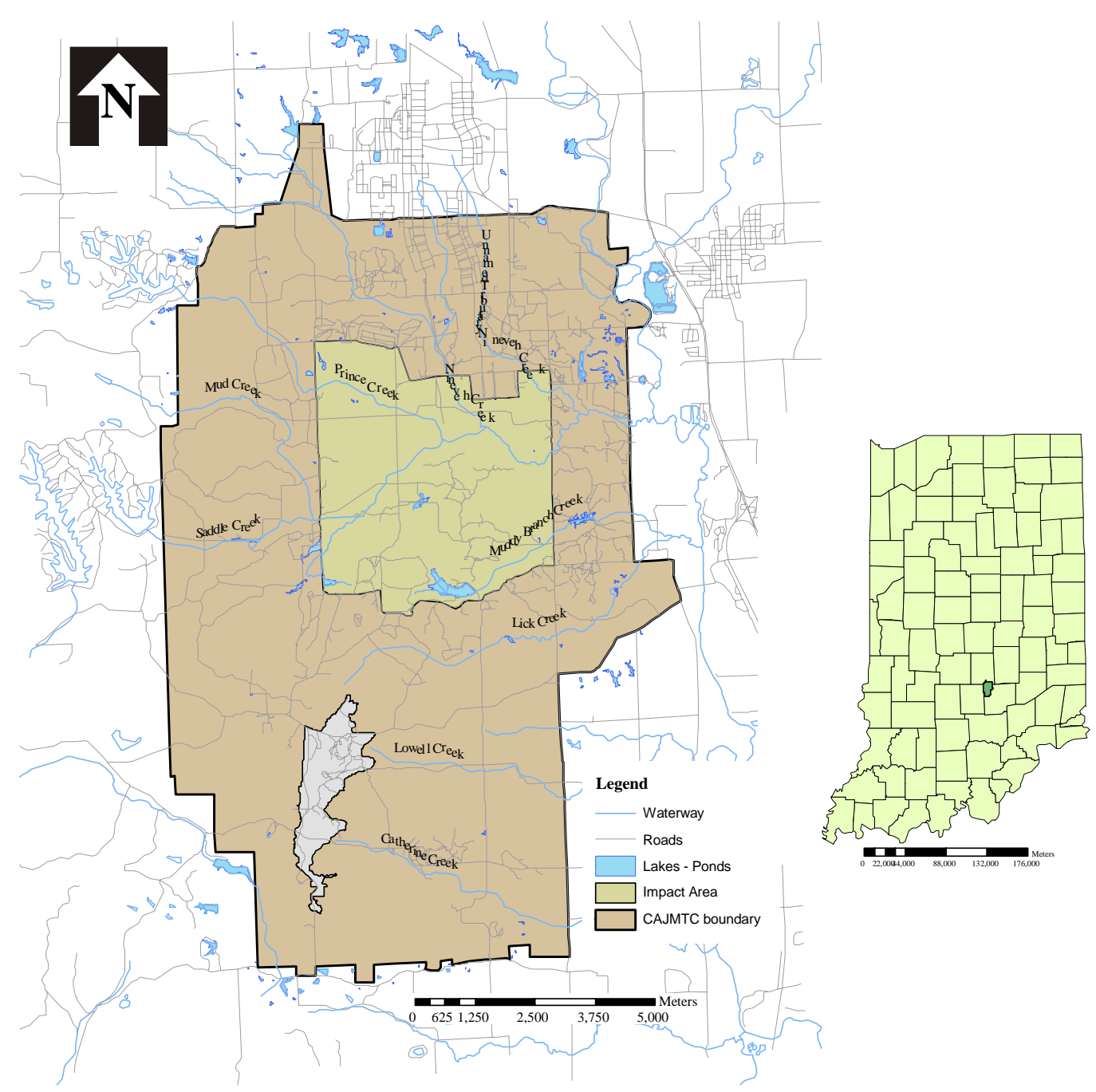

Figure 17. Camp Atterbury Joint Maneuver Training Center, IN.

Construction began on the MPTR, Range 37, in 1998 to extend the military training capabilities of the CAJMTC for tanks, attack helicopters, infantry fighting vehicles, and dismounted infantry. The range, completed in 2003, became active in April 2004 and is located in the southwest sector of the installation. The MPTR includes a support area, a firing area, and a target area. The support area is where training is monitored and equipment and troops are deployed into the range. The firing area is where weapons are positioned and triggered and includes defilade positions, stationary targets, and moving targets for mechanized artillery vehicles. The target area contains stationary and moving targets for weaponry and firing points are oriented to provide northeasterly trajectories into the impact area. The MPTR occupies over $3 \mathrm{~km}^{2}$ (750 acres) in steep partially forested uplands. Monitoring Range 37 provides a unique opportunity to study military training effects from the onset of range activation and the effectiveness of post-construction re-vegetation efforts. The results of monitoring the MPTR will be combined with the monitoring results of the installation. 
Although smaller than the other installations visited for the overall research study, Camp Atterbury conducts military training in a manner consistent with the majority of DoD installations found in mesic environments. In addition, the close proximity of the University of Illinois at Urbana-Champaign to Camp Atterbury made this installation the ideal location to conduct range monitoring. Over the course of a year, the research team has collected data on current range conditions, quantified embankment erosion, and determined sediment and heavy metal concentrations through range monitoring.

\section{Camp Atterbury Soils}

The soils in this area are classified as discontinuous loess on bedrock. Soil surveys completed on the installation classify the area into two main soil associations: Pekin-Chetwynd-Bartle (well drained) and Crosby-Miami-Rennselaer (poorly drained). Both are finely textured soils. Pekin-Chetwynd-Bartle soil associations consist of ridgetop soils and steep side slopes on terraces along streams. The land use for this soil association is primarily woodlands and pasture. Crosby-Miami-Rennselaer soil associations consist of soils on broad flats, knolls, ridges, and side slopes on till plains and terraces; the land use is primarily military training or idle (Noble et al. 1990). A detailed description of the soil survey information for the MPTR area fol-

lows. Soil information was taken from the soil survey of Brown County and part of Bartholomew County.

Range 37 Soils

Be - Beanblossom channery silt loam, occasionally flooded

Bg F - Berks-Trevlac-Wellston complex, 20 to 70 percent slopes

Bn D2 - Bonnell loam, 12 to 20 percent slopes, eroded

Bp D3 - Bonnell clay loam, 12 to 20 percent slopes, gullied

Cn C2 - Cincinnati silt loam, 6 to 12 percent slopes, eroded

Hk F - Hickory silt loam, 20 to 70 percent slopes

Pe B - Pekin silt loam, 2 to 6 percent slopes

TIB - Tilsit silt loam, 2 to 6 percent slopes

We C2 - Wellston-Gilpin silt loams, 6 to 20 percent slopes, eroded

\section{Study Site Armor Moving Target Emplacement Soils}

Be - Beanblossom channery silt loam, occasionally flooded

Bg F - Berks-Trevlac-Wellston complex, 20 to 70 percent slopes

Hk F - Hickory silt loam, 20 to 70 percent slopes

We C2 - Wellston-Gilpin silt loams, 6 to 20 percent slopes, eroded

The predominant soil textural type for the range and embankment area is silt loam with occasional areas of complex soils. However, the range designer should be fa- 
miliar with all specific soil types as there is a great likelihood that range elements will be constructed upon or constructed with these soils.

\section{Camp Atterbury Hydrology}

The Camp Atterbury Reserve Force Training Area is located within the East Fork of the White River basin. The watersheds of this basin follow the general topography of the region moving eastwardly across the installation. The majority of installation streams flow into Driftwood River and eventually into the East Fork of the White River. Three of the eight monitored streams, Lick Creek, Catherine Creek, and the Muddy Branch have their headwaters within Camp Atterbury. The other streams, Prince Creek, Nineveh Creek, Mud Creek, and Saddle creek and an unnamed tributary to the North Branch of Nineveh Creek originate off-post. All streams in the study area, with the exception of Nineveh Creek are first order streams with drainage areas less than $25.9 \mathrm{~km}^{2}$ (10 sq mi, Risch 2004). Furthermore, past studies conducted throughout the White River Basin by Schnoebelen and others (1999) report that streams located in soil regions having thicker glacial deposits over bedrock have longer sustained base-flow in times when precipitation does not occur as compared to soil regions of thin glacial deposits in steeply sloped areas. Observations of stream flow from field visits at Camp Atterbury during the study period corroborate this position. Streams located in the northern half of the installation have a tendency to have base flow even during long periods of dry weather. Streams located in the southern half of the installation are more susceptible to extended periods without flow as the topography is more steeply sloped and the soil deposits thin.

\section{Range Monitoring Methods and Materials}

\section{Erosion Monitoring}

A conceptual model of erosion and sediment transport was adopted to assist in the qualitative and quantitative interpretation of range monitoring information. The processes of soil loss, soil deposition, and soil transport have been intensively studied and mathematical models have been formulated to describe the processes. Soil loss, deposition, and movement are phenomena generated by natural or anthropomorphic processes. Wind, water, and human interference are the main influential forces affecting the erosion cycle on a military installation. The erosion study will focus on the soil erosion/deposition/movement processes resulting from rainfall, water runoff, and human interference. The effects of wind erosion are minor at the study site and were not investigated. Additionally, range structures optimized to resist erosion by water will also resist wind erosion. 
The cycle of erosion by water begins when rainfall strikes the earth. Raindrop or splash erosion as this phase is called varies as a function of precipitation intensity and is the predominant soil displacement force during the initial stages of a rain event. During splash erosion, soil is dislodged and the soil surface structure is changed. Rainfall begins to infiltrate the soil and much of the rainfall seeps into the ground. The movement of water into the ground is dependent on antecedent soil conditions and rainfall intensity. After a time, ponding on the soil surface occurs and runoff begins. Water immediately moves down slope as sheet flow. Finer soil particles loosened by the rainfall are suspended in the flow and are transported with the water. The process of sheet flow and similarly sheet erosion is highly conceptualized and exists only briefly as water tends to immediately channel and form rills. Therefore, splash erosion and sheet erosion processes are often combined into the area of interill erosion. Watson and Laflen (1986) expressed the interill process as:

$$
D=K i^{2} S
$$

[Equation 1]

Where:

$\mathrm{D}=$ interill erosion rate in $\mathrm{kg} / \mathrm{m}^{2}-\mathrm{s}$

$\mathrm{K}=$ interill erodibility of soil in $\mathrm{kg}-\mathrm{s} / \mathrm{m}^{4}$

$\mathrm{I}=$ rainfall intensity in $\mathrm{m} / \mathrm{s}$

$\mathrm{S}=$ slope factor $=1.05-0.85 \exp (-4 \sin \theta)($ Liebnow et al. 1990$)$, and $\theta=$ slope in degrees.

As a storm event progresses the impact energy of rainfall is diminished by sheet flow and rainfall erosion is replaced by sheet erosion as the prevalent erosion force. As mentioned previously, the process of sheet erosion is very brief for the surface tension forces of water concentrate the flow and rill erosion begins. The energy of this converging water is greater than that of sheet flow and therefore during rill erosion there is a greater capacity for soil transport and larger particle sizes in the flow. As rill erosion continues, preferential flow pathways develop in the soil. At this stage, soil loss is attributed to the contributions from sheet erosion and rill channelization in areas of substantial flow. Lane et al. (1987) outlined the process of rill erosion that has been expressed as:

$$
D=K\left(\tau-\tau_{c}\right)\left(1-\frac{Q}{T}\right)
$$

[Equation 2]

Where:

$\mathrm{D}=$ rill attachment rate in $\mathrm{kg} / \mathrm{m} 2-\mathrm{s}$

$\mathrm{K}=$ rill erodibility resulting from shear in $\mathrm{s} / \mathrm{m}$

$\mathrm{T}=$ critical shear below which no erosion occurs in $\mathrm{Pa}$

$\mathrm{Q}=$ rate of sediment flow in the rill in $\mathrm{kg} / \mathrm{m}-\mathrm{s}$

$\mathrm{T}=$ sediment transport capacity of rill in $\mathrm{kg} / \mathrm{m}-\mathrm{s}$

$\tau=$ hydraulic shear of flowing water in $\mathrm{Pa}=\rho$ grs 


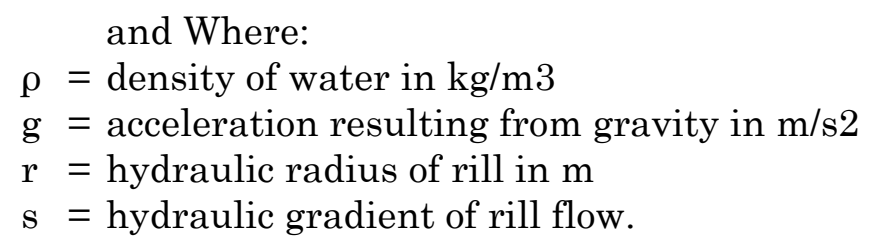

As the flow pathways get larger rill erosion becomes gully erosion. The process of gully erosion depends on multiple parameters that may occur separately or simultaneously and the processes are not well defined (Schwab et al. 1993). However, gully erosion is analogous to rill erosion occurring at a much larger scale. At this stage of the erosion cycle much of the soil loss is observed in areas near the gully, as the energy of the flow of water is substantial enough to move larger soil particle sizes. Over time, soil from upland areas moves over the landscape from rills and gullies to streambed channels. It is important to note that the stages described above do not fully explain the entire process of soil movement, for only soil erosion has been mentioned. The cycle of soil disturbance, soil erosion, sediment transport and soil deposition is extremely complex. Equations [1] and [2] represent theoretical erosion soil loss rates and allow the calculation of potential soil loss over time. The ability of water to transport sediment downhill has been estimated by Foster and Meyer (1972) as:

$$
T=B \tau^{1.5}
$$

[Equation 3]

Where:

$\mathrm{T}=$ transport capacity per unit width in $\mathrm{kg} / \mathrm{m}-\mathrm{s}$

$\mathrm{B}=$ transport coefficient based on soil and water properties

$\tau=$ hydraulic shear of the rill channel in Pa.

The measurement of erosion is a time-consuming process as the quantification of soil movement requires repetitious measurements over a specified monitoring period. To ease this process, a simple method of reconnaissance, the erosion pin method, was adopted to estimate erosion levels occurring on moving target emplacements. Additionally, soil physical properties for Range 37 were determined using particle size analysis (PSA), the Atterberg limits and soil penetration resistance. Additional parameter measurements included percent vegetation coverage, site precipitation, and training range activity.

To assist in embankment soil loss estimations, a process based erosion prediction model, Watershed Erosion Prediction Project (WEPP), was used to simulate erosion from berm conditions. This study applied the hillslope application of this modeling program to determine the longevity of a moving target emplacement under given field conditions (WEPP 2005). Field collected data were used to calibrate the model, 
and then the calibrated model was used for annual soil loss estimation and useful life expectancy of the embankments.

\section{Erosion Pin Method}

A moving target emplacement on Range 37 was chosen to monitor embankment face erosion. This embankment was selected on the basis of berm height, slope, and embankment slope length, $18 \mathrm{~m}$ (59 ft), 31 percent (3.2:1), and $64 \mathrm{~m}$ (210 ft), respectively. Additionally, it was decided that the low level of embankment face vegetation was characteristic of highly used range structures and would be representative of embankment erosion potential on other installations. A study plot was established on the embankment face in the area shown in Figure 18. The measurement of soil loss, soil movement, and soil deposition was monitored using a modified erosion pin method of Haigh (1977), Martin (1996), and the United Nations Food and Agricultural Organization (FAO 1997). This method is an effective way to quickly gauge the spatial characteristics of erosion on the embankment and determine overall soil loss from the field. The erosion pins were small stainless steel stakes 50 to $75 \mathrm{~cm}$ in length and $3 \mathrm{~mm}$ in diameter see Figure 19. Additionally, the stakes were graduated for easy measurement. Forty stakes were placed on the embankment face in a grid pattern like the one shown in Figure 19 to directly measure soil loss from the study plot. Measurement of soil movement was achieved using a graduated pin and periodically taking a digital image of each pin. The digital photographs, the small pin diameter, and the graduated markings on the erosion pins reduced soil disturbance in the areas surrounding the pin that would be associated with direct measurement. These images were catalogued and stored for later analysis of soil movement within the study plot.

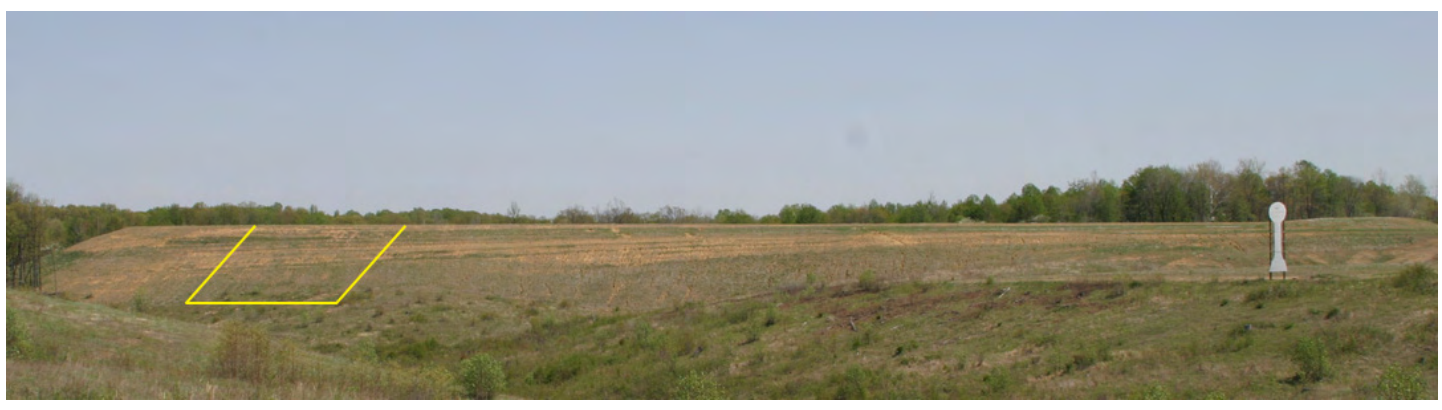

Figure 18. Erosion pin plot on moving target embankment.

Images in Figure 19 illustrate the pin and the study plot layout $\left(2018 \mathrm{~m}^{2}\right)$. Estimation of soil movement using erosion pins was based on the assumption that a uniform erosion/deposition pattern occurred over the study area. Visual inspections of the plots during data collection periods verified that this assumption was valid mainly for the upper portion of the plot as severe erosion occurred and a large num- 
bers of rills were present at the base of the embankment. However, the uniform soil loss assumption underestimated the severity of erosion. Therefore, the grid sizes were reduced at the base of the embankment thus improving the soil loss estimation. Erosion pin measurements occurred over 135 days from 31 March 2004 to 16 July 2004. This period covered the majority of the rainy season at this site, and therefore, the worst-case scenarios for the erosion processes should have been captured during this period. Termination of the erosion monitoring occurred to facilitate berm maintenance and rehabilitation on the embankment during July 2004.
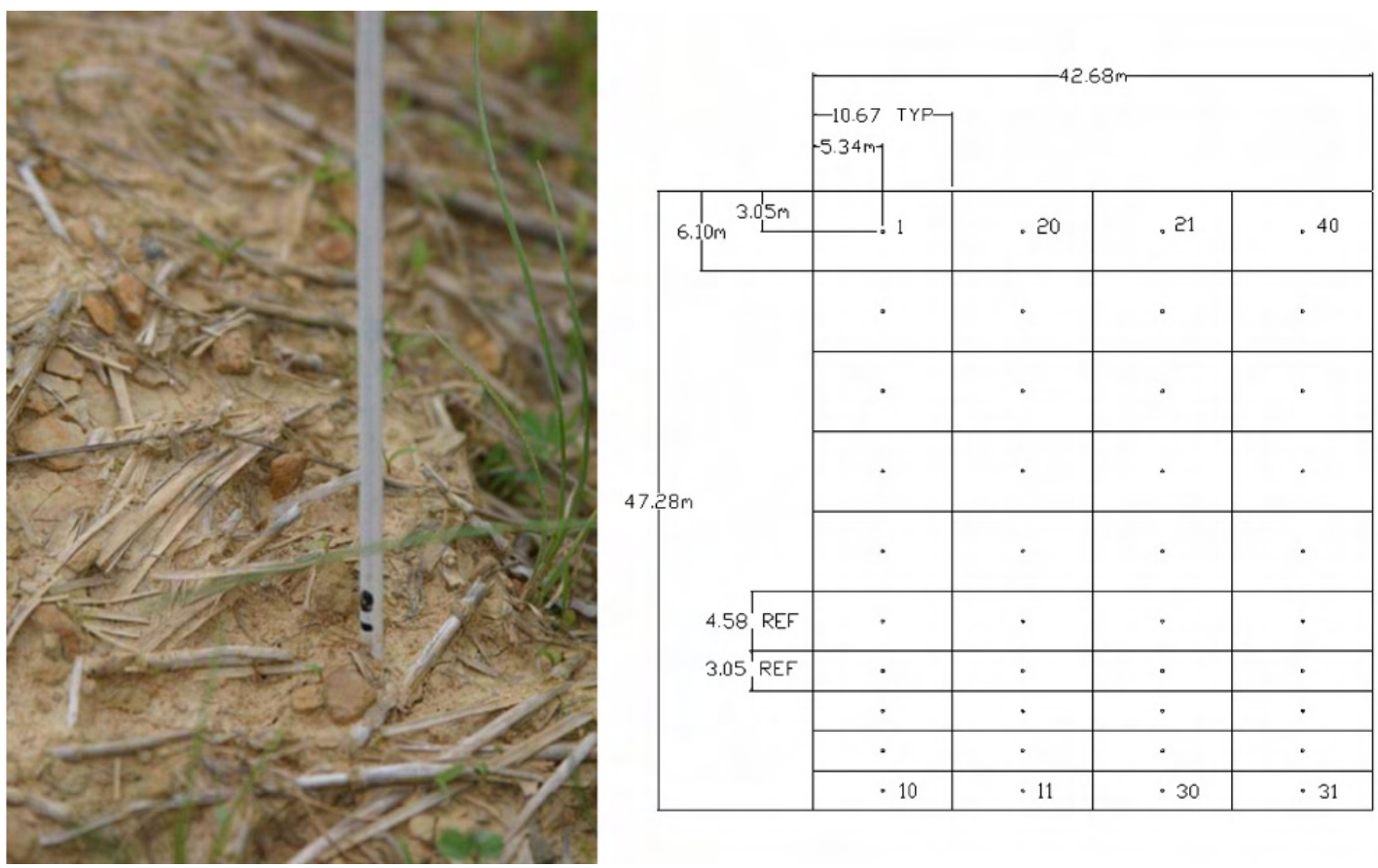

Figure 19. Erosion pin and erosion pin layout.

\section{Particle Size Analysis}

The classification of Camp Atterbury soils, based on particle size, was completed to determine the engineering properties of soils present on Camp Atterbury ranges. Soil samples from several areas on Range 37 were collected and transported to a laboratory facility where the PSA was performed in accordance with U.S. Army Corps of Engineers specifications (USACE 1970).

\section{Plastic and Liquid Limits Analysis}

The desired engineering properties of Camp Atterbury soils cannot be found using PSA only. Therefore, the Atterberg limits of the soil are used in addition to PSA to determine the engineering suitability of a soil. The plastic and liquid limits test specified in by USACE (1970) is a suitable method to complement the PSA and is similar to standards of the American Society for Testing and Materials (ASTM 
D4318-00) 2005). Analyses were performed on three Camp Atterbury soil samples taken from the moving target embankment.

\section{Soil Resistance Sampling}

Soil compaction measurements were made using a soil penetrometer at the study plot embankment and near surface soil $(0 \mathrm{~cm}-45 \mathrm{~cm})$. A Fieldscout SC 900 Soil Compaction Meter measured soil compaction. This instrument was used following methods in accordance with American Society of Agricultural Engineers* standards for soil cone penetrometer. Data reporting followed ASAE standards for procedures for using and reporting data obtained with a soil cone penetrometer (ASAE 1999a, 1999b).

\section{Vegetation Measurements}

Estimations of vegetation coverage were facilitated by image analysis software, ASSESS, and high-resolution digital images of the embankment face (Lamari 2002). ASSESS uses spectral hue analysis algorithms to analyze a digital image and determine the areal percentage of values within a user-specified spectral range. The software manual offered a guideline range for the analysis of vegetation. Additionally, researchers at ERDC-CERL offered analysis insights as to correct spectral range values based on assessments at other installations to estimate accurate vegetation coverage for the moving target embankment at Camp Atterbury (professional communication, Michael Denight, environmental biologist, ERDC-CERL, 15 April 2005).

\section{Erosion Modeling}

To assist in the development of embankment soil loss estimations, the embankment erosion study modeled berm conditions using a process-based erosion prediction model, WEPP. This study applied the hillslope application of this modeling program to determine the longevity of a moving target emplacement under given field conditions (WEPP 2005). According to WEPP documentation (Flanagan et al. 1995):

The WEPP erosion model computes soil loss along a slope and sediment yield at the end of a hillslope.

\footnotetext{
* The American Society of Agricultural Engineers (ASAE) is now the American Society of Agricultural and Biological Engineers (ASABE).
} 
Interrill and rill erosion processes are considered. Interrill erosion is described as a process of soil detachment by raindrop impact, transport by shallow sheet flow, and sediment delivery to rill channels. Sediment delivery rate to rill flow areas is assumed proportional to the product of rainfall intensity and interrill runoff rate. Rill erosion is described as a function of the flow's ability to detach sediment, sediment transport capacity, and the existing sediment load in the flow.

The hillslope model is suitable to hillslope lengths up to 100 meters. The dimensional parameters of the study embankment fall within this constraint. Field collected data were used to calibrate the model, and then the calibrated model was used to estimate annual soil loss.

\section{Range Monitoring Results}

\section{Range Evaluation Results}

Training ranges vary in size from several hundred square meters to several hundred square kilometers. Typically, the larger ranges have numerous structures erected on the landscape to aid in military training exercises. Two such structures are firing emplacements and targeting emplacements; both incorporate earthen embankments for protection. Optimizing the integrity of these edifices is an important factor in environmental risk reduction.

All observed ranges exhibited some degree of environmental degradation; however, the degradation differed in scale and severity at each range and often varied within a range. The investigators combined field observations, current range design guidelines, and future range proposals to develop a consensus of range design and maintenance issues. These issues mainly address issues at installations in temperate climates. The research team, after analyzing all the observations and discussions, has drawn the following conclusions:

1. Numerous range structures deviated from guidelines as specified in the RETS Range Design Manual and quality control/quality assurance adherence to design criteria was inconsistent. Dimensional parameters frequently deviated from design specifications, inadequate gradient being the most frequently violated parameter. 
2. Poor vegetation and the resultant soil loss problems were identified at all training ranges and at all visited installations. Ranges receiving the greatest level of training activity had severe localized erosion and vegetation problems. Firing points, trails, target emplacements, and staging areas had the greatest concentrations of problems.

3. Poor siting of range structures were significant impediments to sustainable range maintenance that increased both design and maintenance costs.

4. The range structure profile blends inadequately with the surrounding landscape and permits effortless identification of critical training elements. Heavily used and inadequately maintained range structures reduce training effectiveness (e.g., bare soil on target positions allow trainees to identify readily improperly sited target positions, thereby reducing the element of surprise).

5. Early problem identification is critical for cost-effective erosion control. Current procedures function to identify existing problems, but do not anticipate future problems.

\section{Embankment Evaluation Results}

The erosion experimental plot yielded a significant soil loss over the study period. A large variability in soil movement was observed over the plot area, but overall the plot exhibited a very high cumulative soil loss during the study period. Monitoring of soil loss (+) and deposition (-) over 135 days resulted in $15.7 \mathrm{~m}^{3}$ of measured cumulative soil loss. Unfortunately, the study was terminated earlier than expected as severe erosion conditions compromised berm utility and required extensive maintenance at that point. Vegetation and soil characteristics were similar over the entire embankment face during the study period. Estimation of vegetative cover using digital photographs taken during the monitoring period with ASSESS ranged from 39 percent to 50 percent and averaged 43 percent during this period.

Table 1 lists the range activity over the monitoring period from April 2004 through July 2004. This level of range activity is moderate in comparison to activities that normally occur at other installations. The bulk of the soil displacement on the experimental embankment mainly depended on the action of natural forces (rainfall amount and intensity). The data in Table 1 separates mechanized ordnance from the bulk ordnance quantity as moving target emplacements are the main targeted structures for mechanized ordnance and activity. The total berm face area occupies $68 \mathrm{~km}^{2}$ (about 16.8 acres) of the $3500-\mathrm{km}^{2}$ (865-acre) MPTR or 2.2 percent of the study range, while the moving berm face area occupies 95 percent of the total berm face area. Assuming that soil loss is similar on each embankment face and that all berms receive equivalent levels of training activity, training rounds fired per unit of soil loss from total and mechanized ordnance is 279 rounds $/ \mathrm{m}^{3}$ and 127 rounds $/ \mathrm{m}^{3}$, respectively. 
Table 1. Estimated soil loss from military target embankments at $\mathbf{4 3}$ percent vegetation cover.

\begin{tabular}{||l||l||}
\hline Total ordnance rounds fired & 147810 \\
\hline \hline Mechanized ordnance rounds fired & 66902 \\
\hline \hline Total rounds fired $/ \mathrm{m}^{3}$ berm soil lost & 279 \\
\hline \hline Mechanized rounds fired $/ \mathrm{m}^{3}$ berm soil lost & 127 \\
\hline \hline
\end{tabular}

Particle size analysis of the embankment soil yielded the sand, silt, and clay percentages of 75 percent, 20 percent, and 5 percent, respectively. The effective size (diameter), D10, of the soil was $0.04 \mathrm{~mm}$ and the uniformity coefficient (CU = D60/D10 ) was 7. According to these analyses, soils at this site are classified as sandy silts or sandy clays. These results were confirmed by the soil survey analyses conducted at Camp Atterbury. Based on knowledge of the practices used during construction of the MPTR at Camp Atterbury (i.e., homogenous fill, minimal topsoiling), it is known that samples taken from the near surface are indicative of embankment soil composition throughout the structure.

Testing of the Atterberg limits on three soil samples obtained from the moving target embankment yielded the results shown in Table 2. Based on soil plasticity charts, these soils are inorganic clays of medium plasticity and inorganic silts (CLML) of medium compressibility and moderate cohesion. The dry strength for these soils is medium and the angle of internal friction, $\varphi$, for such soils often range from $25^{\circ}$ to $35^{\circ}$ (Technical Manual 5-818-1/Air Force Manual 88-3 1983). As stated previously, the three soil samples were collected from the near-surface profile. In situ soil compaction increases the geometric interference of soil particles, thereby increasing the internal angle of friction.

Table 2. Atterberg limits for moving target embankment soils.

\begin{tabular}{|l|l|l|l|}
\hline Soil Core Samples & Liquid Limit & Plastic Limit & Plasticity Index \\
\hline Embankment Soil Core 1 & 34 & 20 & 14 \\
\hline Embankment Soil Core 2 & 32 & 26 & 6 \\
\hline Embankment Soil Core 3 & 39 & 31 & 8 \\
\hline
\end{tabular}

Figure 20 illustrates soil resistance data collected from the north embankment plot on 10 March 2004 at the onset of monitoring. Soil moisture analysis of samples taken at the time of testing indicated a soil moisture content of 14 percent by weight. 


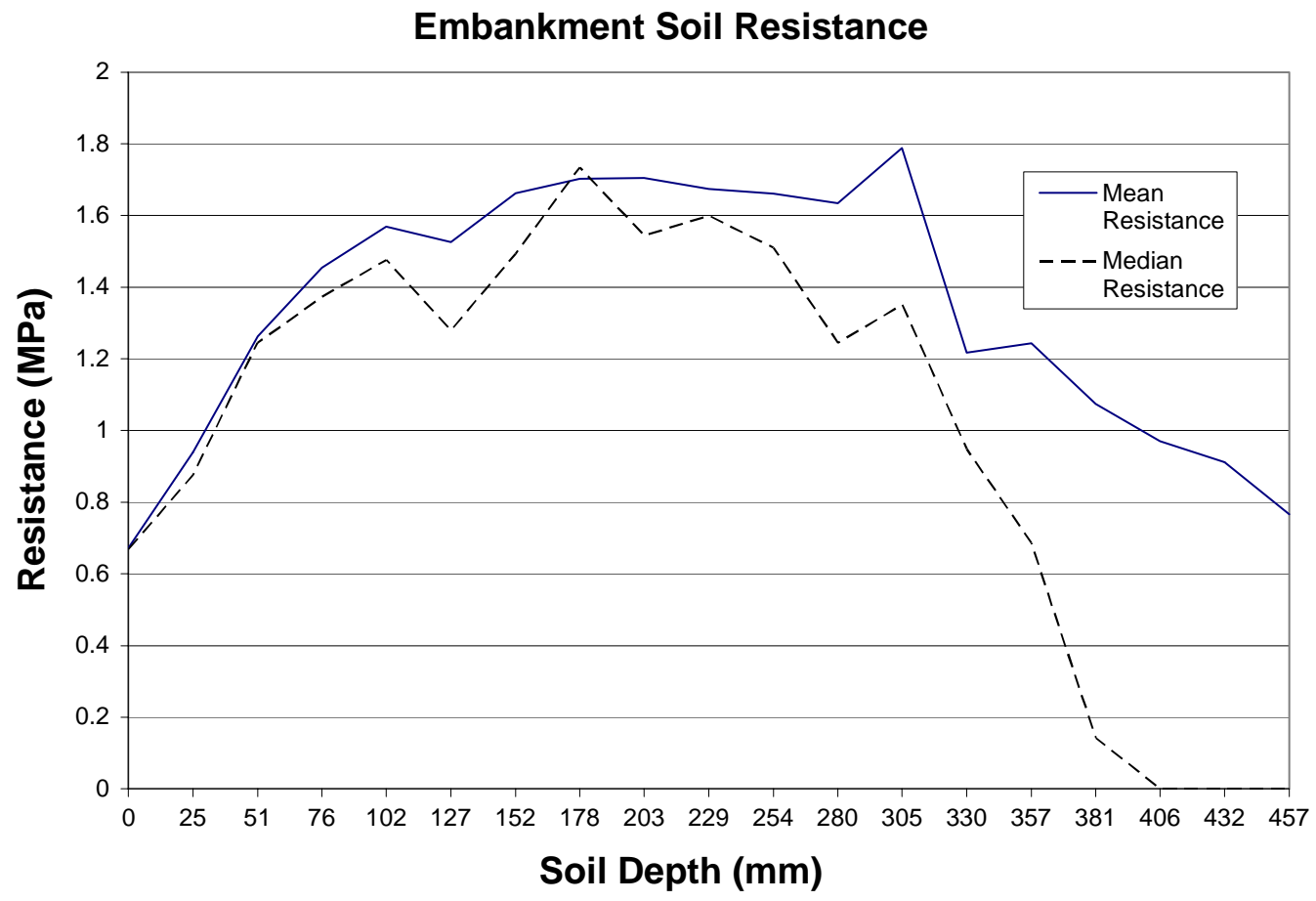

Figure 20. Soil resistance data from embankment study plot.

Soil penetrometer readings taken at 40 grid locations revealed surface and nearsurface soil compaction. The mean soil resistance increased to a maximum $1.8 \mathrm{MPa}$ (megapascals) at a depth of $30 \mathrm{~cm}$ and the median soil resistance increased to a maximum $1.7 \mathrm{MPa}$ at a depth of $17.5 \mathrm{~cm}$ for the study plot. Soil compaction below $30 \mathrm{~cm}$ depth dropped dramatically in the soil for the median and the mean soil resistance. The measurements taken on this embankment suggest that adequate compaction did not occur in soil depths below $30 \mathrm{~cm}$. This finding was unusual because soil resistance should remain constant or increase at depths greater than 30 $\mathrm{cm}$. This indicates that, during construction, proper soil compaction was not achieved for this embankment.

Analysis of the embankment data provided useful information for WEPP model calibration and utilization. A hillslope model matching soil, vegetation, slope, and climate conditions during the study period estimated an annual sediment yield of $253 \mathrm{Mg} / \mathrm{ha}$ for 2004. This high level of erosion is 23 times greater than the tolerable annual soil loss rate of $11 \mathrm{Mg} / \mathrm{ha}$ for local soils. Simulation runs for periods of 30 years generated sediment yields of $510 \mathrm{Mg} / \mathrm{ha}$ per year.

Based on the dimensional characteristics specified in the manual for the design of RETS ranges, the embankment top portion can withstand $76 \mathrm{~mm}$ of soil loss before the embankment superstructure is exposed. Using this constraint as a guide, an equation was developed using acceptable embankment soil loss, bulk density, and 
annual soil loss. The embankment life expectancy can be determined using the following equation:

$$
\text { Embankment Life (years) }=\frac{S\left(10000 m^{2} / h a\right) \rho_{b}}{A}
$$

Where:

$\mathrm{S}=$ acceptable soil loss depth (meters) from the embankment until failure $\mathrm{A}=$ annual soil loss $(\mathrm{Mg} / \mathrm{ha} / \mathrm{yr})$ from the embankment $\rho b\left(\mathrm{Mg} / \mathrm{m}^{3}\right)=$ the bulk density of the soil.

Using the values from the 1-year and 30-year WEPP simulations to determine annual soil loss, the useful embankment life was estimated to range from 2.1 years ( $\mathrm{S}$ $=0.076 \mathrm{~m}, \rho \mathrm{b}=1.45 \mathrm{Mg} / \mathrm{m} 3, \mathrm{~A}=510 \mathrm{Mg} / \mathrm{ha} / \mathrm{yr})$ to 4.4 years $(\mathrm{S}=0.076 \mathrm{~m}, \rho \mathrm{b}=1.45$ $\mathrm{Mg} / \mathrm{m} 3, \mathrm{~A}=253 \mathrm{Mg} / \mathrm{ha} / \mathrm{yr}$ ), respectively. In reality, major rehabilitation of the embankment at this site occurred in August/September 2004, approximately 3 years after construction. Based on this example, the useful embankment life equation is a realistic estimate for major embankment maintenance requirements.

Combining the results of the previous sections for particle size analysis, liquid and plastic limit analysis, vegetative cover analysis, soil compaction, and soil loss of the study plot, the following comments can be made. The large estimated soil loss of $253 \mathrm{Mg} / \mathrm{ha} /$ year is attributable to the soil properties, vegetative cover, and areal topography. The slope averaged 32 percent and the vegetative cover was poor. Particle size analysis indicated an effective particle size of $0.04 \mathrm{~mm}$ and a coefficient of uniformity, $\mathrm{CU}=7$, suggesting moderately permeable and poorly graded surface soils. The penetrometer readings suggested a reasonably good level of compaction between $5 \mathrm{~cm}$ and $30 \mathrm{~cm}$ and indicated a region of significantly less shear strength below $30 \mathrm{~cm}$ soil depth. The Atterberg limit tests suggest that the soil can be successfully compacted to standard maximum dry densities with high stability (large $\varphi)$. The embankment soil composition suggests that the subsurface compaction of soils is easily achievable. However, these soils are highly susceptible to surface degradation and the slope angle considerations for the subsurface differ from the surface. Subsurface compaction of embankment soils achieving at least 90 percent of the optimum moisture-density relationship would permit the use of 3:1 embankment slopes, but surface composition requirements dictate the use of a lesser (flatter) slope to reduce erosion potential especially where vegetation cover is poor. Visual inspections of the embankment and the high estimate of annual soil loss corroborate this statement. 


\section{Berm Design}

\section{Embankment Soil Loss, Slope, and Vegetative Coverage}

Using the information presented in the previous section, a moving target emplacement model for Camp Atterbury was developed using the physical properties determined in the previous section. To discern the impact of implementing erosion control and embankment stabilization practices, this model was manipulated to compare current soil loss of existing practices to the expected soil loss using erosion control techniques. The current embankment parameters, slope, slope length, vegetative cover and conservation practice were examined to determine the effect on soil loss.

The Universal Soil Loss Equation (USLE) and the Revised Universal Soil Loss Equation (RUSLE) continue to be widely accepted methods for estimating sediment loss. The use of these equations complements the findings estimated by WEPP and more clearly illustrate the factors that contribute to erosion phenomenon on embankments. Additionally, they are useful for determining the adequacy of conservation measures.

The average annual soil loss, determined by Wischmeier and Smith (1978) is estimated by the equation:

$$
A=R K L S C P
$$

[Equation 5]

Where:

$\mathrm{A}=$ average annual soil loss in $\mathrm{Mg} / \mathrm{ha}$

$\mathrm{R}=$ rainfall and runoff erosivity index for geographic location (Figure 5.5. Schwab et al. 1993)

$\mathrm{K}=$ soil erodibility factor

$\mathrm{L}=$ slope length factor

$\mathrm{C}=$ cover management factor

$\mathrm{P}=$ conservation practice factor.

The values for rainfall and runoff erosivity index are determined by the equation,

$$
K=2.8 \times 10^{-7} M^{1.14}(12-a)+4.3 \times 10^{-3}(b-2)+3.3 \times 10^{-3}(c-3) \text { [Equation 6] }
$$


Where:

$\mathrm{M}=$ particle size parameter (\% silt $+\%$ very fine sand $) \times(100-\%$ clay $)$

$\mathrm{a}=$ percent organic matter

$\mathrm{b}=$ soil structure code (very fine granular, 1; fine granular, 2; medium or coarse granular, 3; blocky, platy, or massive, 4)

$\mathrm{c}=$ profile permeability class (rapid, 1 ; moderate to rapid, 2 ; moderate, 3 ; slow to moderate, 4; slow, 5; very slow, 6).

The value for $\mathrm{L}$, the slope length factor is determined by the equation,

$$
L=(l / 22)^{m}
$$

[Equation 7]

Where:

$\mathrm{L}=$ slope length factor

$\mathrm{l}=$ slope length in $\mathrm{m}$

$\mathrm{m}=$ dimensionless coefficient.

McCool et al. (1989) recommended that for conditions where rill erosion and interrill erosion were about equal on a standard 9 percent slope and 22-m slope length, then $\mathrm{m}$ could be found by the equation:

$$
m=\frac{\sin \theta}{\sin \theta+0.269(\sin \theta)^{0.8}+0.05}
$$

[Equation 8]

Where:

$\theta=$ field slope steepness in degrees $=\tan ^{-1}(\mathrm{~s} / 100)$

$\mathrm{s}=$ field slope in percent.

For conditions where rill erosion is greater than interrill erosion (like soils with large silt or fine sand content), $\mathrm{m}$ should be increased up to 75 percent. Where rill erosion is less than interrill erosion (on short slopes or high clay content soils), $\mathrm{m}$ should be decreased down 50 percent.

McCool et al. (1987) established S factors for slope steepness.

For slopes shorter than $4 \mathrm{~m}$,

$\mathrm{S}=3.0(\sin \theta)^{0.08}+0.56$

For slopes longer than $4 \mathrm{~m}$ and $\mathrm{s}<9$ percent, $\mathrm{S}=10.8 \sin \theta+0.03$

For slopes longer than $4 \mathrm{~m}$ and $\mathrm{s} \geq 9$ percent, $\mathrm{S}=16.8 \sin \theta-0.50$.

For the purposes of this analysis, the values obtained for the soil loss factors, $\mathrm{P}, \mathrm{R}$ and $\mathrm{K}$ are as follows: 
$\mathrm{P}=1$ (No conservation practices),

$\mathrm{R}=3200 \mathrm{MJ}-\mathrm{mm} / \mathrm{ha}-\mathrm{h}-\mathrm{yr}$ for geographic location of Camp Atterbury (Schwab et al. 1993), $\mathrm{K}=0.0279$.

The factors R, K are static as they are functions of the geographic location of the installation. Additionally if no conservation practices are adopted then the factor $\mathrm{P}$ remains equal to one. The slope length factor, LS was calculated using the dimensional parameters of the modeled moving target embankment using equation 7 and the S-factors for slope steepness,

$$
\begin{aligned}
& \mathrm{L}=(1 / 22)^{\mathrm{m}}=(64 / 22)^{0.67}=2.05 \\
& \mathrm{~S}=16.8 \sin \theta-0.50=16.8 \sin (18.26)-0.50=4.7 \\
& \mathrm{LS}=2.05(4.7)=9.63
\end{aligned}
$$

Using the value of A obtained from the WEPP simulation and rearranging equation 5 , the factor $\mathrm{C}$ can be determined.

$$
C=\frac{A}{R K P L S}=\frac{253}{(3200)(0.0279)(1)(9.63)}=0.29
$$

The cover management factor, $\mathrm{C}=0.29$ ( $~ 70 \%$ vegetative cover $)$ is undoubtedly high as field measurement found the actual value to range from $40 \%-50 \%$. This discrepancy is likely due to an underestimation of the erosion at the site, due to the extensive rill erosion at the study site and the method the WEPP model determines soil loss. Regardless, it will be assumed for ease of calculation that the cover management factor, $\mathrm{C}$, is time invariant. The $\mathrm{C}$ factor for bare ground is 1 . The cover management factor, $\mathrm{C}$, is the relation between erosion on bare soil and erosion observed under a vegetative system. An assessment of various slopes and slope lengths will be used to determine how much the annual soil loss values are reduced and whether that reduction is sustainable soil loss.

Altering the current 3:1 embankment slope to 5:1 produces the following estimated annual soil loss, A,

$$
\begin{gathered}
L S=(73.2 / 22)^{0.64}(16.8 \sin (14.036)-0.50=3.57 \\
A=C(R K P)(L S)=0.47(89.28)(3.57)=149 \mathrm{Mg} / \mathrm{ha} / \mathrm{yr}
\end{gathered}
$$

The value of annual soil loss, A, is approximately 3 times less for a 5:1 slope than a 3:1 slope, but still approximately 17 times the amount of the sustainable soil loss 
value of $9 \mathrm{Mg} / \mathrm{ha} / \mathrm{yr}$. A 5:1 slope is prohibitively expensive to construct and space allowances on ranges generally do not permit a 5:1 slope.

Returning to the original embankment dimensions, a 3:1 side slope, a 64-meter slope length, and an 18.3-meter embankment height, the attention shifts to the $\mathrm{C}$ factor and calculations to determine when cover management practices alone will bring the embankment within sustainable soil loss values. Varying the $\mathrm{C}$ factor produces the annual soil loss rates seen in Table 3.

Table 3. Influence of vegetative cover management factor, C, on A, 3:1 slope.

\begin{tabular}{|cccccc|}
\hline $\mathbf{C}$ & $\mathbf{R}$ & $\mathbf{K}$ & $\mathbf{P}$ & $\mathbf{L S}$ & $\mathbf{A}$ \\
\hline \hline 1 & 3200 & 0.032 & 1 & 9.41 & 963 \\
0.9 & 3200 & 0.032 & 1 & 9.41 & 867 \\
0.85 & 3200 & 0.032 & 1 & 9.41 & 819 \\
0.8 & 3200 & 0.032 & 1 & 9.41 & 771 \\
0.75 & 3200 & 0.032 & 1 & 9.41 & 723 \\
0.7 & 3200 & 0.032 & 1 & 9.41 & 674 \\
0.65 & 3200 & 0.032 & 1 & 9.41 & 626 \\
0.6 & 3200 & 0.032 & 1 & 9.41 & 578 \\
0.55 & 3200 & 0.032 & 1 & 9.41 & 530 \\
0.5 & 3200 & 0.032 & 1 & 9.41 & 482 \\
0.45 & 3200 & 0.032 & 1 & 9.41 & 434 \\
0.4 & 3200 & 0.032 & 1 & 9.41 & 385 \\
0.35 & 3200 & 0.032 & 1 & 9.41 & 337 \\
0.3 & 3200 & 0.032 & 1 & 9.41 & 289 \\
0.25 & 3200 & 0.032 & 1 & 9.41 & 241 \\
0.2 & 3200 & 0.032 & 1 & 9.41 & 193 \\
0.15 & 3200 & 0.032 & 1 & 9.41 & 145 \\
0.1 & 3200 & 0.032 & 1 & 9.41 & 96 \\
0.05 & 3200 & 0.032 & 1 & 9.41 & 48 \\
0.01 & 3200 & 0.032 & 1 & 9.41 & 10 \\
\hline
\end{tabular}

The excellent vegetative cover when $\mathrm{C}$ is equal to 0.01 yields an annual soil loss value of $10 \mathrm{Mg} / \mathrm{ha} / \mathrm{yr}$. This value still exceeds the sustainable soil loss rate of 9 $\mathrm{Mg} / \mathrm{ha} / \mathrm{yr}$ but would be an acceptable annual soil loss rate. Similarly, Table 4 illustrates the annual soil loss rate of a varied $\mathrm{C}$ factor on 4:1 side slopes. 
Table 4. Influence of vegetative cover management factor, $C$, on $A, 4: 1$ slope

\begin{tabular}{|cccccc|}
\hline $\mathbf{C}$ & $\mathbf{R}$ & $\mathbf{K}$ & $\mathbf{P}$ & $\mathbf{L S}$ & $\mathbf{A}$ \\
\hline \hline 1 & 3200 & 0.032 & 1 & 7.71 & 790 \\
0.9 & 3200 & 0.032 & 1 & 7.71 & 711 \\
0.85 & 3200 & 0.032 & 1 & 7.71 & 671 \\
0.8 & 3200 & 0.032 & 1 & 7.71 & 632 \\
0.75 & 3200 & 0.032 & 1 & 7.71 & 592 \\
0.7 & 3200 & 0.032 & 1 & 7.71 & 553 \\
0.65 & 3200 & 0.032 & 1 & 7.71 & 513 \\
0.6 & 3200 & 0.032 & 1 & 7.71 & 474 \\
0.55 & 3200 & 0.032 & 1 & 7.71 & 434 \\
0.5 & 3200 & 0.032 & 1 & 7.71 & 395 \\
0.45 & 3200 & 0.032 & 1 & 7.71 & 355 \\
0.4 & 3200 & 0.032 & 1 & 7.71 & 316 \\
0.35 & 3200 & 0.032 & 1 & 7.71 & 276 \\
0.3 & 3200 & 0.032 & 1 & 7.71 & 237 \\
0.25 & 3200 & 0.032 & 1 & 7.71 & 197 \\
0.2 & 3200 & 0.032 & 1 & 7.71 & 158 \\
0.15 & 3200 & 0.032 & 1 & 7.71 & 118 \\
0.1 & 3200 & 0.032 & 1 & 7.71 & 79 \\
0.05 & 3200 & 0.032 & 1 & 7.71 & 39 \\
0.01 & 3200 & 0.032 & 1 & 7.71 & 8 \\
\hline
\end{tabular}

Altering the embankment slope from 3:1 to 4:1 reduces the annual soil loss by 20 percent to $8 \mathrm{Mg} / \mathrm{ha} / \mathrm{yr}$. This value is within acceptable sustainable soil loss rates. Reduction of soil loss using cover management practice is achievable with 3:1 and 4:1 embankment slopes. The difficulty and cost in establishing and maintaining a vegetative cover management practice that is equivalent to $\mathrm{C}=0.01$ is high. Such vegetative coverage would be extremely difficult to maintain if the range is receiving a large volume of training activity. Visits to the four installations and the poor vegetative cover on many of the embankments leads to the conclusion that this goal is likely not attainable. Nonetheless, land managers should strive to develop a vegetative management plan that maximizes vegetative cover.

\section{Embankment Conservation Practices}

The remaining alternative is to change conservation practices, $\mathrm{P}$, on the embankment face and estimate the effect that this alteration has on annual soil loss values. The conservation practice most likely to be adopted on embankment faces is the installation of terraces on the embankment face that use grass waterways to divert water down the embankment edges. As an example we will revisit the previous example again and determine the annual embankment soil loss using one terrace and one grass waterway. This effectively halves the slope length and changes $\mathrm{P}$ from 1 to the following value: 
Conservation practice, P, (taken from ATTACC Handbook 1.1, Appendix F)

$$
P=P_{T} \times P_{G}=0.50 \times 0.65=0.325
$$

Slope length $=30.5$ meters.

The addition of a terrace to the embankment has the effect observed in Table 5.

Table 5. Influence of conservation practice, $P$, (terrace and grass waterway) on A, 3:1 slope.

\begin{tabular}{|cccccc|}
\hline $\mathbf{C}$ & $\mathbf{R}$ & $\mathbf{K}$ & $\mathbf{P}$ & $\mathbf{L S}$ & $\mathbf{A}$ \\
\hline \hline 1 & 3200 & 0.032 & 0.325 & 5.93 & 197 \\
0.9 & 3200 & 0.032 & 0.325 & 5.93 & 177 \\
0.85 & 3200 & 0.032 & 0.325 & 5.93 & 168 \\
0.8 & 3200 & 0.032 & 0.325 & 5.93 & 158 \\
0.75 & 3200 & 0.032 & 0.325 & 5.93 & 148 \\
0.7 & 3200 & 0.032 & 0.325 & 5.93 & 138 \\
0.65 & 3200 & 0.032 & 0.325 & 5.93 & 128 \\
0.6 & 3200 & 0.032 & 0.325 & 5.93 & 118 \\
0.55 & 3200 & 0.032 & 0.325 & 5.93 & 108 \\
0.5 & 3200 & 0.032 & 0.325 & 5.93 & 99 \\
0.45 & 3200 & 0.032 & 0.325 & 5.93 & 89 \\
0.4 & 3200 & 0.032 & 0.325 & 5.93 & 79 \\
0.35 & 3200 & 0.032 & 0.325 & 5.93 & 69 \\
0.3 & 3200 & 0.032 & 0.325 & 5.93 & 59 \\
0.25 & 3200 & 0.032 & 0.325 & 5.93 & 49 \\
0.2 & 3200 & 0.032 & 0.325 & 5.93 & 39 \\
0.15 & 3200 & 0.032 & 0.325 & 5.93 & 30 \\
0.1 & 3200 & 0.032 & 0.325 & 5.93 & 20 \\
0.05 & 3200 & 0.032 & 0.325 & 5.93 & 10 \\
0.01 & 3200 & 0.032 & 0.325 & 5.93 & 2 \\
\hline
\end{tabular}

The addition of a second terrace to the embankment has the effect observed in Table 6 ,

$$
P=P_{T} \times P_{G}=0.50 \times 0.65=0.325
$$

Slope length $=15$ meters. 
Table 6. Influence of conservation practice, $P$ (2 terraces, 1 waterway) on A, 3:1 slope.

\begin{tabular}{|cccccc|}
\hline $\mathbf{C}$ & $\mathbf{R}$ & $\mathbf{K}$ & $\mathbf{P}$ & $\mathbf{L S}$ & $\mathbf{A}$ \\
\hline \hline 1 & 3200 & 0.032 & 0.325 & 3.69 & 123 \\
0.9 & 3200 & 0.032 & 0.325 & 3.69 & 111 \\
0.85 & 3200 & 0.032 & 0.325 & 3.69 & 104 \\
0.8 & 3200 & 0.032 & 0.325 & 3.69 & 98 \\
0.75 & 3200 & 0.032 & 0.325 & 3.69 & 92 \\
0.7 & 3200 & 0.032 & 0.325 & 3.69 & 86 \\
0.65 & 3200 & 0.032 & 0.325 & 3.69 & 80 \\
0.6 & 3200 & 0.032 & 0.325 & 3.69 & 74 \\
0.55 & 3200 & 0.032 & 0.325 & 3.69 & 68 \\
0.5 & 3200 & 0.032 & 0.325 & 3.69 & 61 \\
0.45 & 3200 & 0.032 & 0.325 & 3.69 & 55 \\
0.4 & 3200 & 0.032 & 0.325 & 3.69 & 49 \\
0.35 & 3200 & 0.032 & 0.325 & 3.69 & 43 \\
0.3 & 3200 & 0.032 & 0.325 & 3.69 & 37 \\
0.25 & 3200 & 0.032 & 0.325 & 3.69 & 31 \\
0.2 & 3200 & 0.032 & 0.325 & 3.69 & 25 \\
0.15 & 3200 & 0.032 & 0.325 & 3.69 & 18 \\
0.1 & 3200 & 0.032 & 0.325 & 3.69 & 12 \\
0.05 & 3200 & 0.032 & 0.325 & 3.69 & 6 \\
0.01 & 3200 & 0.032 & 0.325 & 3.69 & 1 \\
\hline
\end{tabular}

It is obvious that the addition of terraces and the shortening of the embankment slope length are highly beneficial in reducing annual soil loss. Based on this information, the use of soil conservation practices is recommended. The remaining determinants are the calculation of optimum dimensional embankment parameters and estimation of maintenance intervals for an embankment structure. The following sections outline these procedures.

\section{Embankment Height, Slope, and Slope Length}

The calculations performed thus far have illustrated the importance of establishing vegetative cover and implementing conservation practices on a moving target emplacement. Additionally, the effects of slope and slope length have been investigated and their effects on annual soil loss observed. The determination of the optimum combinations of embankment slope, height, and slope length depends on many factors that will vary from range to range and within range areas. Therefore, a generalized design methodology using the Universal Soil Loss Equation (USLE) is presented to accommodate the variations inherent in such an approach. Again we look to the moving embankment on the MPTR (Range 37) at Camp Atterbury, IN.

Step 1: Determine a range of acceptable vegetative coverage factors ( 1 is bare soil, 0 is 100 percent ground cover) for the range structure to be designed or modified. 
Step 2: Determine embankment height based on line-of-sight requirements. Determine embankment thickness based on the RETS Range Design Manual.

Step 3: Determine LS factor. If the range structure is to be rehabilitated use the existing slope or if the range structure is to be constructed use the slope most suitable to the area topography (3:1 or $4: 1)$.

Step 4: Using the Universal Soil Loss equation, USLE, find the values of A based on LS and C factors.

Step 5: Determine maximum allowable berm height (slope length) based on A.

Step 6: Introduce conservation practices until chosen slope length reduces A to acceptable level.

Using the armor moving target embankment examined previously, the steps are as follows:

Step 1: Vegetative Cover Factor (select a range).

Field estimates of soil erosion at the study plot found the estimated coverage for the embankment to be 43 percent. This corresponded to a C-factor value of approximately 0.7 . This value will serve as the bottom range value. A C-factor value of .01 will serve as the top range value and is equivalent to vegetative cover of 95 percent. As part of this determination, the range manager must decide on a minimum acceptable level of vegetation. For this example, 80 percent vegetative cover or better is recommended on the embankment using short grasses.

Step 2: Determine initial embankment dimensional parameters.

Embankment height for the armor moving target structure was found to be 18 meters from the toe of the embankment. The structure was erected in an area of high relief and is representative of the upper range of embankment heights. The average slope length for the embankment was calculated to be 60 meters.

Additionally a 4:1 slope modification will be investigated. Embankment height will remain at 18 meters. The slope length will increase to 74 meters based on slope angle and berm height.

Step 3: LS factor.

The LS factor is based on slope length of 60 meters and slope angle 3:1 (33 percent).

$\mathrm{LS}=9.3$. 
The LS factor based on a slope length of 73 meters and a slope angle of $4: 1$ (25 percent).

$\mathrm{LS}=7.7$

Step 4: Use the USLE to find A.

Determine the annual soil loss from an embankment design. Based on the following criteria a suitable embankment design will be selected.

Step 5: Determine maximum allowable berm height.

Eighty percent or more vegetative cover, 3:1 or 4:1 side slopes. Additionally, the land manager must select the proper embankment slope given line-of-sight and topographical limitations. The annual soil loss was determined for the embankment for 3:1 and 4:1, conservation practices ( 1 terrace/ 1 waterway and 2 terraces/ 1 waterway) and no conservation practices. Table 7 illustrates the acceptable embankment configurations that most closely match the designated soil loss criteria.

Table 7. Embankment design criteria

\begin{tabular}{|cccccccccc|}
\hline Slope & Terraces & $\mathbf{C}$ & $\mathbf{R}$ & $\mathbf{K}$ & $\mathbf{P}$ & $\mathbf{L S}$ & $\mathbf{A}$ & $\mathbf{A} / \mathbf{T}$ & \% Veg \\
\hline \hline $\mathbf{3 : 1}$ & No & 0.01 & 3200 & 0.032 & 1 & 9.41 & 10 & 1.07 & 95 \\
$\mathbf{4 : 1}$ & No & 0.01 & 3200 & 0.032 & 1 & 7.70 & 8 & 0.88 & 95 \\
$\mathbf{3 : 1}$ & $\mathbf{1}$ & 0.05 & 3200 & 0.032 & 0.325 & 5.93 & 10 & 1.10 & 88 \\
$\mathbf{3 : 1}$ & $\mathbf{1}$ & 0.01 & 3200 & 0.032 & 0.325 & 5.93 & 2 & 0.22 & 95 \\
$\mathbf{4 : 1}$ & $\mathbf{1}$ & 0.1 & 3200 & 0.032 & 0.325 & 4.95 & 16 & 1.83 & 80 \\
$\mathbf{4 : 1}$ & $\mathbf{1}$ & 0.05 & 3200 & 0.032 & 0.325 & 4.95 & 8 & 0.92 & 88 \\
$\mathbf{4 : 1}$ & $\mathbf{1}$ & 0.01 & 3200 & 0.032 & 0.325 & 4.95 & 2 & 0.18 & 95 \\
$\mathbf{3 : 1}$ & $\mathbf{2}$ & 0.1 & 3200 & 0.032 & 0.325 & 4.52 & 15 & 1.67 & 80 \\
$\mathbf{3 : 1}$ & $\mathbf{2}$ & 0.05 & 3200 & 0.032 & 0.325 & 4.52 & 8 & 0.83 & 88 \\
$\mathbf{3 : 1}$ & $\mathbf{2}$ & 0.01 & 3200 & 0.032 & 0.325 & 4.52 & 2 & 0.17 & 95 \\
$\mathbf{4 : 1}$ & $\mathbf{2}$ & 0.1 & 3200 & 0.032 & 0.325 & 3.79 & 13 & 1.40 & 80 \\
$\mathbf{4 : 1}$ & $\mathbf{2}$ & 0.05 & 3200 & 0.032 & 0.325 & 3.79 & 6 & 0.70 & 88 \\
$\mathbf{4 : 1}$ & $\mathbf{2}$ & 0.01 & 3200 & 0.032 & 0.325 & 3.79 & 1 & 0.14 & 95 \\
\hline
\end{tabular}

Step 6:Reduce slope length etc. until acceptable annual soil loss is found.

The lowest cost design that meets sustainable range criteria is an embankment that has 3:1 side slopes, 2 terraces, and 1 grass waterway. The annual soil loss is 83 percent of the maximum allowable annual soil loss and the vegetative cover is above the minimum 80 percent. The embankment will require maintenance when the ratio of estimated soil loss/allowable soil loss exceeds 1 . The next section discusses the maintenance interval determination for the embankment design. 


\section{Embankment Maintenance Interval}

Information on the useful life and maintenance intervals of a range structure is critical to installation land managers in the development of long-term range maintenance schedules. Currently the Army has adopted the Army Training and Testing Area Carrying Capacity (ATTACC) model to estimate the effects that military training has on the land. The unit of measurement that has been chosen to estimate the carrying capacity of a training area is the Manuever Impact Mile (MIM). According to the ATTACC Handbook 1.1, a MIM is a conceptual unit of measure for military training representing the impact of training on training land in regard to vegetation loss (USAEC 1999). The MIM is based on the environmental impact of an M1A2 driving 1 mile. The severity of the impact will vary depending on where the training occurs. Various MIM multipliers exist to assist in determining training land impact depending on soil moisture content, soil type, and land condition. However, embankment erosion is not an estimable factor using the ATTACC model. To be able to do this would require further investigation on embankment degradation and the corresponding relationship to MIM values.

The useful life of a range structure is measured by the length of time that an emplacement can withstand the impacts of military training until erosion or vegetation removal reduces the training effectiveness of the structure or exposes the underlying superstructure.

Based on the dimensional characteristics specified in the RETS Range Design Manual, the embankment top portion can withstand $76 \mathrm{~mm}$ of soil loss before the embankment superstructure is exposed. The embankment life expectancy can be determined using Equation 4. As mentioned previously, using the values from the 1year and 30-year WEPP simulations to determine annual soil loss, the useful embankment life was estimated to range from 2.1 years $\left(\mathrm{S}=0.076 \mathrm{~m}, \rho b=1.45 \mathrm{Mg} / \mathrm{m}^{3}\right.$, $\mathrm{A}=253 \mathrm{Mg} / \mathrm{ha} / \mathrm{yr})$ to 4.4 years $\left(\mathrm{S}=0.076 \mathrm{~m}, \rho \mathrm{b}=1.45 \mathrm{Mg} / \mathrm{m}^{3}, \mathrm{~A}=510 \mathrm{Mg} / \mathrm{ha} / \mathrm{yr}\right)$, respectively. The embankment life under sustainable soil loss is quite large at 135 years. Indeed, using soil loss rates range from $6 \mathrm{Mg} / \mathrm{ha} /$ year to $11 \mathrm{Mg} / \mathrm{ha} /$ year for soil bulk densities of $1.6 \mathrm{Mg} / \mathrm{m}^{3}$, useful embankment life ranges from 200 to 100 years, respectively. However, this equation takes into account only uniform soil loss. The useful embankment life equation does not consider localized area soil loss that may occur due to localized training damage and thus Equation 4 should be applied with caution. Annual preventative maintenance is required to repair localized embankment damage (topsoiling, reseeding, soil stabilization). 


\section{Embankment Composition}

\section{Moving Target Embankments}

Moving target embankments on military ranges are the largest structures on a range. The embankment height, slope angle, and slope length present challenges to range managers to keep the embankments in acceptable condition to provide an emplacement that is an effective training structure to military training personnel.

Currently, moving target emplacement specifications dictate that the standard embankment slope not exceed 33 percent (3:1). Additionally, slopes less than 33 percent require a soil physical analysis to justify their use. This specification, is somewhat limiting as it treats the embankment as a homogeneous material whereas in reality it is a stratified matrix with a core layer and a capping layer. Based on information presented here, the design specifications must reflect this situation. More accurately, embankment slopes should not be less than 25 percent (4:1) or greater than 33 percent (3:1). Additionally, the slope length of the embankment face must be reduced to limit the runoff distance such that the estimated embankment soil loss does not exceed sustainable soil loss rates of the soil type or the maximum permissible velocity of the embankment vegetation.. The desired effect can be accomplished using erosion control structures (terraces, wattles, etc.). Moreover, embankment designs should separate surface and subsurface compaction requirements. The specifications in use properly achieve embankment stability for the subsurface composition at compaction levels of 90 to 95 percent laboratory maximum dry density. However, embankment face topsoil requirements are not specified and should be detailed. Surface composition shall consist of a layer of topsoil ranging in depth from 0.3 meters to 0.6 meters and be compacted to sufficient strength to withstand erosion but not suppress vegetative growth $(<1.4 \mathrm{MPa}$ penetrometer resistance.)

\section{Stationary Target Embankments}

Stationary target embankments possess the same limitations that moving target embankments possess. Currently, stationary target emplacement specifications dictate that the standard embankment slope not exceed 33 percent (3:1). Additionally, slopes less than 33 percent require a soil physical analysis to justify their use. This specification, is somewhat limiting as it treats the embankment as a homogeneous material whereas in reality it is a stratified matrix with a core layer and a capping layer. Based on the information presented here, the design specifications must reflect this situation. More accurately, embankment slopes should not be less than 20 percent (5:1) or greater than 33 percent (3:1). A 5:1 slope increases slope length approximately 60 percent compared to a 3:1 slope. However, the slope length increase 
is offset by a 22 percent reduction in runoff velocity. Thus, the slope length of the embankment face must be reduced to limit the runoff distance such that the estimated embankment soil loss does not exceed sustainable soil loss rates for the soil type or the maximum permissible velocity of the embankment vegetation. The desired effect can be accomplished using erosion control structures (terraces, wattles, etc.). Moreover, stationary target embankment designs should separate surface and subsurface compaction requirements. The specifications in use properly achieve embankment stability for the subsurface composition at compaction levels of 90 to 95 percent laboratory maximum dry density. However, embankment face topsoil requirements are not specified and should be detailed. Surface composition shall consist of a layer of topsoil ranging in depth from 0.3 meters to 0.6 meters and be compacted to sufficient strength to withstand erosion but not suppress vegetative growth $(<1.4 \mathrm{MPa}$ penetrometer resistance.) The stationary target side embankment requirements should remain at 3:1. A 5:1 front embankment face slope will more adequately handle training impact from weapons fire. The elongated slope will blend more with the surrounding environment creating a more effective training tool.

\section{Defilade Embankments}

As with stationary and moving target emplacements, firing emplacements require design modifications. The current design excessively uses rock riprap. Replacing the rock riprap with a geo-stabilized vegetated soil is the most feasible design scenario. The use of rock riprap should be modified to match the blast wave profile of the largest weapon used at the emplacement. Furthermore, alternatives to the current blast mat design should be explored. Embankment designs should separate surface and subsurface compaction requirements. The specifications in use properly achieve embankment stability for the subsurface composition at compaction levels of 90 to 95 percent laboratory maximum dry density. However, geo-stabilized side embankment topsoil requirements are not specified and should be detailed. Surface composition shall consist of a layer of topsoil ranging in depth from 0.3 meters to 0.4 meters and be compacted to sufficient strength to withstand erosion but not suppress vegetative growth $(<1.4 \mathrm{MPa}$ penetrometer resistance.) 


\section{Conclusion}

The development of sustainable range structures and sustainable ranges in general requires a high level of familiarity with the behavior and physical properties of the range parent soil. Previous design guidelines have established sound principles for the subsurface development of range structures and their stability and only minor modifications have been suggested in this area. However, little regard has been given to the near-surface requirements of range structures for erosion mitigation and extended embankment life. The issues discussed in this report and the methodology proposed for extended range life have addressed the near-surface stability problems of range embankments found in temperate climates.

Visits to several military training facilities identified typical problems encountered at most temperate climate installations. Five overarching issues were identified that commonly contribute to excessive range erosion. (1) Severe erosion was concentrated in highly localized areas in general regions of activity. (2) Improper range structure siting lead to an increase in construction and maintenance costs. (3) Standard range structures did not address erosion problems adequately. (4) Many range structures deviated from the standard design in an attempt to address erosion and maintenance issues. (5) The majority of erosion control structures on ranges were implemented after erosion problems occurred and were not preventative in nature. Chapter 2 explains these issues in more detail.

An analysis of the standard designs was conducted to examine the potential for incorporating soil conservation and erosion control measures into the general design framework. Based on this information and the discussions presented throughout this report several design approaches should be considered. The design guidelines should more adequately incorporate erosion control structures and soil conservation measures. Additionally, designs should include innovative techniques to solve soil loss problems that reduce construction costs and/or are easier to maintain over longer training intervals. Furthermore, the range structure should be reevaluated to minimize the embankment profile, support native vegetation as concealment, blend with the natural topography, and reduce construction and maintenance disturbances. Particular emphasis should be placed on evaluating the range superstructure to achieve gains in this area. Detailed recommendations are outlined at the end of Chapter 3 and specific modifications are presented in Chapter 5. 


\section{References}

Arns, F.S., M.J. Mitchell, F.C. Watts, and B.L. Wilson. 1979. Soil Survey of Hardin and Larue Counties, Kentucky. Soil Conservation Service, U. S. Department of Agriculture, Washington, DC.]

ASAE. 1999a. Soil cone penetrometer compaction (S313.3 FEB99). St. Joseph, Michigan: American Society of Agricultural Engineers.

ASAE. 1999b. Procedures for using and reporting data obtained with a soil cone penetrometer (EP542 FEB99). St. Joseph, Michigan: American Society of Agricultural Engineers.

ASTM D4318-00. 2005. Standard test methods for liquid limit, plastic limit, and plasticity index of soils. West Conshohocken, Pennsylvania: American Society for Testing and Materials International.

Flanagan, D.C., J.C. Ascough II, A.D. Nicks, M.A. Nearing, and J.M. Laflen. 1995. "Chapter 1. Overview of the WEPP erosion predicition model." USDA-Water Erosion Prediction Project Hillslope Profile and Watershed Model Documentation. NSERL Report \#10, July 1995 Retrieved on 25 May 2005 from: http://topsoil.nserl.purdue.edu/nserlweb/weppmain/docs/readme.htm

Food and Agricultural Organization (FAO). 1997. Field measurement of soil runoff and erosion Bulletin 68. Rome, Italy: United Nations Food and Agricultural Organization.

Foster, G.R. and L.D. Meyer. 1972. "A closed-form soil erosion equation for upland areas" in Sedimentation: Symposium to Honor H.A. Einstein. H.W. Shen (ed.), pp. 12.1-12.19. Fort Collins, Colorado.

Haigh, M.J. 1977. "The use of erosion pins in the study of slope evolution" in Shorter Technical Methods (II), Technical Bulletin No. 18, British Geomorphical Research Group. Norwich, U.K.: Geo Books.

Indiana Business Research Center. 2000. STATS Indiana: Indiana University Kelley School of Business, retrieved 26 May 2005 from: http://www.stats.indiana.edu/profiles/pr18081.html and http://www.stats.indiana.edu/profiles/pr18005.html

Lamari, L. 2002. ASSESS, image analysis software for plant disease quantification. American Phytopathological Society Press: St Paul, MN.

Lane, L.J., G.R. Foster, and A.D. Nicks. 1987. Use of fundamental erosion mechanics in erosion prediction. Paper No. 87-2540, ASAE, St. Joseph, Michigan. 
Liebnow, A.M., W.J. Elliot, J.M. Laflen, and K.D. Kohl. 1990. "Interrill erodibility: collection and analysis of data from cropland soils." Transactions of the ASAE 33:1882-1888.

McCool D.K., L.C. Brown, G.R. Foster, C.K. Mutchler, and L.D. Meyer. 1987. "Revised slope steepness factor for the universal soil loss equation." Transactions of the ASAE (30) 5:1387-1396.

McCool, D.K., G.R. Foster, C.K. Mutchler, and L.D. Meyer. 1989. "Revised slope length factor for the universal soil loss equation." Transactions of the ASAE. 32, 1571-1576.

Martin, T.T. 1996. "Evaluation of the WEPP model for predicting soil erosion from military training lands at Fort Riley, Kansas.” MS Thesis. Manhattan, Kansas: Kansas State University, Department of Agricultural and Biological Engineering.

Noble, R.A., R.C. Windgard, Jr., and T.R. Ziegler. 1990. Soil survey of Brown County and parts of Bartholomew County, Indiana. U.S. Department of Agriculture-Soil Conservation Service.

Office of the Secretary of Defense (OSD). 2003. Current and Future Training Requirements. Office of the Secretary of Defense Washington, DC. Retrieved 14 January 2005, from: http://permanent.access.gpo.gov/websites/dodandmilitaryejournals/www.denix.osd.mil/den ix/Public/News/OSD/i366/currentandfuturetrainingrequirements02.pdf.

Office of the Deputy Under Secretary of Defense (ODUSD). 2003. Department of Defense base structure report. Office of the Deputy Under Secretary of Defense for Installations and Environment Washington, DC. Retrieved 21 February 2005, from: http://www.defenselink.mil/news/Jun2003/basestructure2003.pdf

Risch, M.R. 2004. Chemical and biological quality of surface water at the U.S. Army Atterbury Reserve Forces Training Area near Edinburgh, Indiana, September 2000 through July 2001. Water-Resources Investigation Report 03-4149. U.S. Geological Survey, Indianapolis, Indiana.

Schnoebelen, D.J., J.M. Fenelon, N.T. Baker, J.D. Martin, E.R. Bayless, D.V. Jacques, and C.G. Crawford. 1999. Environmental setting and natural factors and human influences affecting water quality in the White River Basin, Indiana. U.S. Geological Survey WaterResources Investigations Report 97-4260.

Schwab, G.O., D.D. Fangmeier, W.J. Elliot, and R.K. Frevert. 1993. Soil and water conservation engineering, 4th edition. John Wiley \& Sons, Inc.

Technical Manual 5-818-1/Air Force Manual 88-3, Chapter 7, "Soils and Geology Procedures for Foundation Design of Buildings and Other Structures (Except Hydraulic Structures). Washington, D.C.: Joint Departments of the Army and Air Force.

U.S. Army Corps of Engineers (USACE). 1970. Engineer Manual (EM) EM-1110-2-1906. Laboratory soils testing. Washington, D.C.: U.S. Army Corps of Engineers.

CEHNC. 1998. RETS Range Design Manual. CEHNC 1110-1-23. U.S. Army Corps of Engineers - Engineering and Support Center Huntsville, Alabama. Available at: http://www.hnd.usace.army.mil/rtlp 
U.S. Army Environmental Center (USAEC). 1998. Prevention of Lead Migration and Erosion from Small Arms Ranges. SFIM-AEC-ET-TR-98033. USAEC, Range XXI Team, Aberdeen Proving Ground, MD and U.S. Army Training Support Center, Fort Eustis, Virginia. Available at: http://aec.army.mil/usaec/technology/leadmigration.pdf

USAEC (1999). Army Training and Testing Area Carrying Capacity (ATTACC) handbook for installations version 1.1. U.S. Army Environmental Center. Aberdeen Proving Ground, Maryland. March 1999. Retrieved on 21 May 2005 from: https://srp.army.mil/public/resources/resources.aspx.

U.S. Department of Agriculture-Natural Resources Conservation Service (USDA-NRCS). 2004 a. Soil Survey of Jefferson County, New York. NRCS Soil Data Mart. Washington, DC. Accessed on 14 January 2004. Available at: http://soildatamart.nrcs.usda.gov/

USDA-NRCS. 2004b. Soil Survey of Muskogee and Chattahoochee Counties, Georgia and Russell County, Alabama. NRCS Soil Data Mart. Washington, D.C. Accessed on 14 January 2004. Available at: http://soildatamart.nrcs.usda.gov/

Vachta, E. G. and Hutchinson, J. 1990. Pilot and expanded field testing of the erosion control management plan (ECMP) for army training lands: lessons learned (USACERL Technical Report N-91/04 December 1990). U. S. Army Corps of Engineers, Champaign, IL.

Watson, D.A. and J.M. Laflen. 1986. "Soil strength, slope, and rainfall intensity effects on interrill erosion." Transactions of the ASAE 29:98-102.

WEPP. 2005 WEPP Hillslope/watershed model windows interface. WEPP science version: February 24, 2005. West Lafayette, Indiana.: USDA-ARS-MWA, National Soil Erosion Research Laboratory.

Whittaker, O.J., and B.A. Waters. 1986. Soil survey of Bullitt and Spencer Counties, Kentucky. Soil Conservation Service, USDA, Washington, D.C.

Wischmeier, W.H. and D.D. Smith. 1978. Predicting Rainfall Erosion Losses-A Guide to Conservation Planning. USDA Handbook 537. GPO, Washington, DC. 


\section{Appendix A: Standard Range Designs for RETS Ranges}

The following range designs were taken from the RETS Range Design Manual website. The range structure and range layout designs presented in this appendix apply to those specific range designs referenced in the report. 


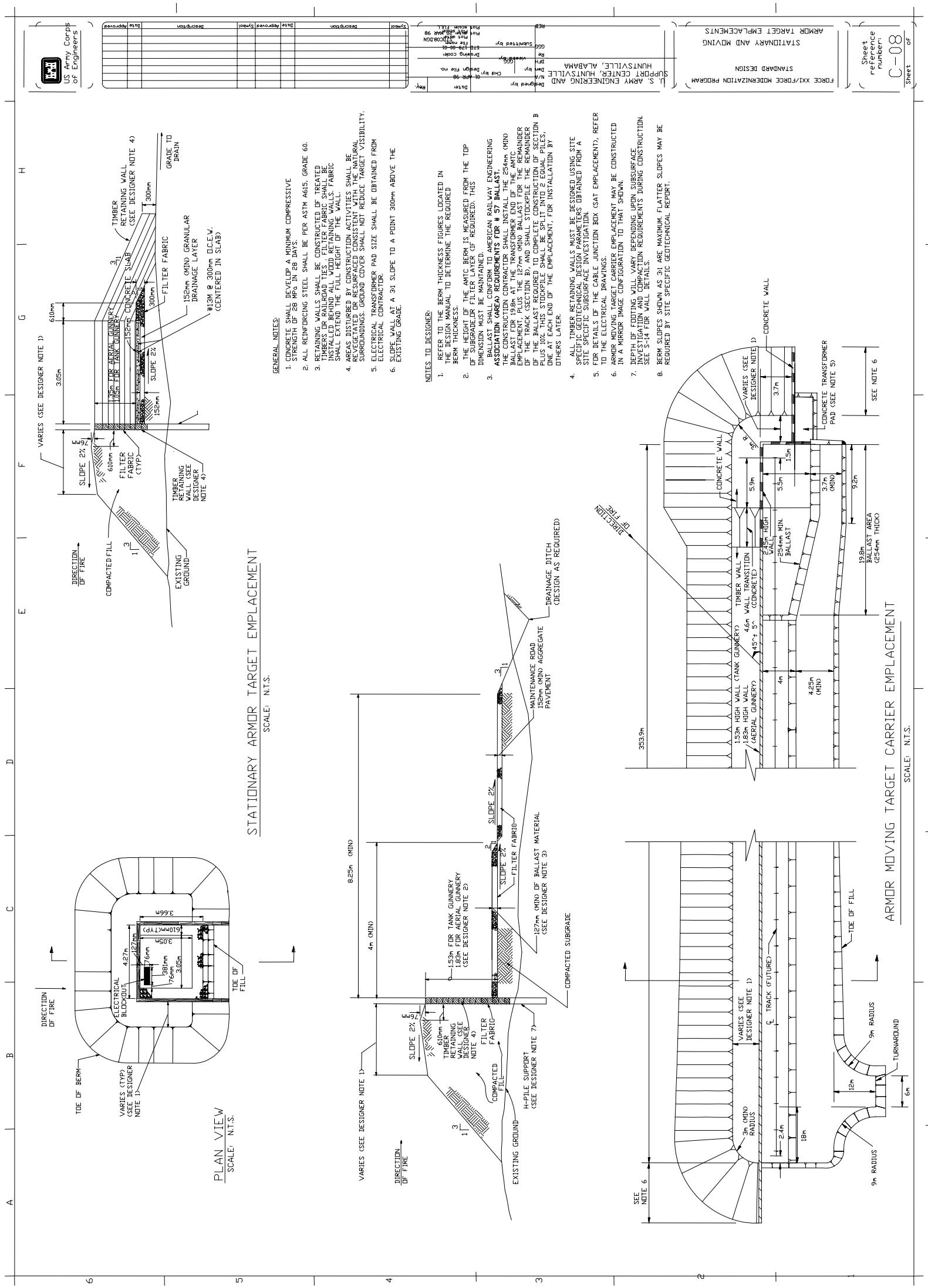

Figure A - 1. Stationary and moving target emplacement designs for armored vehicles. 


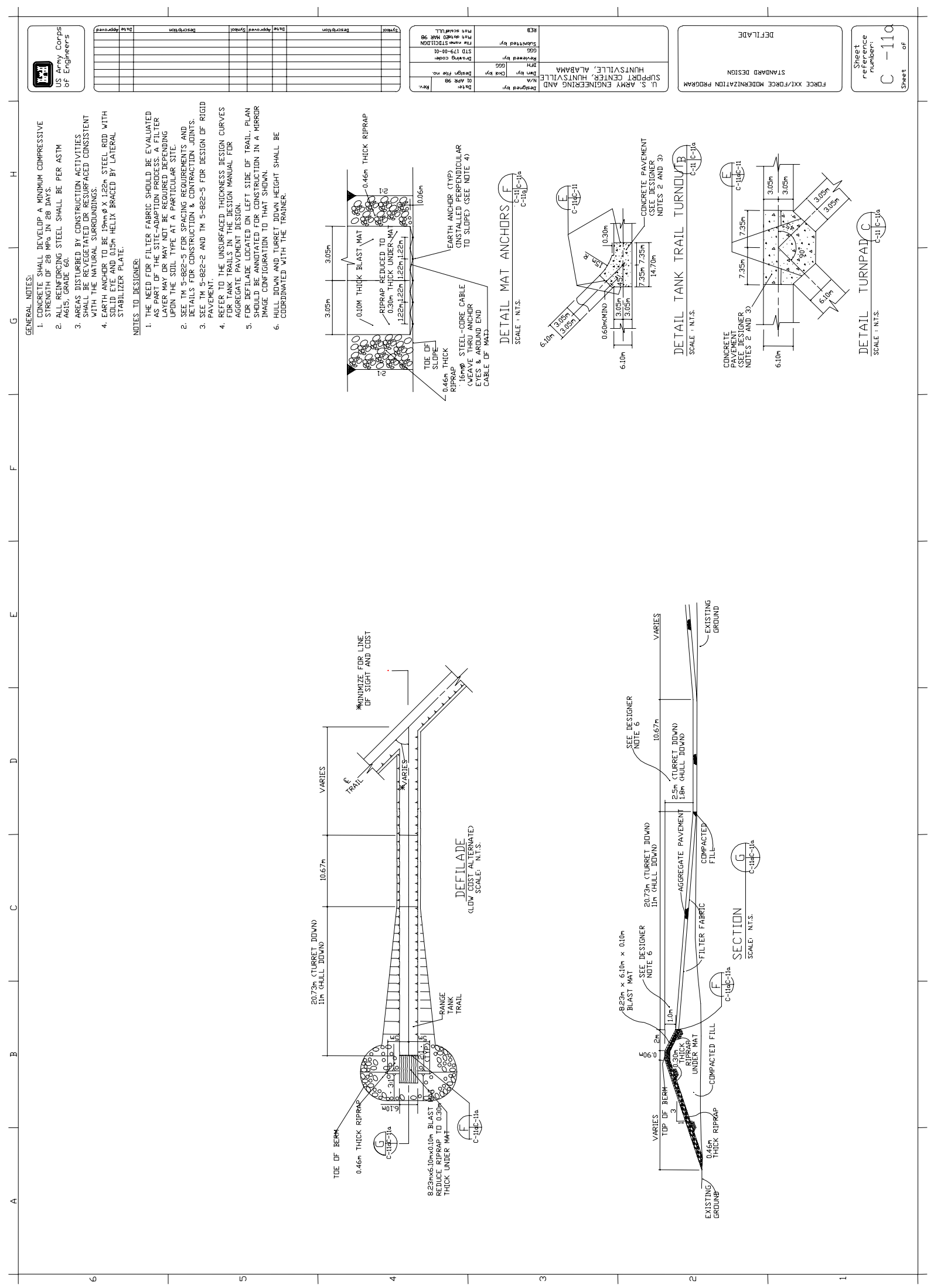

Figure A - 1.Low-cost defilade design for armored vehicles. 


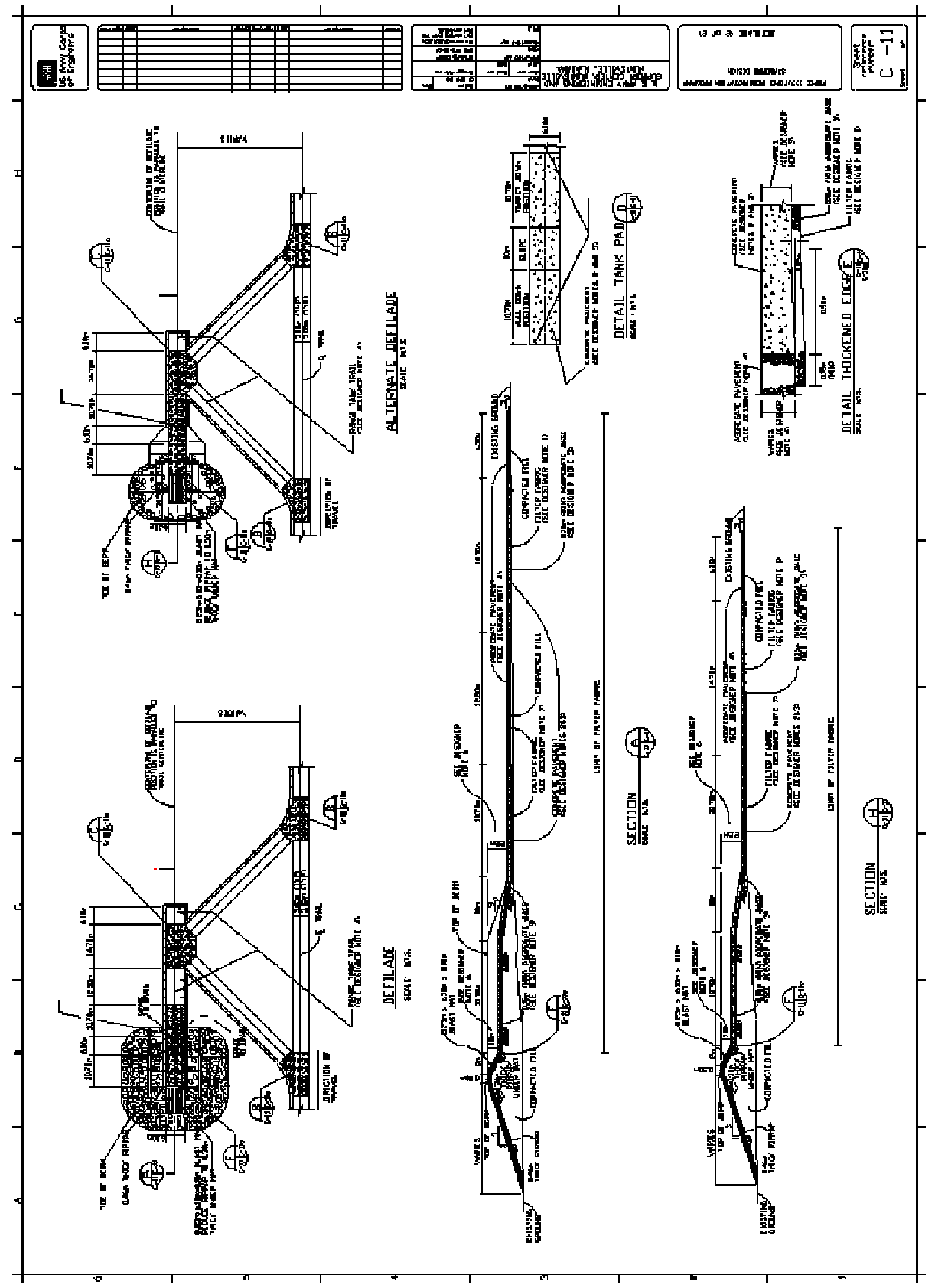

Figure A - 2. Standard defilade designs for armored vehicles. 


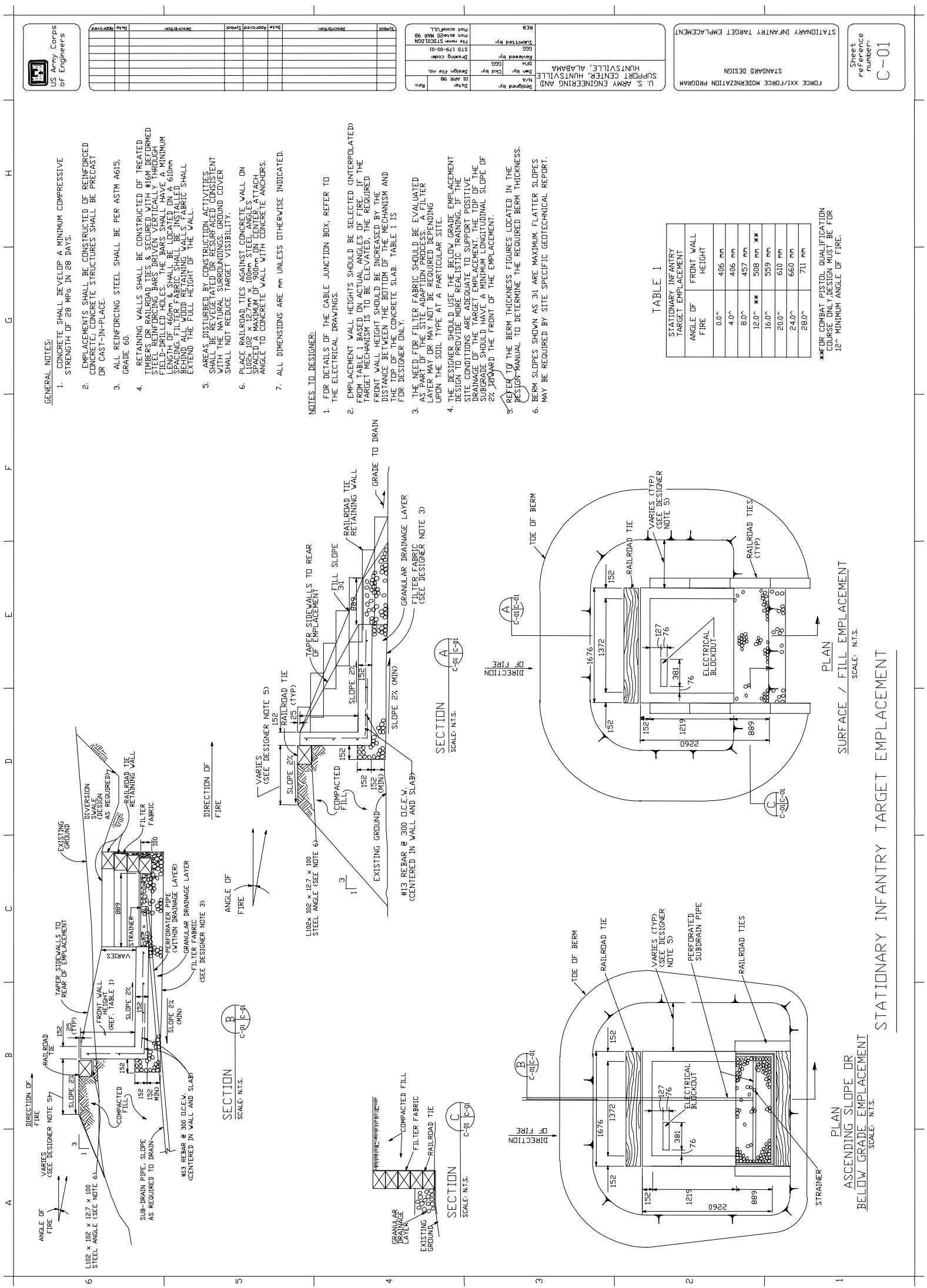

Figure A - 3. Stationary target design for infantry. 


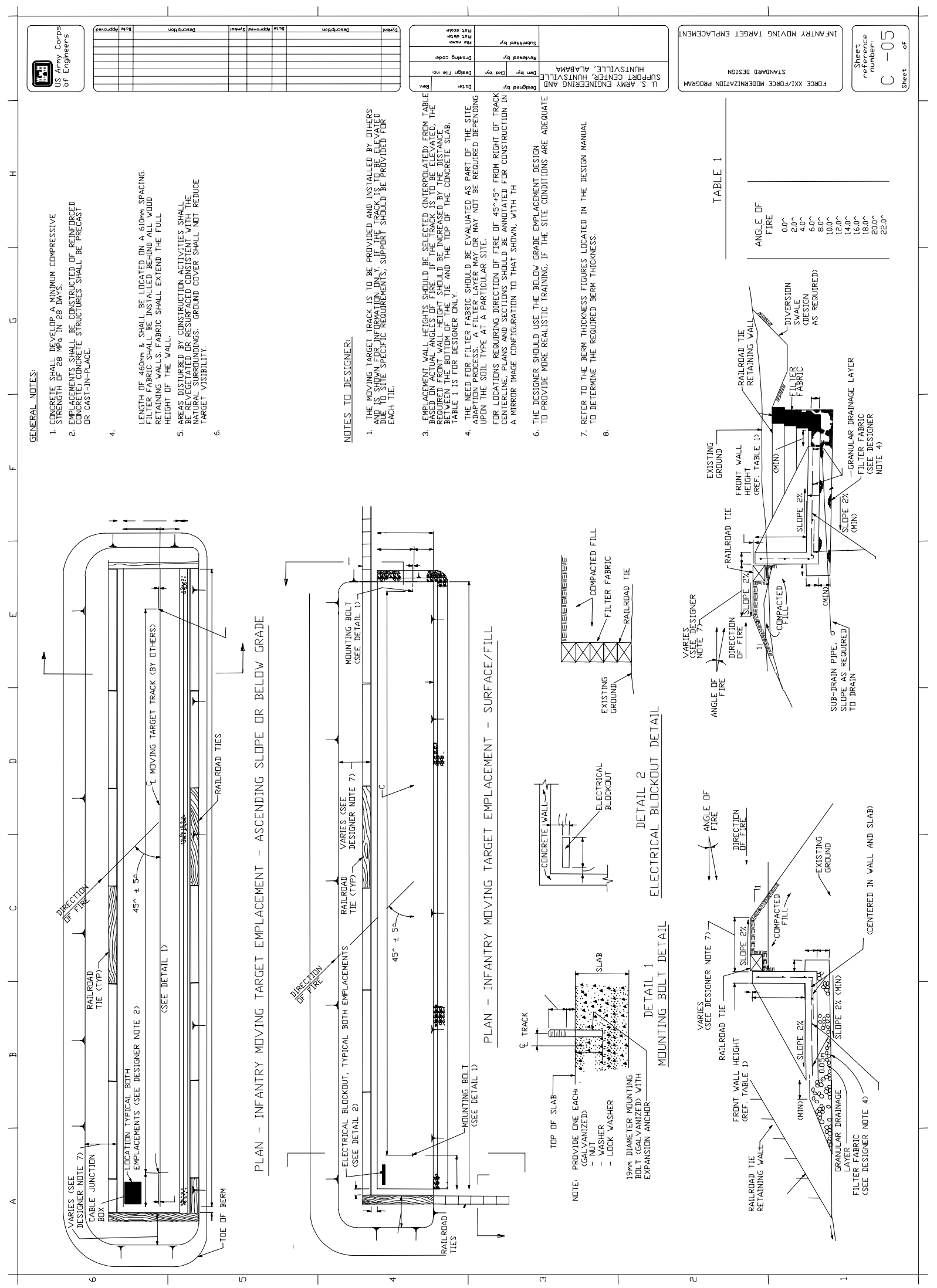

Figure A - 4. Moving target design for infantry. 


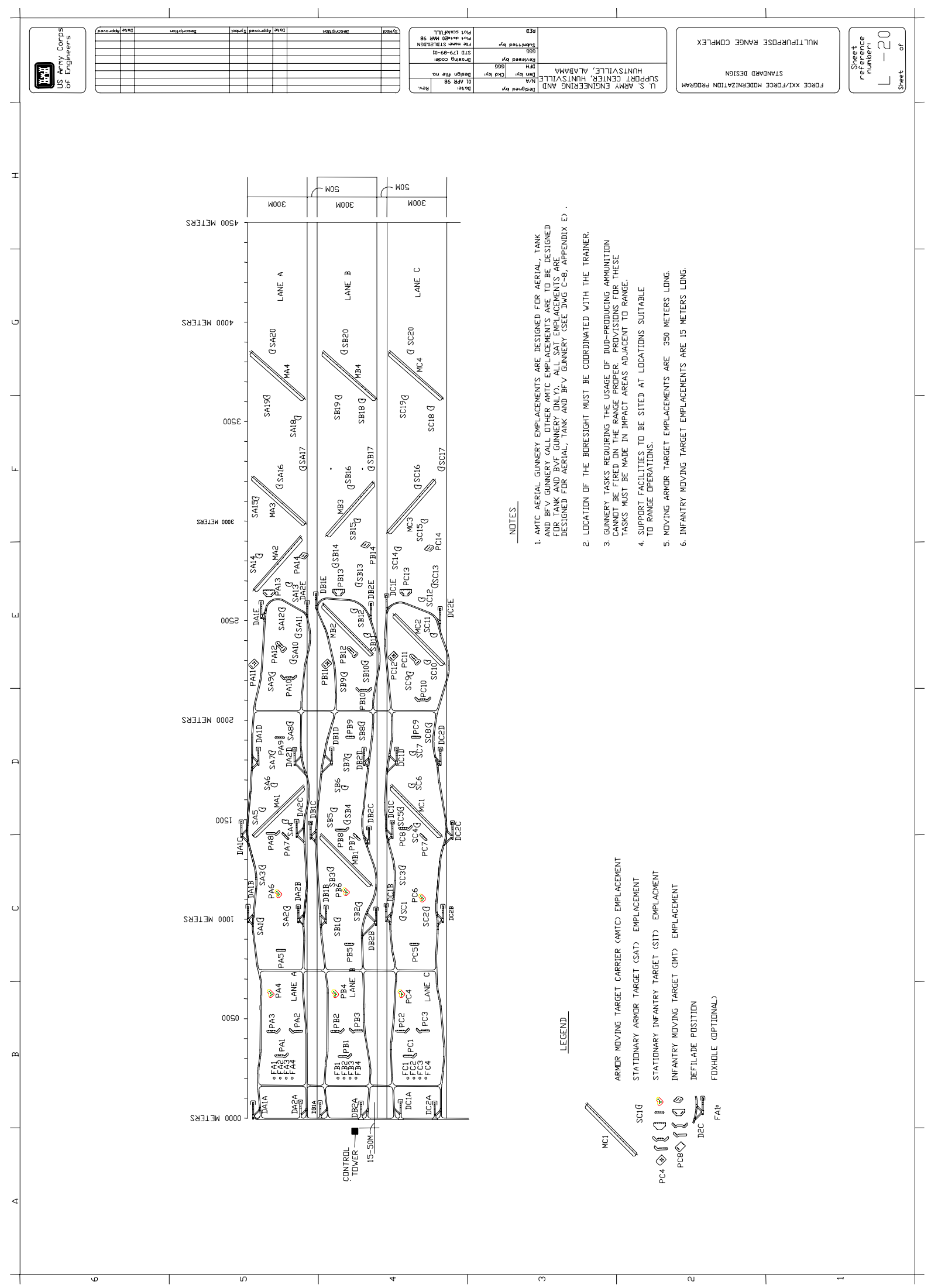

Figure A - 5. Multipurpose Range Complex (MPRC) design layout. 


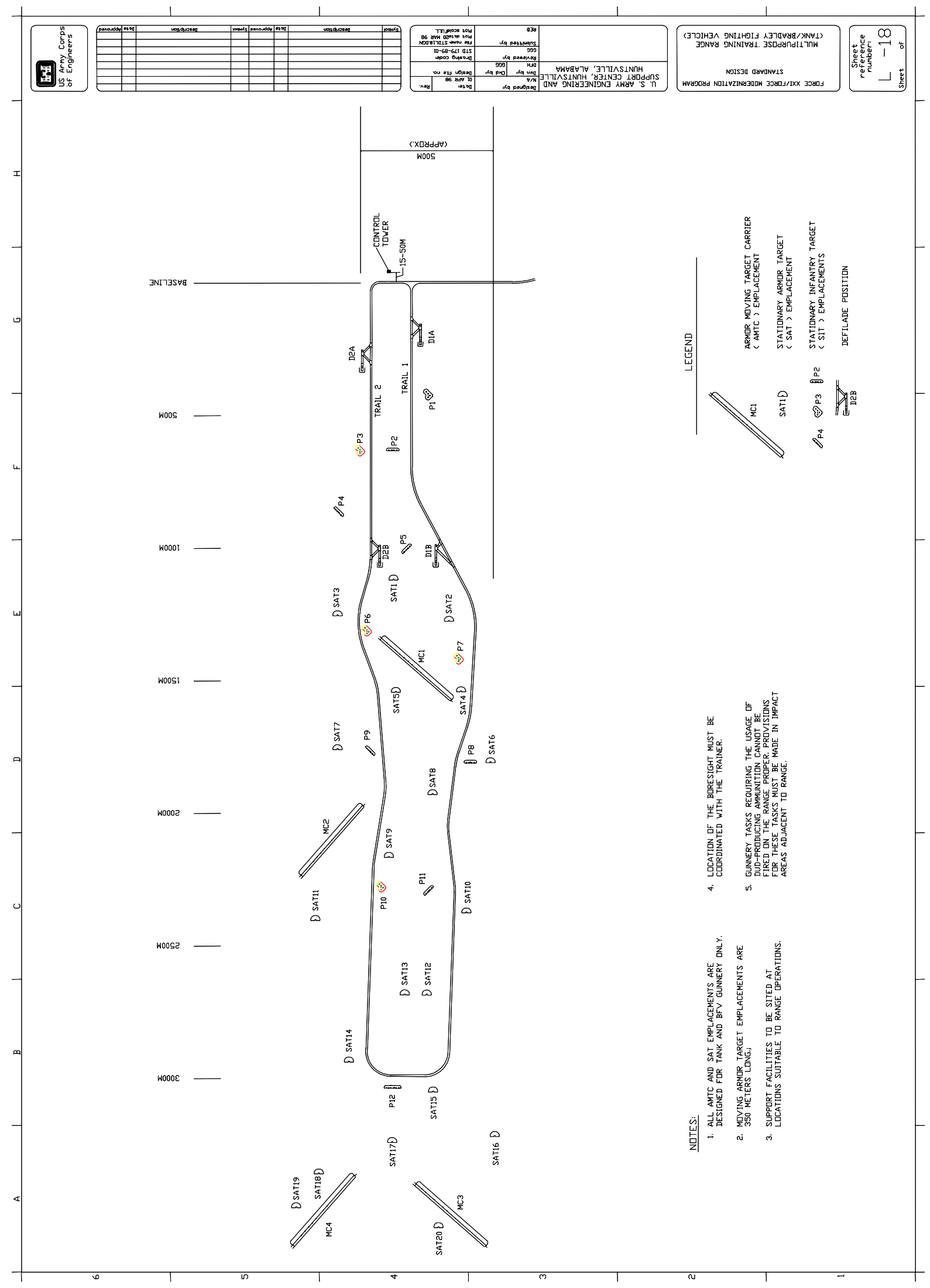

Figure A - 6. Multipurpose Training Range (MPTR) design layout. 


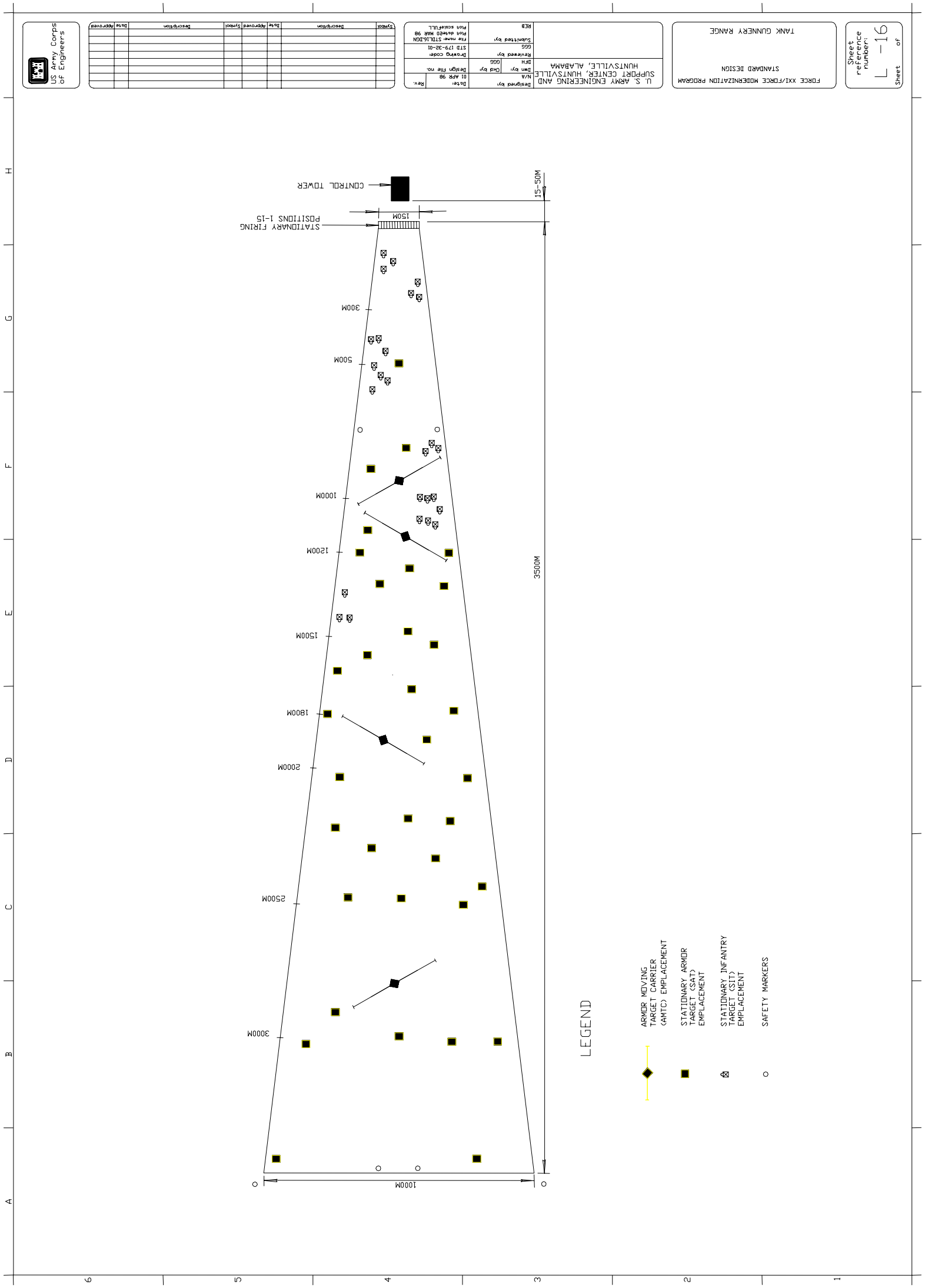

Figure A - 7. Tank gunnery range design layout. 


\section{Appendix B: Soil Data and Information at Camp Atterbury, Indiana}

The information presented in this appendix pertains to the soils of Camp Atterbury, Indiana. This information was obtained through detailed soil surveys of Brown County, Indiana and part of Bartholomew County, Indiana (Noble et al, 1990) and from the SSURGO database files downloaded for Brown County from the online NRCS Soil Data Mart website at http://soildatamart.nrcs.usda.gov/.

The predominant soil textural type for the range is silt loam with occasional areas of complex soils. However, the range designer should be familiar with all specific soil types as there is a great likelihood that range elements will be constructed upon or constructed with these soils.

Bean Blossom channery silt loam consists of deep, moderately well drained, moderately rapidly permeable soils on flood plains, alluvial fans and colluvial benches. These soils formed in very channery or extremely channery alluvium or colluvium. Slopes range from 1 to 3 percent. Soil areas range from 5 to 80 acres in size. Soil has a low available water capacity (AWC) and surface runoff is slow. Organic matter is moderately low.

Berks-Trevlac-Wellston complex associations are moderately deep and deep, moderately sloping to very steep, well-drained soils formed in loess and in material weathered from shale, siltstone, and sandstone; on uplands. Soil areas are large up to several thousand acres in size. The AWC is low-low-high respectively. The generally soil mixture is 45-20-20. Soil permeability ranges from moderately rapidly permeable to moderately permeable. Organic matter content is moderate for all three soil groups. Surface runoff is very rapid and the potential for erosion is high.

Bonnell loam consists of deep, well-drained, slowly permeable soils on uplands. These soils form in glacial till. Slopes range from 12 to 20 percent. Soil areas range from 10 to 60 acres in size. Bonnell soils are similar to Hickory soils and are commonly adjacent to Cincinnati soils. The AWC is high, soil permeability is slow and surface runoff is rapid. Soil strength is low with high shrinkage and swelling. The erosion potential is high and organic matter content is moderate. 
Bonnell clay loam soils are moderately steep, deep, well drained soil on narrow ridgetops and side slopes in the uplands. Soil areas range from 10 to 60 acres in size. These soils are often gullied and heavily eroded. Slopes range from 12 to 20 percent. The soil has a high AWC. The soil permeability is slow and runoff potential is rapid. Soil strength is low with a high shrinkage and swelling. Organic matter content is very low.

Cincinnati silt loam consists of deep, well-drained soils on uplands. These soils formed in loess and in the underlying glacial drift. They have a fragipan. Permeability is moderate above the fragipan and slow in the fragipan. Areas of Cincinnati silt loam are 5 to 60 acres in size. Soil AWC is moderate. Organic content in the soil is moderate and surface runoff is rapid. Soil strength is low and is frost susceptible. Slopes range from 6 to 12 percent.

Hickory silt loam soils consist of steep, deep, well-drained, moderately permeable soils on the side slopes on uplands. These soils formed in a thin mantle of loess and in the underlying glacial till. Slopes range from 12 to 70 percent. Most areas where this soil is present are woodlands. Areas of soil are generally 10 to 100 acres in size. Hickory soils have a high AWC and are moderately permeable. Surface runoff is rapid and the organic matter content is low. Soil strength is low and is frost susceptible.

Pekin silt loam soils consist of deep, moderately well drained soils on stream terraces. These soils form in silty and loamy alluvial deposits. Typical areas of soil are 5 to 15 acres in size. Pekin soils have a moderate AWC. Soil permeability is moderate above the fragipan and very slowly permeable in the fragipan. Surface runoff is medium and organic matter content is moderate. Soil strength is low and potential for frost damage is high.

Tilsit silt loam soils consist of deep, moderately well drained soils on the tops of ridges in the uplands. These soils formed in loess and in the underlying material weathered from interbedded siltstone, sandstone and shale. Land areas range from 5 to 50 acres in size. Soil AWC is moderate, permeability is moderate above the fragipan and slow in the fragipan. Surface runoff is medium and Organic matter content is moderate. Slopes range from 2 to 6 percent. This soil series is Pekin soils and is often adjacent to Gilpin, Trevlac and Wellston soils. Suseptibility to soil wetness is a limitation on construction for this soil.

Wellston-Gilpin silt loam soils consist of deep, steep, well-drained, moderately permeable soils on uplands. These soils formed in loess and in the underlying material weathered from interbedded siltstone, sandstone, and shale and soil areas are up to several thousand acres in size. Soil mixture is 50-35 respectively with the remain- 
ing 15 percent Tilsit and heavily eroded soils. Slopes range from 6 to 70 percent. The AWC is high is Wellston and low in Gilpin soils. Both soils are moderately permeable. Surface runoff is rapid and organic matter content is moderate. Slopes, depth to bedrock, frost susceptibility are limitations for construction on this soil.

Sustainable soil loss values for selected soils per year:

Be - Beanblossom channery silt loam $-6 \mathrm{Mg} / \mathrm{ha}$,

Bg F - Berks-Trevlac-Wellston complex - $6 \mathrm{Mg} / \mathrm{ha}$,

Hk F - Hickory silt loam - $11 \mathrm{Mg} / \mathrm{ha}$,

We C2 - Wellston-Gilpin silt loams - $9 \mathrm{Mg} / \mathrm{ha}$. 


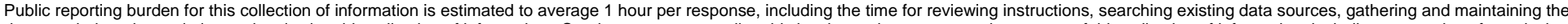

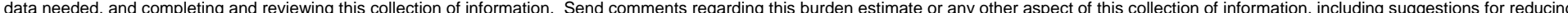

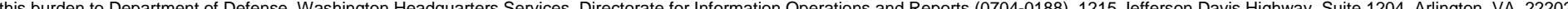

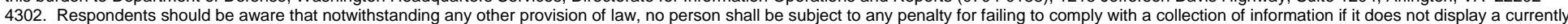
valid OMB control number. PLEASE DO NOT RETURN YOUR FORM TO THE ABOVE ADDRESS

\section{REPORT DATE (DD-MM-YYYY) 06-2006}

4. TITLE AND SUBTITLE

Evaluation of Soil Loss and Erosion Control Measures on Ranges and Range Structures at Installations in Temperate Climates
3. DATES COVERED (From - To)

5a. CONTRACT NUMBER

5b. GRANT NUMBER

5c. PROGRAM ELEMENT NUMBER

5d. PROJECT NUMBER

622720 A 896

5e. TASK NUMBER

5f. WORK UNIT NUMBER

F50G68

8. PERFORMING ORGANIZATION REPORT NUMBER

ERDC/CERL TR-06-14

U.S. Army Engineer Research and Development Center (ERDC)

Construction Engineering Research Laboratory (CERL)

PO Box 9005

Champaign, IL 61826-9005

\section{SPONSORING I MONITORING AGENCY NAME(S) AND ADDRESS(ES)}

Office of the Director of Environmental Programs

600 Army Pentagon

Washington, DC 20310-0600

10. SPONSOR/MONITOR'S ACRONYM(S)

DAIM-ED

11. SPONSOR/MONITOR'S REPORT NUMBER(S)

\section{DISTRIBUTION / AVAILABILITY STATEMENT}

Approved for public release; distribution is unlimited.

\section{SUPPLEMENTARY NOTES}

Copies are available from the National Technical Information Service, 5285 Port Royal Road, Springfield, VA 22161.

\section{ABSTRACT}

The Department of Defense operates the largest and most diverse training enterprise in the world. The Army has under its authority 1.3 million uniformed and civilian personnel at over 4100 locations using over 61 million square kilometers of land. Providing realistic and effective training is a key element in fulfilling the military mission. The sustainable use of military training lands presents a challenge to maintaining combat preparedness. Range managers need cost-effective long-term solutions that alleviate maintenance requirements and increase training intervals.

Guidelines on the design of small arms ranges to prevent erosion have been developed. However, these guidelines do not incorporate sustainable range elements into the overall design, and without proper soil and water conservation, large ranges have the potential to contribute greatly to overall installation erosion.

This research evaluates design weaknesses and develops an improved design methodology for embankments, firing points, and targeting impact positions on training ranges. Additionally recommendations are outlined that propose specific guidelines for range structures: defilades, stationary armor targets and moving armor targets that reduce soil loss and improve training realism.

\section{SUBJECT TERMS}

range management

ranges

\section{SECURITY CLASSIFICATION OF:}

\section{a. REPORT}

Unclassified

\section{b. ABSTRACT}

Unclassified training lands

erosion control

\section{c. THIS PAGE}

Unclassified

\begin{tabular}{l|l} 
17. LIMITATION & 18. \\
OF ABSTRACT & \\
SAR &
\end{tabular}

8. NUMBER OF PAGES

76 soil erosion

19a. NAME OF RESPONSIBLE PERSON Dick L. Gebhart

\section{9b. TELEPHONE NUMBER}

(include area code) (217) 352-6511, ext 7517

Standard Form 298 (Rev. 8-98)

Prescribed by ANSI Std. 239.18 